\title{
Systematics and convergent evolution of multiple reef-associated Jurassic and Cretaceous crabs (Decapoda, Brachyura)
}

\author{
Adiël A. Klompmaker, Natalia Starzyk, René H. B. Fraaije, and Günter Schweigert
}

\begin{abstract}
The Late Jurassic marks the first major radiation among true crabs (Brachyura) in reef environments, followed by another diversification in the mid- to Late Cretaceous in multiple habitats. We studied brachyuran carapaces from Mesozoic sponge- and coralassociated limestones in Europe. Six new taxa are described: Late Jurassic Europrosopon gen. nov., Eodromites bernchrisdomiorum sp. nov., Prosopon josephcollinsi sp. nov., Tanidromites nightwishorum sp. nov., and T. weinschenki sp. nov.; and midCretaceous Eodromites cristinarobinsae sp. nov. Furthermore, we recognize four junior synonyms: Eodromites grandis (=E. guenteri), Tanidromites scheffnerae (=T. wysokaensis), and Europrosopon aculeatum (=E. verrucosum and E. barbulescuae). Five taxa are reassigned: Eodromites aequilatus to Tanidromites, Tanidromites rotundus to Eodromites, Nodoprosopon dzhafarberdensis to ?Abyssophthalmus, Nodoprosopon from Nodoprosopidae to Homolodromiidae, and Rathbunopon from Glaessneropsidae to Prosopidae. Several other taxa are redescribed. The latter reassignment indicates that Rathbunopon does not represent an example of extreme convergent evolution as implied previously. Conversely, the frontal structure consisting of a rostrum with two diverging spines and outer orbital spines appears a remarkable example of convergent evolution of the goniodromitid Navarradromites toward members of Homolodromiidae, for which this frontal structure is characteristic. Rostral spines represent another example of convergent evolution. Some specimens are extraordinary: A specimen of Abyssophthalmus cf. A. spinosus represents the largest complete reported Jurassic brachyuran thus far and one specimen of Planoprosopon aff. P. hystricosus bears one of the largest known parasitic isopod-induced swellings (ichnotaxon Kanthyloma crusta) relative to carapace size. Overall, our results indicate that biodiversity and convergent evolution in Mesozoic brachyurans remain understudied.
\end{abstract}

http://zoobank.org/3A934459-9088-4AAB-8CAA-53787046FA17

Klompmaker, Adiël A., Starzyk, Natalia, Fraaije, René H. B., and Schweigert, Günter. 2020. Systematics and convergent evolution of multiple reef-associated Jurassic and Cretaceous crabs (Decapoda, Brachyura). Palaeontologia Electronica, 23(2):a32. https:// doi.org/10.26879/1045

palaeo-electronica.org/content/2020/3084-mesozoic-reef-crabs

Copyright: July 2020 Paleontological Society.

This is an open access article distributed under the terms of Attribution-NonCommercial-ShareAlike 4.0 International (CC BY-NC-SA 4.0), which permits users to copy and redistribute the material in any medium or format, provided it is not used for commercial purposes and the original author and source are credited, with indications if any changes are made.

creativecommons.org/licenses/by-nc-sa/4.0/ 
Adiël A. Klompmaker. Department of Museum Research and Collections \& Alabama Museum of Natural History, The University of Alabama, Box 870340, Tuscaloosa, Alabama 35487, USA; Department of Integrative Biology and Museum of Paleontology, University of California, Berkeley, 1005 Valley Life Sciences Building \#3140, Berkeley, California 94720, USA. adielklompmaker@gmail.com Natalia Starzyk. Institute of Systematics and Evolution of Animals, Polish Academy of Sciences, ul. Sławkowska 17, 31-016 Kraków, Poland. natalia_slaby@wp.pl

René H.B. Fraaije. Oertijdmuseum, Bosscheweg 80, NL-5283 WB Boxtel, The Netherlands. info@oertijdmuseum.nl Günter Schweigert. Staatliches Museum für Naturkunde, Rosenstein 1, 70191 Stuttgart, Germany. guenter.schweigert@smns-bw.de

Keywords: Arthropoda; biodiversity; convergence; Crustacea; Mesozoic; new genus; new species; reefs Submission: 18 November 2019. Acceptance: 18 June 2020.

\section{INTRODUCTION}

The systematics and phylogeny of various Mesozoic brachyuran clades have been debated and revised extensively in the last 15 years (e.g., Schweitzer and Feldmann, 2008a, 2009d; Karasawa et al., 2011, 2014; Van Bakel et al., 2012; Wolfe et al., 2019) and dozens of new species have been described (e.g., Schweitzer and Feldmann, 2009d; Schweigert and Koppka, 2011; Klompmaker, 2013a; Starzyk, 2016; Schweitzer et al., 2018, 2019; Nyborg et al., 2019). Research on trends in the biodiversity of brachyurans throughout the Mesozoic has also progressed (Klompmaker et al., 2013b; Schweitzer and Feldmann, 2015), and the positive influence of the presence of reefs for brachyuran diversity has been shown quantitatively (Klompmaker et al., 2013b). Although first-order patterns in the brachyuran biodiversity are unlikely to change substantially due to the large number of species described over the last two centuries, there is no indication that nearly all Mesozoic true crab species have been described (as also shown for fossil decapods, see Schweitzer and Feldmann, 2016).

A key aspect for an accurate phylogenetic framework for brachyurans is the correct recognition of morphological convergent evolution, which may obscure phylogenetic relationships between taxa if not identified. Such evolution is known from multiple invertebrates including crustaceans (Moore and Willmer, 1997; Tshudy et al., 2009; Pérez-Losada et al., 2009; Scholtz, 2014). Among decapods, an obvious example are pectinate chelae found in the Ctenochelidae Manning and Felder, 1991, Nephropidae Dana, 1852, and Polychelidae Wood-Mason, 1875 (Tshudy and Sorhannus, 2000), and similar chelae are apparently found in Erymidae Van Straelen, 1925, Stenochiri- dae Beurlen, 1928a, Leucosiidae Samouelle, 1819, and Iphiculidae Alcock, 1896 (Hyžný and Dulai, 2014). Some extant species of Sesarmidae Dana, 1851, and Grapsidae MacLeay, 1838, are tree-climbing crabs, and all possess relatively long propodi and short dactyli through convergent evolution (Fratini et al., 2005). Paddle-like distal elements are found on the $5^{\text {th }}$ pair of appendages in distantly related swimming crabs (Luque et al., 2019). Other examples of convergent evolution in modern decapods have been found in the mandibular palp of freshwater crabs (Daniels et al., 2006), the dactyli of hippoids and raninoids (Dixon et al., 2003), the reduced telsons and uropods in brachyurans and some anomurans (Dixon et al., 2003), and the chelae, gonopod, and carapace morphology of freshwater crayfish (Breinholt et al., 2012). Carcinization in certain Anomura (Porcellanidae Haworth, 1825 and Lithodidae Samouelle, 1819) and Palinurida (Scyllaridae Latreille, 1825) has led to brachyuran-like morphologies of the carapace and appendages (McLaughlin and Lemaitre, 1997; Scholtz, 2014; Luque et al., 2019). Some examples include fossil brachyurans. Carapacebased brachyuran species from the CretaceousPaleogene previously classified as Xanthosia Bell, 1863 (superfamily Etyoidea), have been referred to different superfamilies within Eubrachyura (Schweitzer et al., 2012a). The flattened, much wider than long carapace can be seen as an example of convergent evolution. Members of "Xanthosia" are thought to have had a swimming mode of life (Fraaye, 1996). Furthermore, the Cretaceous genera Palaeocorystes Bell, 1863 (junior synonym of Notopocorystes M'Coy, 1849) and Eucorystes Bell, 1863, were considered members of the eubrachyuran family Corystidae Samouelle, 1819, upon their erection based on the perceived close similarity of 
Palaeocorystes to modern Corystes cassivelaunus (Pennant, 1777). Both have a burrowing mode of life (e.g., Glaessner, 1980) and a longer than wide carapace generally. However, both Palaeocorystes and Eucorystes are representatives of Raninoida rather than Eubrachyura (Van Bakel et al., 2012; Karasawa et al., 2014). For Cenozoic brachyurans, some members of Pinnotheridae and Hexapodidae share small, pea-shaped carapaces. As a result, some hexapodid taxa were incorrectly assigned to pinnotherids (Luque et al., 2017, p. 15). Despite these examples, the commonness and the degree of convergence in fossil decapods remains an open question.

The main goals of this research are (1) to study the systematics and biodiversity of a variety of Mesozoic brachyurans from Europe, principally from reef habitats, by reassessing known and describing new taxa, and (2) assess convergent evolution within a number of these taxa.

\section{MATERIALS AND METHODS}

Starzyk (2013) introduced new terminology for morphological details of Tanidromites Schweitzer and Feldmann, 2008a, such as anterior grooves, hepatic pits, and hepatic tubercles. We do not use hepatic tubercles here and introduce "mesogastric groove tubercles" instead because the hepatic groove in which these hepatic tubercles can be seen is positioned between the protogastric and hepatic regions for brachyurans rather than delimiting the lateral parts of the posterior portion of the mesogastric region (e.g., Crônier and Boursicot, 2009, figure 2; Jagt et al., 2014). In many brachyurans, the hepatic region does not border the mesogastric region (e.g., Glaessner, 1969, figure 220; Davie et al., 2015, figure 71-2.6). Such mesogastric groove tubercles can be found on the internal mold and on the cuticle in representatives of Tanidromites (Starzyk, 2016, 2013; herein), but also in specimens of Distefania Checchia-Rispoli, 1917, Eodromites Patrulius, 1959, Gabriella Collins et al., 2006, and Pithonoton von Meyer, 1842.

Gastric pits have been used extensively to describe two pits on the gastric region close to the longitudinal axis of decapods (e.g., Jakobsen and Collins, 1997; Blow, 2003; Hyzný and Müller, 2010; Klompmaker et al., 2012), but cervical pits have been used instead recently (Starzyk, 2013, 2016; Robin et al., 2015; Hyžný et al., 2015). We here use gastric pits because not all such pits are located clearly within the cervical groove (e.g., Dakoticancridae; Nitotacarcinus Schweitzer et al., 2007; some Etyidae) or a clear cervical groove is

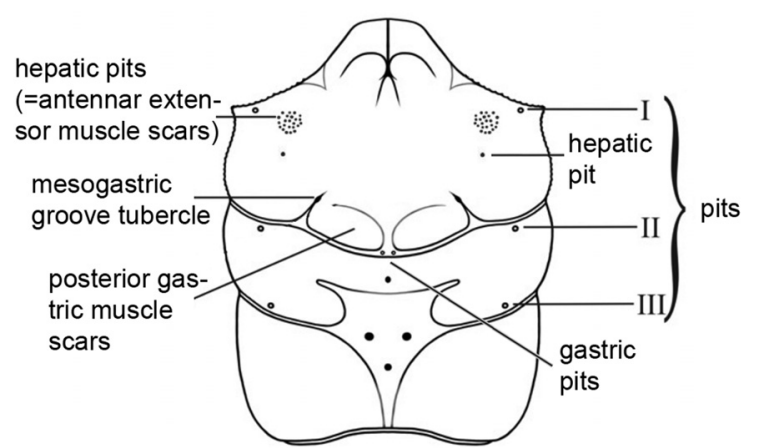

FIGURE 1. Pits and muscle scars present on the dorsal carapace of some brachyuran crabs and referred to in the manuscript, particularly for Tanidromites Schweitzer and Feldmann, 2008a, and Eodromites Patrulius, 1959. Modified after Starzyk (2015b, figure 2.1). Unmarked black circles represent tubercles.

not always present (Paranecrocarcinidae, Zanthopsidae, some Raninoida). Gastric pits can usually be seen on both the internal mold and on the cuticle. For the position of muscle scars and pits, reference is made to Klompmaker et al. (2019, figures 13-14) and Figure 1.

For the most part, the classification system for Mesozoic Brachyura in Schweitzer et al. (2010) was used. However, during the peer review of process of this paper, a new classification was proposed by Guinot (2019). It is outside the scope of this paper to evaluate both hypotheses and we choose not to support or reject one hypothesis at this stage. We have evaluated some of the taxa in detail as suggested by Guinot (2019), but much more research on other taxa is needed.

Institutional abbreviations for specimens referred to herein: I-F/MP=Museum of the Institute of Systematics and Evolution of Animals, Polish Academy of Sciences, Cracow, Poland; LPBIII art=Laboratory of Paleontology, Department of Geology and Paleontology, University of Bucharest, Bucharest, Romania; MAB k=Oertijdmuseum, Boxtel, The Netherlands; MGSB=Museo Geológico del Seminario de Barcelona, Barcelona, Spain; MGUP=Museo Geologico G.G. Gemmellaro, Palermo, Italy; MNHN=Muséum national d'Histoire naturelle, Paris, France; NHMW=Naturhistorisches Museum Wien, Vienna, Austria; SMNS=Staatliches Museum für Naturkunde, Stuttgart, Germany; SNSB-BSPG=Staatliche Naturwissenschaftliche Sammlungen Bayerns-Bayerische Staatssammlung für Paläontologie und Geologie, Munich, Germany; UF=Florida Museum of Natural History (Invertebrate Paleontology), University of 
Florida, Gainesville, Florida, USA.

\section{SYSTEMATIC PALEONTOLOGY}

Order DECAPODA Latreille, 1802 Infraorder BRACHYURA Linnaeus, 1758

Section DROMIACEA De Haan, 1833

Superfamily HOMOLODROMIOIDEA Alcock, 1900

Family GONIODROMITIDAE Beurlen, 1932

Genus EODROMITES Patrulius, 1959

Type species. Prosopon grande von Meyer, 1857, by original designation and monotypy (=Eodromites guenteri Starzyk, 2015b).

Included species. Eodromites bernchrisdomiorum sp. nov., E. cristinarobinsae sp. nov.; E. depressus (von Meyer, 1857) as Prosopon; E. dobrogea (Feldmann, Lazăr, Schweitzer, 2006), as Cycloprosopon; E. grandis (von Meyer, 1857), as Prosopon; E. nitidus (A. Milne Edwards, 1865), as Ogydromites; E. polyphemi (Gemmellaro, 1869), as Prosopon; E. rostratus (von Meyer, 1840), as Prosopon; E. rotundus Starzyk, 2015b.

Remarks. Eodromites guenteri resembles E. grandis in outline and groove pattern. Moreover, the neotype of $E$. grandis originates from the same upper Kimmeridgian strata and from the same region in Germany. Pits on the epibranchial region and just posterior to the upper orbital margin on the internal mold are key features present in the sole specimen of $E$. guenteri to distinguish it from $E$. grandis, which would not have these pits (Starzyk, 2015b). These pits are, however, not consistently present on species represented by many specimens. For example, the posteriormost pits have been observed in only part of the large specimens of $E$. cristinarobinsae sp. nov. (MAB k2950, MAB k3589) and only on one side of the latter specimen. Only one medium-sized specimen of E. cristinarobinsae sp. nov. exhibits all three pits (MAB k2626) and one medium-sized specimen may have both epibranchial pits (MAB k2637), but is otherwise identical to conspecifics. Based on a limited number of relatively small specimens ascribed to $E$. bernchrisdomiorum sp. nov. from the Oxfordian of Poland (I-F/MP/3604/1533/08, I-F/MP/6259/1588/ 11, I-F/MP/3233/1532/08, I-F/MP/6258/1588/11, IF/MP/1701/1517/08, I-F/MP/2932/1532/08), a pit posterior to the right upper orbital margin can be found in some specimens (I-F/MP/3233/1532/08, IF/MP/6258/1588/11, I-F/MP/2932/1532/08), but not for another specimen with relatively wellexposed orbital margins (I-F/MP/6259/1588/11); pits were not seen on the epibranchial regions of these specimens. Unfortunately, no sufficiently well-preserved specimens of Late Jurassic E. gran- dis from Germany were available to assess the degree of variation of pits. To conclude, the variable presence of pits within species of Eodromites demonstrates that the presence/absence of pits is problematic to use to distinguish species. The ratio of length from the outer orbital angle to the cervical groove at the lateral margin divided by the length from the tip of the rostrum to the cervical groove axially would be another difference between $E$. grandis and E. guenteri (Starzyk, 2015b). The one specimen of $E$. guenteri known has a ratio $(0.37)$ comparable to the neotype of $E$. grandis from the same region and age [0.36, using Wehner (1988, plate 7.1), also shown in Schweitzer and Feldmann (2008a, plate 4F)] or even higher for the new German specimen of $E$. grandis $(0.43$, Figure $2 A)$. Furthermore, the neotype of $E$. grandis is comparable in size to $E$. guenteri (10.4 vs $10.6 \mathrm{~mm}$ max. width, resp.) and would plot very close to $E$. guenteri in figure 3 in Starzyk (2015b). According to Starzyk (2015b), E. guenteri has a rostrum that is incised in the middle in contrast to congenerics. However, multiple species of Eodromites exhibit this incision, including E. dobrogea (Schweitzer and Feldmann, $2010 b)$, specimens of $E$. grandis including the neotype (Wehner, 1988, plate 7.1; Schweitzer and Feldmann, 2010a; Figure 2A), and E. cristinarobinsae sp. nov. (Klompmaker et al., 2012; Figures 3, 4). Eodromites guenteri is also said to have the longest augenrest of all studied species (Starzyk, $2015 \mathrm{~b}$ ), but the orbital structure is also long in the new German specimen of $E$. grandis (Figure 2F). As the proposed differences are less prominent to non-existing, we argue that $E$. guenteri is a junior synonym of $E$. grandis.

After Starzyk (2015b) described Eodromites hyznyi and E. rotundus, both species were transferred to Tanidromites by Schweitzer et al. (2017) based on narrow, triangular fronts similar to Tanidromites, the straighter lateral margins more comparable to Tanidromites, the relatively shallow augenrest, and the lower orbital rim not extending beyond the upper orbital margin as in Tanidromites. Although the rostrum of E. rotundus appears less downturned and the carapace surface seems more uneven than most species of Eodromites (Starzyk, 2015b, figure 6), a straighter lateral margin does not apply to $E$. rotundus (narrowing posteriorly instead), the lower orbital rim can extend beyond the upper orbital margin for Eodromites (type species E. grandis, Figure 2A), and augenrests with comparable depth to $E$. rotundus are also found in $E$. bernchrisdomiorum sp. nov. Moreover, the base of the rostrum of $E$. rotundus is 


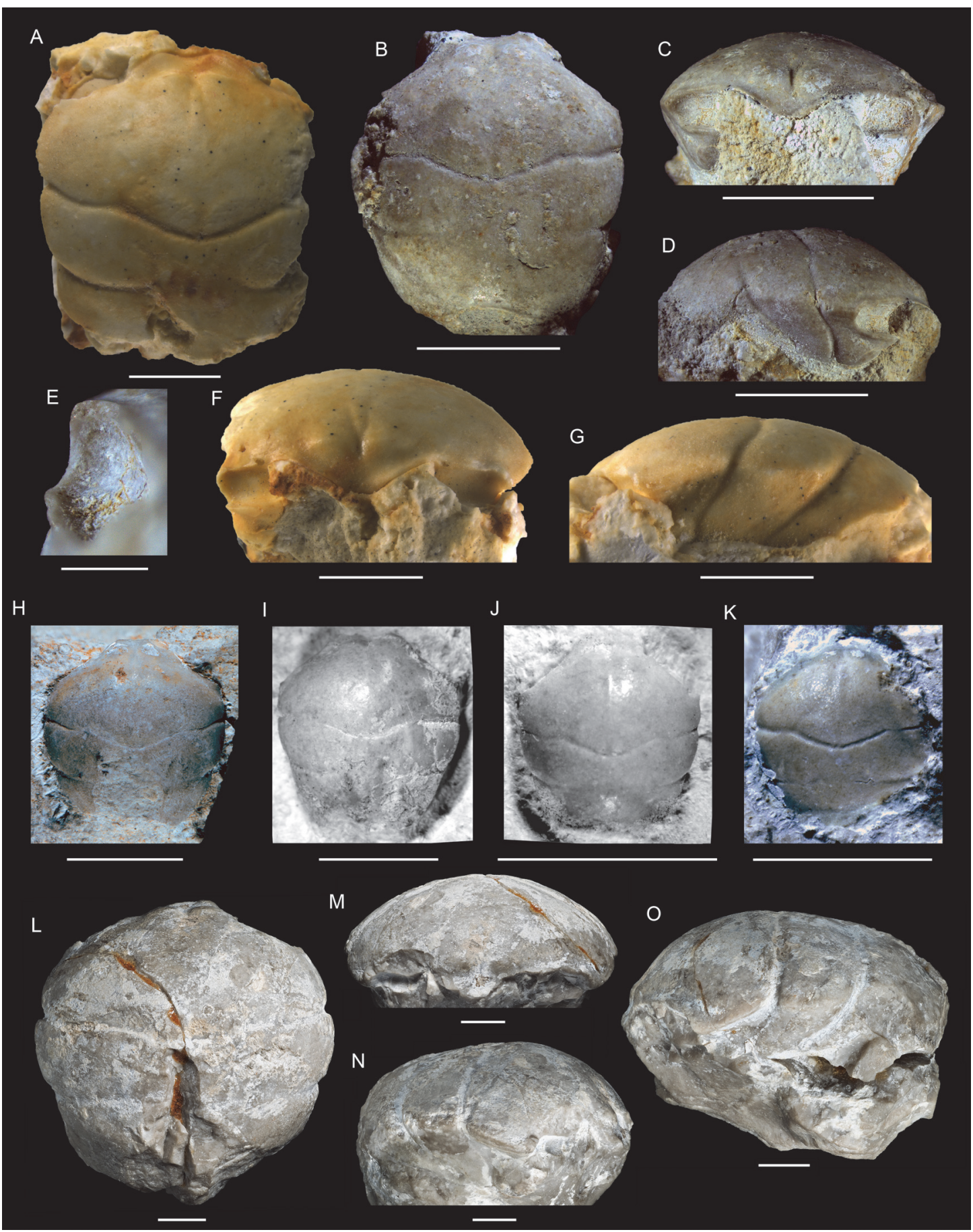

FIGURE 2. Specimens of the crab Eodromites spp. from the Late Jurassic of Europe. A, F, G, Eodromites grandis (von Meyer, 1857) from the Upper Jurassic (upper Kimmeridgian) coral limestones of Saal an der Donau in southern Germany in dorsal, frontal, and left-lateral views, resp. (SNSB-BSPG 2016 XXI 404). B-E, Holotype of Eodromites bernchrisdomiorum sp. nov. from the Upper Jurassic (lower-middle Oxfordian) deposits of Ogrodzieniec in southern Poland in dorsal, frontal, right-lateral, and orbital views, resp. (I-F/MP/6259/1588/11). E, an oblique view of right orbital structure, primarily the lateral margin with a wide fissure. H-K, Late Jurassic (Oxfordian) Eodromites bernchrisdomiorum sp. nov. from southern Poland in dorsal view (H, I-F/MP/4874/1534/08, Niegowonice, middle-late Oxfordian; I, I-F/ MP/6255/1588/11, paratype, Niegowonice, middle-late Oxfordian; J, I-F/MP/6258/1588/11, Ogrodzieniec, early-middle Oxfordian, paratype; K, I-F/MP/1369/1508/08, Bzów, middle Oxfordian). L-O, Holotype of Eodromites polyphemi (Gemmellaro, 1869) from the Late Jurassic (Tithonian) of Sicily, Italy, in dorsal, frontal, right-lateral, and left-lateral views, resp. (MGUP-020.18). Scale bar width is $5.0 \mathrm{~mm}$, except for $\mathbf{E}(1.0 \mathrm{~mm})$. 
fairly wide as in Eodromites. Thus, placement of $E$. rotundus in Tanidromites does not appear to be strongly supported, so we transfer this species into its original genus, Eodromites. We agree with Schweitzer et al. (2017) that Eodromites hyznyi fits better in Tanidromites.

Another taxon to reconsider here is Eodromites aequilatus, which Schweigert and Koppka (2011) placed in Eodromites, followed by subsequent authors (Starzyk, 2015b; Hyžný et al., 2015; Schweitzer et al., 2017, 2018), although no detailed explanation was provided. In fact, $E$. aequilatus was compared to multiple morphologically similar species of Tanidromites, and it was concluded that the similarities between Eodromites and Tanidromites suggest that they are phylogenetically close (Schweigert and Koppka, 2011). Subsequently, Starzyk (2015b, p. 17) mentioned that $E$. aequilatus is close to Tanidromites in carapace shape and details of the augenrest, although "the augenrest in Tanidromites is flat, whilst in Eodromites it is deep (concave)." However, T. alexandrae and T. schweitzerae do bear deeper augenrests. Furthermore, E. aequilatus fits the diagnosis of Tanidromites (Starzyk, 2016), including the tall flanks and the similarity in overall rectangular shape, unlike species of Eodromites that tend to narrow much more posteriorly. An inflated subhepatic region as in $E$. aequilatus can also be seen in Tanidromites insignis (Schweigert and Koppka, 2011, figure 6C) and Tanidromites scheffnerae (I-F/MP/6261/1588/11, I-F/MP/6263/1588/ 11 ), and a circle of hepatic pits (=antennar extensor muscle scars), initially suggested to be characteristic of Eodromites including E. aequilatus (Starzyk, 2015b), is also present in Tanidromites scheffnerae from Poland and Austria (pers. obs. AAK) and T. nightwishorum sp. nov. from Austria (see below). Pithonoton, in which E. aequilatus was placed prior to Schweigert and Koppka (2011) placing this species in Eodromites, is mentioned to have short lateral sides and no subhepatic swelling for the specimens examined (Schweitzer and Feldmann, 2008a), unlike E. aequilatus. In conclusion, we transfer $E$. aequilatus to Tanidromites.

\section{Eodromites bernchrisdomiorum sp. nov. Figure 2B-E, H-K}

\section{zoobank.org/67AB3730-8635-40B1-A40A-9306798B7DA5}

2015b Eodromites grandis (von Meyer, 1857); Starzyk, p. 6 , fig. 4.

Diagnosis. Carapace slightly longer than wide (I/w ratio $\sim 1.1$ ), with fairly small maximum size up to $\sim 10 \mathrm{~mm}$ long, ovate in shape, widest at hepatic or epibranchial region. Fronto-orbital margin only slightly smaller than maximum width. Ratio of length from outer orbital angle to cervical groove at lateral margin divided by length from tip of rostrum to cervical groove axially $0.28-0.34$. Rostrum with broad base, triangular, downturned, with blunt tip, with axial concavity in dorsal view. Orbits moderately deep, wider than tall, anterolaterally oriented. Upper orbital margin without protrusion at outer orbital angle; shallow fissure in orbital margin at lateralmost part of lower orbital margin.

Etymology. Named after the brothers of AAK: Bernie, Christiaan, and Dominick Klompmaker.

Material studied. Holotype: I-F/MP/6259/1588/11; paratypes: I-F/MP/6255/1588/11, I-F/MP/6258/ 1588/11; other material: I-F/MP/1369/1508/08, I-F/ MP/3526/1533/08, I-F/MP/3604/1533/08, I-F/MP/ 4874/1534/08, I-F/MP/4927/1534/09, I-F/MP/6257I 1588/11, UF 272090, UF 272100.

Description. Carapace slightly longer than wide (I/ w ratio $\sim 1.1$ ), with fairly small maximum size up to $\sim 10 \mathrm{~mm}$ long, ovate in shape, strongly vaulted in both directions, widest at hepatic or epibranchial region. Fronto-orbital margin only slightly smaller than maximum width. Ratio of length from outer orbital angle to cervical groove at lateral margin divided by length from tip of rostrum to cervical groove axially $0.28-0.34$. Lateral margins distinctly rimmed anteriorly, less so at epibranchial regions, not rimmed at meso-metabranchial regions. Posterior margin slightly concave. Rostrum with broad base, triangular, downturned, with blunt tip, with axial concavity in dorsal view. Orbits moderately deep, wider than tall, anterolaterally oriented. Upper orbital margin without protrusion at outer orbital angle; shallow fissure in orbital margin at lateralmost part of lower orbital margin; lower orbital margin appears rectangular, not extending beyond upper orbital margin. Epigastric regions swollen, adjacent to tip mesogastric region. Protogastric and hepatic regions confluent. Subhepatic region bulbous. Mesogastric region triangular to pyriform, with pair of scabrous posterior gastric muscle scars at base (Figure 2B) and weak axial groove in between, best defined anteriorly and posteriorly, weakly so in middle part. Uro-metagastric region indistinct, wide, confluent with epibranchial regions. Large epibranchial regions somewhat swollen laterally. Cardiac region, weakly delimited, subtriangular to pentagonal, usually with three tubercles in triangle pointing posteriorly. Mesometabranchial regions confluent, depressed laterally. Intestinal region appears depressed. Cervical groove moderately strong, sinuous, with gastric pits on both sides of axis, curving around subhe- 
patic region on lateral side. Postcervical groove weak. Branchiocardiac groove strongest away from longitudinal axis, nearly transverse on dorsal side, bending forward on lateroventral side. Posterior margin with groove. Epibranchial pits not observed, pit on upper orbital margin sensu Starzyk (2015b) not consistently present. Internal mold with some tubercles. Cuticle, appendages, ventral side, and abdomen unknown.

Occurrence. Late Jurassic (Oxfordian) of southern Poland. Bzów (middle Oxfordian, transversarium Zone): I-F/MP/1369/1508/08, I-F/MP/3526/1533/ 08, I-F/MP/3604/1533/08. Niegowonice (middleupper Oxfordian, upper elisabethae-upper Wartae Subzone): I-F/MP/4874/1534/08, I-F/MP/4927/ 1534/09, I-F/MP/6255/1588/11. Ogrodzieniec (lower-middle Oxfordian, cordatum-transversarium Zone, with exception of the discontinuous mariae Zone): I-F/MP/6257/1588/11, I-F/MP/6258/1588/ 11, I-F/MP/6259/1588/11. Szklary (middle Oxfordian): UF 272090, UF 272100.

Dimensions. (In mm) I-F/MP/1369/1508/08: max. length excl. rostrum $(L)=-$, max. width $(W)=4.7 ; \mathrm{I}-\mathrm{F} /$ MP/6259/1588/11: $L=10.2, \quad W=9.3 ; \quad I-F / M P / 3526 /$ 1533/08: $\quad L=8.7, \quad W=8.1 ; \quad I-F / M P / 3604 / 1533 / 08$ : $L=10.3, W=9.8$; I-F/MP/4874/1534/08: L=-, W=7.7; I-F/MP/4927/1534/09: L=-, W=7.2; I-F/MP/6255/ 1588/11: L=-, $W=7.9$; I-F/MP/6257/1588/11: $L=3.8$, $W=3.6$; I-F/MP/6258/1588/11: L=-, W=4.2.

Remarks. Compared to the type species, Eodromites grandis, the proportional distance from the outer orbital angle to the cervical groove is shorter than in E. grandis. This difference applies to all species of Eodromites except E. nitidus and E. rostratus (Appendix 1). The anterolateral margin anterior to the cervical groove is less curved compared to $E$. grandis, resulting in a proportionally wider occupation of the fronto-orbital margin of the maximum width. Moreover, the maximum size (length=10 $\mathrm{mm}$ ) and width $(9 \mathrm{~mm}$ ) based on 23 specimens (Starzyk, 2015b) is substantially smaller than that of E. grandis (e.g., Appendix 1). Eodromites bernchrisdomiorum sp. nov. has a proportionally shorter anterolateral margin anterior to the cervical groove, and the orbits are more anterolaterally oriented than in E. cristinarobinsae sp. nov. Furthermore, the fissure in the lower orbital margin near the lateralmost part of the margin in E. cristinarobinsae sp. nov. (MAB k2950, 2626, 3589; UF 271883 ) is narrower and more prominent than in $E$. bernchrisdomiorum (UF 272100, UF 272090, I-F/ MP/6259/1588/11, I-F/MP/6258/1588/11). We provide some additional differences per species here. Eodromites depressus has a proportionally nar- rower branchial region than the new species; $E$. dobrogea and E. polyphemi are more circular in outline in dorsal view; the drawing of $E$. nitidus exhibits more protruding lower orbital margins; the drawing of $E$. rostratus appears to have a less protruding rostral area; and E. rotundus shows a rostrum that is pointing more forwardly. The limited number of well-preserved specimens available does not allow for a detailed analysis of possible ontogenetic changes and intraspecific variation.

\section{Eodromites cristinarobinsae sp. nov. \\ Figures 3, 4}

zoobank.org/0C2666F1-87E8-45CF-A13F-454831236171

2012 Eodromites grandis (von Meyer); Klompmaker et al., p. 790 , fig. 5 .

Diagnosis. Carapace ovoid to rectangular, narrowing posteriorly. Lateral margins distinctly rimmed anteriorly, rounded posteriorly. Rostrum triangular with axial concavity. Orbits deep and wide. Deep fissure in the lower orbital margin. Sinuous cervical groove in large specimens (see Klompmaker et al., 2012, figure 5).

Etymology. Named after Cristina M. Robins, expert on fossil galatheoid decapods.

Material studied. Holotype: MGSB78750 [previously MAB k2951 as in Klompmaker et al. (2012)]; paratypes: MAB k2952 (Klompmaker et al., 2012, figure 5C), 3592; UF 271883; other material: MAB k2475, 2513, 2626, 2638, 2950, 2953, 2954, 3089,

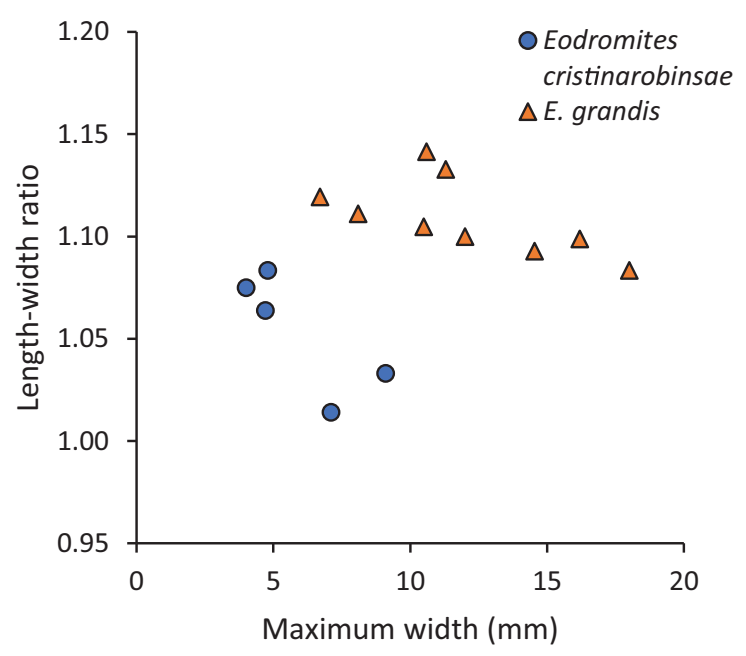

FIGURE 3. Length-width ratios versus maximum width of carapaces of Eodromites grandis compared to $E$. cristinarobinsae sp. nov. (previously identified as $E$. grandis). Data: Appendix 2. 


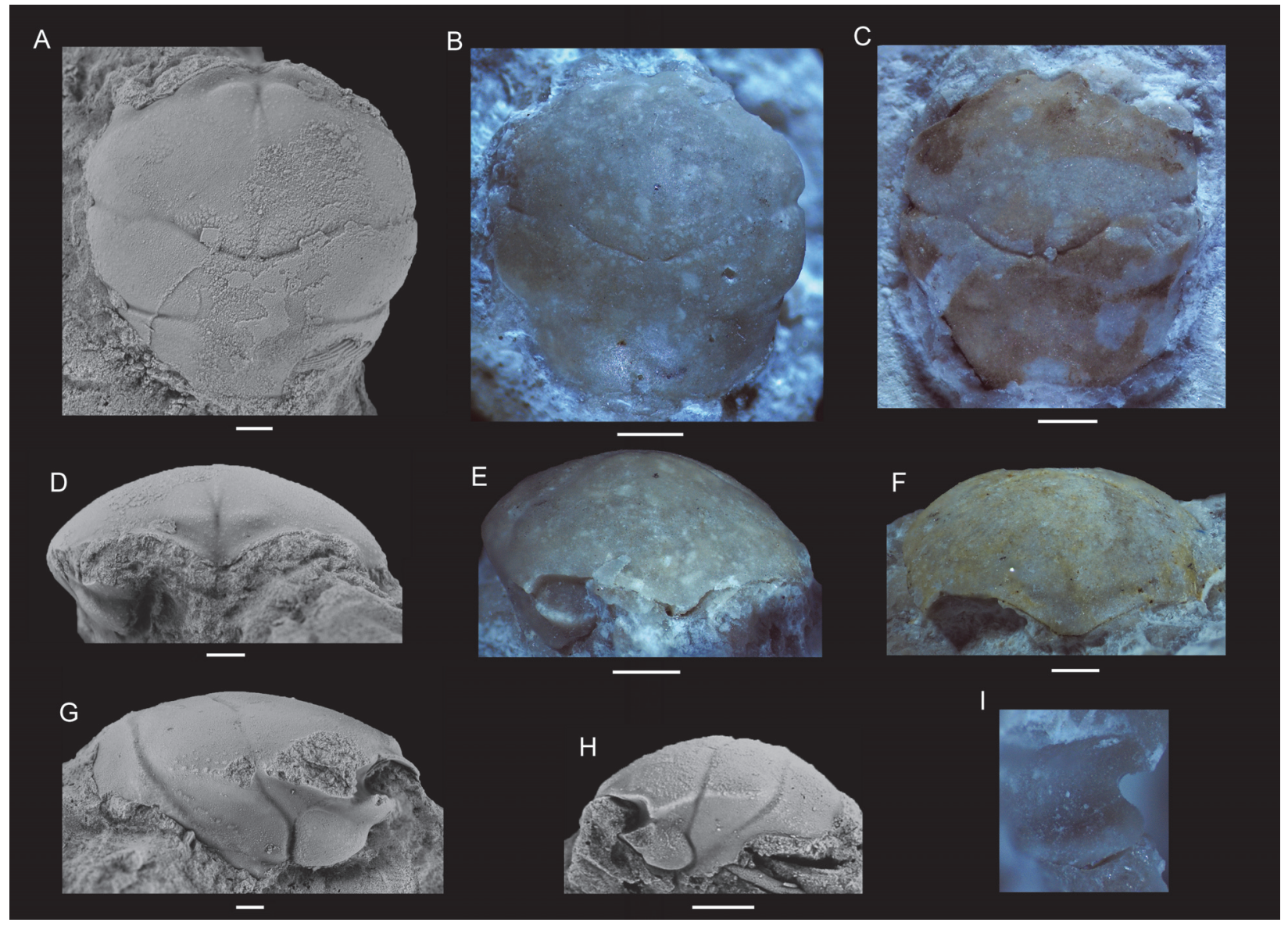

FIGURE 4. Specimens of the crab Eodromites cristinarobinsae sp. nov. from the mid-Cretaceous (lower upper Albian) reef limestones of Koskobilo, northern Spain. A-C, dorsal views (holotype MGSB78750, paratype UF 271883, and paratype MAB k3592, resp.). D-F, frontal views (MGSB78750, UF 271883, and MAB k2638, resp.). G, H, right- and left-lateral views (MAB k2950 and MAB k2953, resp.). I, oblique view of lateral part of orbital structure with fissure (MAB k2626); upper orbital margin incomplete; height figure $\sim 1.0 \mathrm{~mm}$. A, D, G, and $\mathbf{H}$ colored dark and subsequently coated with ammonium chloride prior to photography; from Klompmaker et al. (2012, figure 5B, H, J, and K, reproduced with permission). Those images are not published under the terms of the CC-BY license of this article. For permission to reuse, please see Klompmaker et al. (2012). Scale bar width equals $1.0 \mathrm{~mm}$.

3589, 3596; UF 271792, UF 271793, UF 271794 , UF 271835.

Occurrence. Koskobilo quarry, northern Spain (coordinates in Google Earth: 42.88, -2.20), reef limestones of the lower upper Albian Albeniz Unit of the Eguino Formation (Klompmaker, 2013a; López-Horgue and Bodego, 2017).

Dimensions. (In mm) MAB k3592: max. length excl. rostrum but incl. epigastric swellings $(L)=5.2$, max. width $(\mathrm{W})=5.0$; UF 271883: $L=4.8, W=4.7$; see Klompmaker et al. (2012, table 2) for more measurements.

Description. Carapace longer than wide in small specimens, about as long as wide in large specimens; oval to rectangular in shape; strongly vaulted in both directions in small specimens, moderately so for large specimens; widest at hepatic or epibranchial region. Fronto-orbital margin slightly smaller than maximum width. Lateral margins distinctly rimmed anteriorly, less so at epibranchial regions, not at meso-metabranchial regions. Posterior margin straight to slightly concave. Rostrum with wide base, triangular, downturned, with blunt tip, with axial concavity in dorsal view. Orbits deep, wider than tall, somewhat anterolaterally oriented, with vertical rim within orbit. Upper orbital margin with protrusion at outer orbital angle in larger specimens; deep fissure in orbital margin at lateralmost part of lower orbital margin; lower orbital margin rectangular, straight to weakly concave in dorsal view, not extending beyond upper orbital margin. Epigastric regions weak, transversely oriented. Protogastric and hepatic regions confluent, may show circular region with pits representing anten- 
nar extensor muscle scars (Figure 4A). Subhepatic region bulbous. Mesogastric region triangular to pyriform, with pair of scabrous posterior gastric muscle scars at base and weak axial groove in between, best defined anteriorly and posteriorly, weakly so in middle part. Uro-metagastric region indistinct, wide, confluent with epibranchial regions. Large epibranchial regions somewhat swollen laterally. Cardiac region pentagonal, weakly delimited, usually with three tubercles in triangle pointing posteriorly. Meso-metabranchial regions confluent, depressed laterally. Intestinal region not visible. Cervical groove moderately strong, with gastric pits on both sides of axis, strongest axially, widely V-shaped axially, then sinuous or at lower angle to longitudinal axis, with short transverse middle segment in large specimens, curving around subhepatic region on lateral side. Postcervical groove weak, absent axially. Branchiocardiac groove strongest away from longitudinal axis, nearly transverse on dorsal side, bending forward on lateroventral side to join cervical groove below subhepatic region. Posterior margin with groove. Epibranchial pits and pit on upper orbital margin sensu Starzyk (2015b) variably present. Weak tubercles laterally and anteriorly in some large specimens. Cuticle, appendages, majority of ventral side, and abdomen unknown.

Remarks. Specimens of this taxon were studied previously and referred to Eodromites grandis (Klompmaker et al., 2012). The differences they noted were ascribed to intraspecific variation, including a larger maximum size for Late Jurassic specimens, possibly a somewhat more concave posterior margin, and a deeper fissure in the lower orbital margin. As a result of the collection of new specimens from Koskobilo (e.g., MAB k3592, $3589,3596)$ and a non-cast specimen of $E$. grandis from the late Kimmeridgian of Germany (SNSBBSPG 2016 XXI 404) for comparison, our restudy has led to the erection of the new species.

The new species is different from Eodromites grandis (Figure 2) in multiple aspects. The fissure in the lower orbital margin near the lateralmost part of the margin in E. cristinarobinsae sp. nov. (MAB k2950, 2626, 3589; UF 271883) is indeed narrower and more prominent than in the Kimmeridgian specimen from Germany (SNSB-BSPG 2016 XXI $404)$ and using existing images in the literature (Wehner, 1988, plate 7.2B; Schweitzer and Feldmann, 2008a, plate 4C, D; Schweitzer and Feldmann, 2010a, figure 5.1; Hyžný et al., 2015, figure $6 \mathrm{~A})$. The more concave posterior margin for the Late Jurassic specimens of $E$. grandis is also con- firmed. Maximum size is difficult to use as a convincing difference because size may be (micro)habitat-dependent (e.g., Klompmaker et al., $2013 a, 2015 a)$. Finally, the length-width ratios of $E$. cristinarobinsae sp. nov. are smaller than those of E. grandis for similar-sized specimens (Figure 3). Moreover, using all data yields a statistical difference in length-width ratios (Mann-Whitney $\mathrm{p}=0.004)$.

Other species of Eodromites differ as well from the new species. Differences between $E$. bernchrisdomiorum sp. nov. and E. cristinarobinsae sp. nov. have been described above. Eodromites depressus has much more depressed metamesobranchial regions compared to E. cristinarobinsae sp. nov. (von Meyer, 1860, plate 23.18). Eodromites dobrogea is close to the new species, but its upper orbital margin lacks a projection at the outer orbital angle (Feldmann et al., 2006, figure 3.10; Schweitzer et al., 2007a, figure 4.3; Schweitzer and Feldmann, 2010a, figure 5.4-6) as seen in E. cristinarobinsae sp. nov. Moreover, the upper orbital margin of $E$. dobrogea bears granules or tiny spines (Schweitzer and Feldmann, 2010b), absent in E. cristinarobinsae sp. nov. The pits on the carapace cannot be used to distinguish the two species as they are variably present on the new species (see also above). Assuming that the drawing of $E$. nitidus is accurate (A. Milne-Edwards, 1865 , plate $5.1 \mathrm{a}$ ), E. nitidus has a lower orbital margin that is protruding much more in dorsal view and the axial part of the rostrum does not show a concavity in dorsal view as in E. cristinarobinsae sp. nov. The course of the cervical groove of $E$. polyphemi is more continuous and does not contain a short transverse middle segment as in large specimens of E. cristinarobinsae sp. nov. The single specimen of $E$. polyphemi is larger than any reported specimen of $E$. cristinarobinsae sp. nov. known thus far (Klompmaker et al., 2012; Appendix 2). Again, if the drawing of $E$. rostratus (von Meyer, 1860 , plate 23.3) is accurate, the cervical groove of E. rostratus is more transversely oriented away from the longitudinal axis in E. rostratus. Finally, Eodromites rotundus has a less downturned rostrum and an orbital margin that appears more open laterally.

Ontogenetic differences were noted previously with smaller specimens being proportionally longer and more vaulted (Klompmaker et al., 2012). Furthermore, the cervical groove is more sinuous in larger specimens. Although the orbital structure has been used previously to distinguish between Eodromites species (Starzyk, 2015b), 
possible ontogenetic changes were not investigated thus far. The extent of the fissure in the lower orbital margin does not change much if anything as the animal grows, implying that this aspect of the orbital structure can be used to distinguish between species in Eodromites. The protrusion at the outer orbital angle is more pronounced in larger specimens (Klompmaker et al., 2012, figure 5; Figure 4).

Eodromites polyphemi (Gemmellaro, 1869) Figure 2L-O

1869 Prosopon polyphemi Gemmellaro, p. 169, pl. 7.59 .

Diagnosis. Carapace widest at epibranchial regions; moderately convex longitudinally and transversely; anterolateral margin curving inward; lateral margins rimmed from orbital angle to intersection with branchiocardiac groove, strongest anteriorly; cervical and branchiocardiac groove prominent; cervical groove weakly sinuous.

Material studied. Holotype: MGUP-020.18.

Description. Carapace large for genus, subcircular in dorsal view as preserved, widest at epibranchial regions, moderately convex longitudinally and transversely. Fronto-orbital width $\sim 80 \%$ of maximum width. Orbital structure incompletely preserved, containing vertical ridge with augenrest lateral to it. Rostrum downturned, incomplete. Epigastric regions subcircular and swollen, marking base of rostrum. Protogastric, hepatic, and mesogastric regions not differentiated. Base of mesogastric region with posterior gastric muscle scars. Cardiac and meta-urogastric regions not preserved. Epibranchial regions rectangular as preserved. Meso-metabranchial regions confluent, incomplete. Cervical groove prominent, widely Vshaped, somewhat sinuous; where preserved, prominent branchiocardiac groove parallels cervical groove; both grooves curve forward on flank. Obliquely oriented, lateralmost parts of post-cervical groove present. Lateral margins mostly rimmed, very strongly so anterolaterally, less so at epibranchial regions, and not rimmed at mesometabranchial regions. Posterior margin not preserved. Flanks inclined inward as preserved. Ornamentation poorly preserved; cuticle appears pitted where present (new description based on photographs only; see also Gemmellaro (1869: p. 169170)).

Occurrence. Late Jurassic (Tithonian) of northern Sicily, Italy (precise coordinates unknown).

Dimensions. (In mm) MGUP-020.18: max. length excl. rostrum=-, max. width $=33$.
Remarks. This species has been only known from a drawing since the erection of the species (Gemmellaro, 1869, plate 7.59). Some authors have suspected that this species represents a junior synonym of Eodromites grandis while maintaining them as separate species (Van Straelen, 1925; Schweitzer and Feldmann, 2008a; Klompmaker et al., 2012), whereas Wehner (1988) synonymized the two taxa. The holotype of Eodromites polyphemi has never been studied since Gemmellaro, and several researchers called for a study of the holotype (Schweitzer and Feldmann, 2008a; Klompmaker et al., 2012). Without having seen the specimen ourselves, we here provide the first photographs of the holotype. The holotype of E. polyphemi represents a large specimen $(33 \mathrm{~mm}$ in maximum width), but the posterior part is mostly lacking. In this case, the drawing in Gemmellaro represents the actual specimen fairly well. Possible differences between the two taxa were discussed previously (Gemmellaro, 1869; Schweitzer and Feldmann, 2008a; Klompmaker et al., 2012). However, the best possible comparison between $E$. grandis and E. polyphemi can only be made using similar-sized specimens so that any differences due to allometric growth can be ruled out. Although an equally-sized specimen of $E$. grandis has been reported (33 $\mathrm{mm}$ in width, see Moericke, 1889, p. $67)$, this specimen has never been figured. The largest figured specimens of $E$. grandis known to us are $\sim 22 \mathrm{~mm}$ wide (see Schweitzer and Feldmann, 2008a, plate 4E; Schweitzer and Feldmann, $2010 \mathrm{~b}$, figure 5.3). Any other specimens of $E$. polyphemi are unknown. We also note that E. polyphemi possesses an anterior dorsal region reminiscent of $E$. dobrogea, but the lack of the posterior part of $E$. polyphemi precludes a full comparison as well as the lack of similarly large specimens of $E$. dobrogea. Therefore, we cannot fully evaluate differences between $E$. polyphemi and E. grandis/ $E$. dobrogea, so we questionably maintain E. polyphemi as a separate species for now.

\section{Genus NAVARRADROMITES Klompmaker,} Feldmann, and Schweitzer, 2012

Type and sole species. Navarradromites pedroartali Klompmaker, Feldmann, and Schweitzer, 2012, by monotypy.

Navarradromites pedroartali Klompmaker, Feldmann, and Schweitzer, 2012

\section{Figure 5}

2012 Navarradromites pedroartali Klompmaker, Feldmann, and Schweitzer, p. 798, fig. 8. 


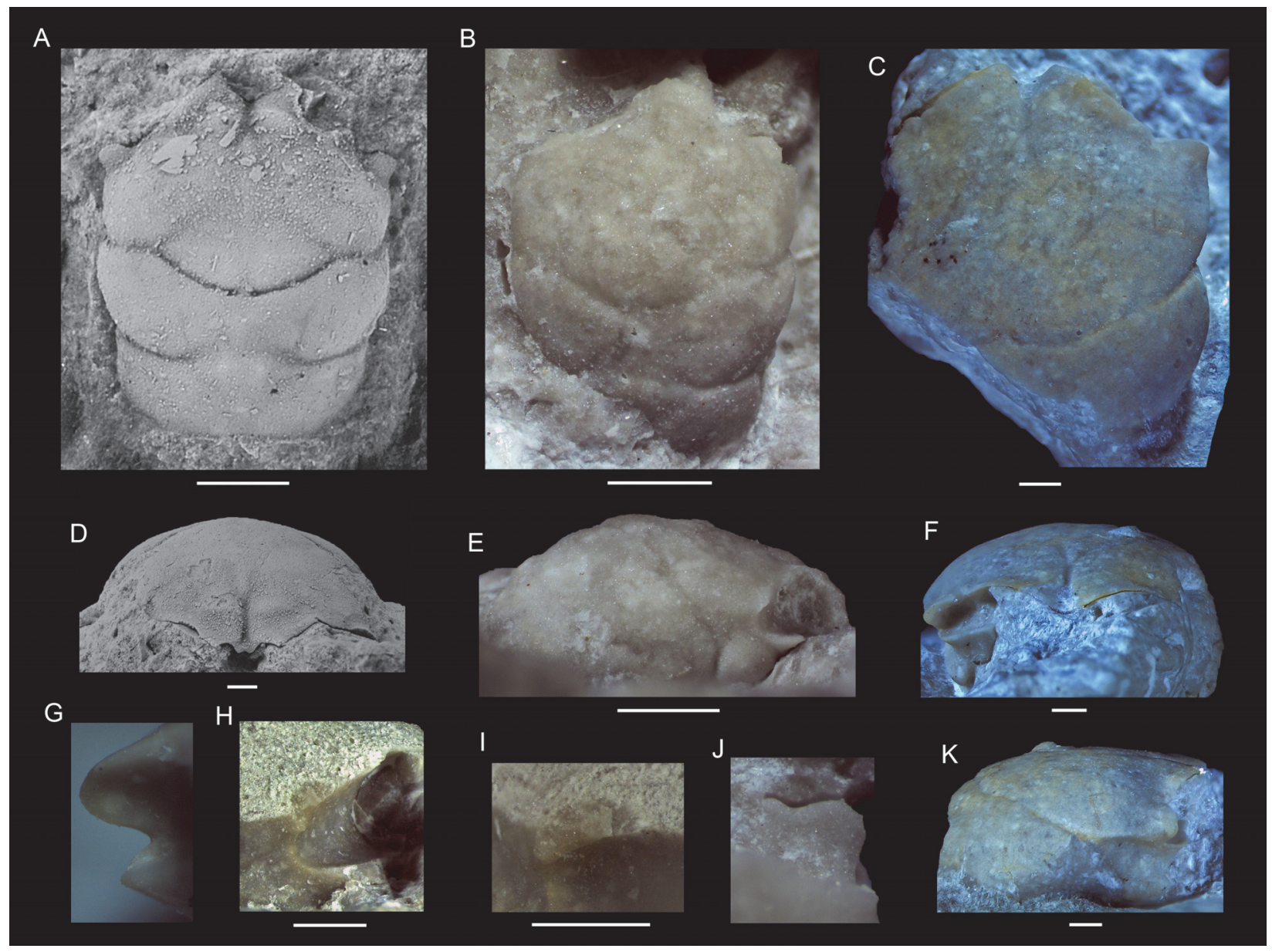

FIGURE 5. Specimens of the crab Navarradromites pedroartali Klompmaker et al., 2012, from the mid-Cretaceous (early late Albian) of Koskobilo, northern Spain. A-C, dorsal views (holotype MGSB77711, MAB k3593, and MAB k3591, resp.). D, F, frontal views showing somewhat different rostral tips (MAB k3018 and MAB k3591, resp.). E, K, right-lateral views (MAB k3593 and MAB k3591, resp.). G, H, views of orbital structure with fissure laterally (MAB k3591 and paratype MAB k3182, resp.); height $\mathrm{G} \sim 1.0 \mathrm{~mm}$. I, frontal view of damaged upper orbital projection that is wider than tall (paratype MAB k3182). J, lower orbital margin (upper orbital margin is not complete), width figure $\sim 0.5$ $\mathrm{mm}$ (MAB k3593). A and D colored dark and subsequently coated with ammonium chloride prior to photography; from Klompmaker et al. (2012, figure 8D, I, reproduced with permission). Those images are not published under the terms of the CC-BY license of this article. For permission to reuse, please see Klompmaker et al. (2012). Scale bar width equals $1.0 \mathrm{~mm}$.

2012b Navarradromites pedroartali Klompmaker,

Feldmann, and Schweitzer; Schweitzer et al., p. 6, fig. 5.3.

Diagnosis. Klompmaker et al. (2012, p. 796).

Material studied. Paratypes: MAB k2956, 2516, 2955, 3018, 3182; other material: 2957, 3593, 3594, 3595, UF 271729.

Occurrence. Koskobilo quarry, northern Spain (coordinates in Google Earth: 42.88, -2.20), reef limestones of the lower upper Albian Albeniz Unit of the Eguino Formation (Klompmaker, 2013a; López-Horgue and Bodego, 2017).

Dimensions. (In mm) MAB k3591: max. length excl. rostrum but incl. epigastric swellings $(\mathrm{L})=-$, max. width $(W)=9.9$; $M A B$ k3593: $L=-, W=2.7$; see Klompmaker et al. (2012, table 2) for more measurements.

Description. Referral is made to Klompmaker et al. (2012, p. 799). New details of orbital structure: lateral side of orbits usually show a wide fissure or re-entrant (MAB k2516, 2955, 2956, 3182, 3591, 3593, and 3595); anterolaterally oriented outer orbital spine wider than tall in cross-section (MAB k3182, 3593); lower orbital margin does not project beyond upper orbital margin (MAB k3593, 3591); and rectangular lower orbital margin exhibits a weak concavity in dorsal view (MAB k3593, 3591). Rostrum in frontal view with small, downturned, 
axially indented projection for some large specimens (MAB k3018, 3182, 3594) or with single small triangle in small specimens (MAB k29552957).

Remarks. As Eodromites cristinarobinsae sp. nov. and Navarradromites pedroartali can look very similar to one another for incompletely preserved specimens, differences are highlighted here. The outer orbital spines break off easily and so do the rostral spines, which make them appear almost identical to specimens of $E$. cristinarobinsae sp. nov. When well-preserved, these orbital spines tend to be more pronounced in N. pedroartali. The downturned, indented projection of the rostrum in frontal view for large specimens of $N$. pedroartali appears absent in E. cristinarobinsae sp. nov. for similar-sized specimens, where this character is either pointed or straight [MAB k2513, 2626, 2638 (Figure 4F)]. Lastly, the lateralmost part of the cervical groove in dorsal view tends to bend forward more so than in Eodromites cristinarobinsae sp. nov. (see Klompmaker et al., 2012; Figures 4, 5).

A previous article (Klompmaker et al., 2012, p. 796) found placement in homolodromiids unlikely because "the carapace of the homolodromiids has its widest part typically in the posterior [or central] part of the carapace, [the former of] which is the part that is typically narrowest in Navarradromites." Comparisons to homolodromiids deserve a more extensive discussion because of multiple striking similarities. The frontal structure with two rostral spines in dorsal view and the anterolaterally projected outer orbital spines are very reminiscent of extant (e.g., Guinot, 1995; Martin et al., 2001; Ng and McLay, 2005; Lemaitre and Tavares, 2014) and fossil (Förster et al., 1985; Feldmann, 1993; Schweitzer and Feldmann, 2010d, for Homolus auduini Eudes-Deslongchamps, 1835) homolodromiids. Additionally, the concavity or opening in the orbital rim in lateral view in Navarradromites (but see MAB k3591) is also seen in extant homolodromiids (e.g., Báez and Martin, 1989; Martin et al., 2001; Ng and McLay, 2005; Lemaitre and Tavares, 2014). However, a spine on the lower orbital margin that is often present in homolodromiids (Martin, 1990; Guinot, 1995; Schweitzer et al., 2004; Schweitzer and Feldmann, 2010d; Lemaitre and Tavares, 2014) is absent in Navarradromites. Furthermore, based on a limited number of specimens, the orbits of homolodromiids appear shallower usually (Förster et al., 1985, p. 344; Báez and Martin, 1989, figure 2A; Martin, 1990, figure 2B but see figure 5B; Feldmann et al., 1993, figure 27.2; Lemaitre and Tavares, 2014, figure 5C) than in Navarradromites. Together with these differences in the orbital region, the different overall outline and the close similarity to Eodromites in shape and groove pattern suggest that placement within Goniodromitidae remains best supported. The frontal structure with a bifid rostrum and anterolaterally oriented spines is a remarkable example of convergent evolution of Navarradromites toward members of Homolodromiidae, for which this type of frontal structure is characteristic.

Family HOMOLODROMIIDAE Alcock, 1900

Genus NODOPROSOPON Beurlen, 1928b

Type species. Prosopon ornatum von Meyer, 1857 , by original designation and monotypy.

Included species. ?Nodoprosopon echinorum Collins in Collins and Wierzbowski, 1985; N. ornatum (von Meyer, 1857), as Prosopon.

Remarks. Nodoprosopon was originally placed in Prosopinidae (=Prosopidae) by Beurlen (1928b) and Prosopidae was still its placement in 2007 (Schweitzer et al., 2007a). Subsequently, Schweitzer and Feldmann (2009d) placed this genus in a new family, Nodoprosopidae, because they found the shape of the carapace and rostrum to be unique among Jurassic brachyurans and the genus differed from members of Prosopidae and Longodromitidae. They recognized that placement of Nodoprosopidae within Glaessneropsoidea may be an issue because the orbital structure was unknown. Despite attempts to reveal the orbits, we did not find a single orbital cavity in 28 specimens of Nodoprosopon ornatum, from which we conclude that this cavity is likely to have been poorly developed and/or lightly calcified. Guinot (2019) opined that Nodoprosopon may be close to Bucculentidae. There are multiple similarities including the overall regional definition, but differences also exist such as the orbits and the hepatic region of Bucculentum Schweitzer and Feldmann, 2009d, which is much more swollen, so that the carapace of bucculentids is more rectangular in shape than in Nodoprosopon (Guinot, 2019; pers. obs. AAK). The trifid rostrum combined with the outer orbital spines are not known among Glaessneropsoidea, but they are characteristic of Homolodromiidae (Homolodromioidae). This still extant family is represented by Homolus auduini Eudes-Deslongchamps, 1835, in the Jurassic (Schweitzer and Feldmann, 2010d). Nodoprosopon fits Homolodromiidae well in many aspects (Schweitzer et al., 2004, 2012b): overall outline of dorsal carapace with diverging lateral margins posteriorly, presence of outer orbital and rostral spines (one central spine at a lower level and two diverging spines), 
lacking well-defined orbits, a somewhat inflated subhepatic region, well-defined cervical and branchiocardiac grooves paralleling each other, and a spinose character on anterior carapace as in a number of fossil members $(H$. auduini and Antarctidromia inflata Förster, Gaździcki, and Wrona, 1985). Thus, we propose that the trifid rostrum and outer orbital spines in Nodoprosopon are not an example of convergent evolution toward members of Homolodromiidae. Instead, we place Nodoprosopon in Homolodromiidae.

Rostral spines on their own do represent an example of convergent evolution, however. Diverging rostral spines in combination with a posteriorly widening carapace also occur in the mid-Cretaceous majoids, Priscinachidae Breton, 2009 (Breton, 2009; Klompmaker, 2013a). However, Nodoprosopon bears a third, central rostral spine and appears to exhibit less developed orbits not visible adjacent to the rostral structure and without notches. Another Mesozoic crab, the homolid Doerflesia ornata Feldmann and Schweitzer, 2009, characterized by a linea homolica not observed in Nodoprosopon, also bears two diverging rostral spines. Other non-homolodromiids with at least two rostral spines include, for example, Poupiniidae Guinot, 1991 (Guinot, 1991; Feldmann et al., 1993), some Raninoida (Van Bakel et al., 2012), some Prosopidae (Laeviprosopon laeve) (Schweitzer and Feldmann, 2008b), and Bucculentidae Schweitzer and Feldmann, 2009d (Starzyk et al., 2011).

Nodoprosopon echinorum was placed in the homolid genus Tithonohomola Glaessner, 1933 by Wehner (1988) based on the presumed possession of a linea homolica. Subsequently, Schweitzer et al. (2007a) placed N. echinorum in Nodoprosopon after comparison to N. ornatum, and Feldmann and Schweitzer (2009) added that no linea homolica could be found in the holotype. However, the taxon has not been mentioned in the literature about Nodoprosopon since (see Schweitzer and Feldmann, 2009d; Schweitzer et al., 2010). The species resembles Vectis Withers, 1945, and Verrucarcinus Schweitzer and Feldmann, 2009d, in overall shape, delineation of regions, and overall ornamentation. Unfortunately, the frontal region of $N$. echinorum is not preserved. For now, we questionably retain that species in Nodoprosopon, but further study of the holotype and new specimens when available would be welcome to reevaluate its generic placement.

\section{Nodoprosopon ornatum (von Meyer, 1857)} Figure 6
1857 Prosopon ornatum von Meyer, p. 556.

1858 Prosopon spinosum von Meyer; Quenstedt, p. 779, pl. 95.37.

1860 Prosopon ornatum von Meyer; von Meyer, p. 212, pl. 23.25-23.26.

1867 Prosopon pustulatum Quenstedt, p. 315, pl. 26.13.

1889 Prosopon ornatum von Meyer; Moericke, p. 60, pl. 6.15 .

1966 Nodoprosopon ornatum carpaticum Patrulius, p. 507 , fig. 5 , pl. 30.8 .

1969 Nodoprosopon ornatum (von Meyer); Glaessner, R484, fig. 294.3.

1985 Nodoprosopon circinatum Collins in Collins and Wierzbowski, p. 76, pl. 1.1.

1988 Nodoprosopon ornatum (von Meyer); Wehner, p. 47, fig. 14, pl. 3.3-3.5.

2000 Nodoprosopon ornatum (von Meyer); Müller et al., p. 52 , figs. $6,17 \mathrm{G}$.

2007a Nodoprosopon ornatum (von Meyer); Schweitzer et al., p. 104, fig. 2.1-2.2.

2007a Nodoprosopon circinatum Collins in Collins and Wierzbowski; Schweitzer et al., fig. 2.6 (non 2.9).

2009d Nodoprosopon ornatum (von Meyer); Schweitzer and Feldmann, p. 116, fig. 10.

2012b Nodoprosopon ornatum (von Meyer); Schweitzer et al., p. 24, fig. 15.2.

2018 Nodoprosopon ornatum (von Meyer); Schweitzer et al., fig. 18.6.

2018 Nodoprosopon ornatum (von Meyer); Schweigert and Kuschel, fig. 19.

Diagnosis. See Schweitzer and Feldmann (2009d, p. 116).

Material studied. NHMW 1990/0041/0061, 1990/ 0041/0063, 1990/0041/0342, 1990/0041/0520, $1990 / 0041 / 2967, \quad 1990 / 0041 / 3160, \quad 1990 / 0041 /$ $3475, \quad 1990 / 0041 / 3513, \quad 1990 / 0041 / 4064$, 2007z0149/0010, 2014/0194/0046, 2014/0194/ 0070, 2014/0194/1007, all from the coral reef Ernstbrunn Limestone of the Ernstbrunn quarries (Google Earth coordinates: 48.54, 16.35), Austria, Late Jurassic (Tithonian) (Schweitzer and Feldmann, 2009d; Schneider et al., 2013); MAB k36133615 , from the sponge-microbial limestones of the Plettenberg quarry near Schömberg (Google Earth coordinates: 48.21, 8.81), SW Germany, Late Jurassic (late Oxfordian-early Kimmeridgian); MAB $\mathrm{k} 3616-3621$, from the sponge-microbial limestones of the Am Saufang quarry near Geisingen (Google Earth coordinates: 47.93, 8.67), SW Germany, Late Jurassic (late Kimmeridgian); SMNS 70490/13 from the bedded sponge-microbial limestones of Bad Überkingen-Oberböhringen (Google Earth 


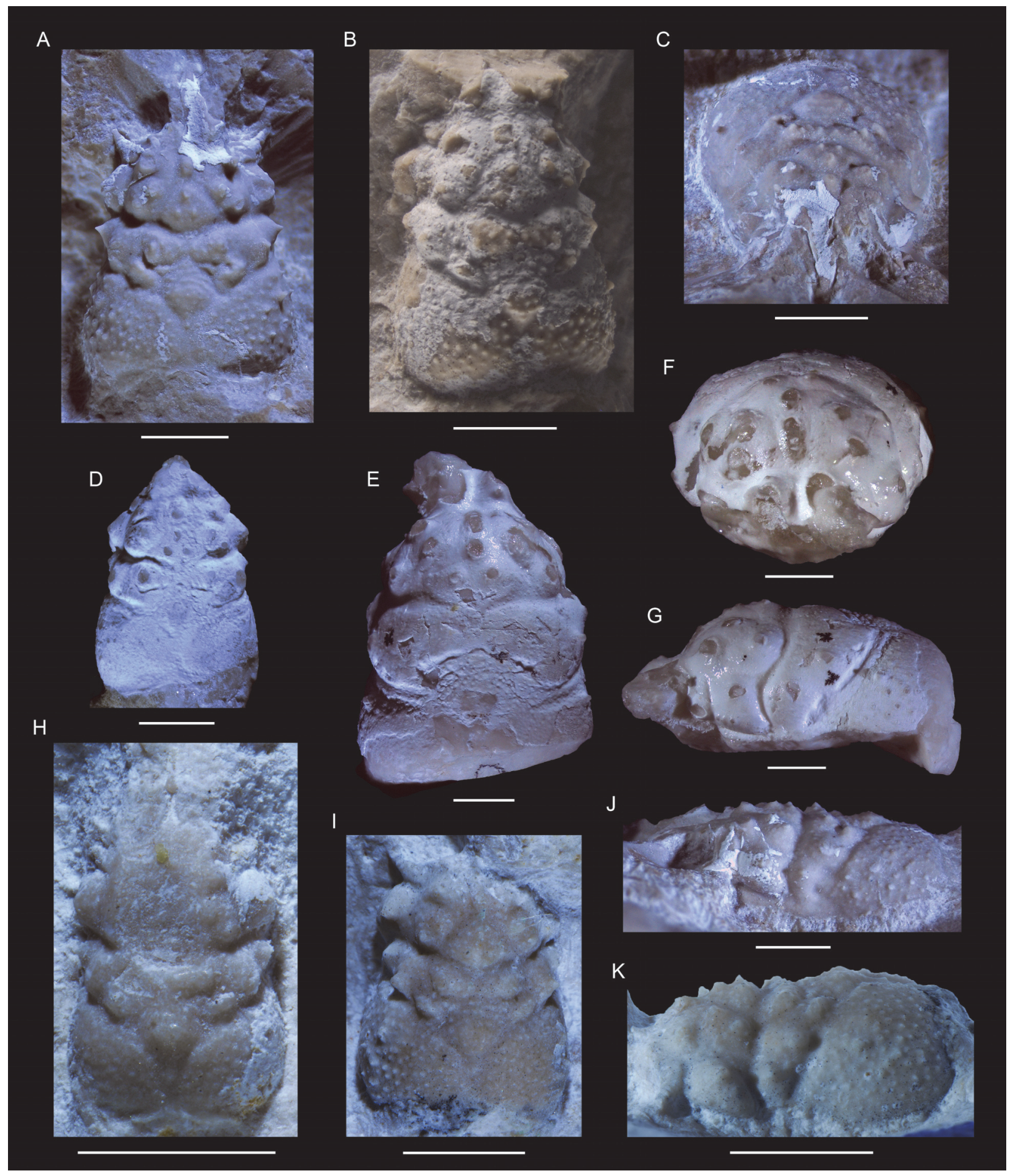

FIGURE 6. Specimens of the crab Nodoprosopon ornatum (von Meyer, 1857) from the Late Jurassic of Central Europe. Specimens originate from the late Kimmeridgian of the Am Saufang quarry near Geisingen, SW Germany (A, C, J); the late Kimmeridgian of Bad Überkingen-Oberböhringen, SW Germany (B); the Tithonian of Ernstbrunn, eastern Austria (D-G); and the Oxfordian of Bzów (H) and Ogrodzieniec (I, K), Poland. A, B, D, E, H, I, dorsal views of carapaces (MAB k3620, SMNS 70490/3, NHMW 2014/0194/1007, 1990/0041/3475, 1535-I-F/MP/1535/1509/08, 6281-IF/MP/6281/1599/12, resp.). Note central rostral spine in A, C, and H. C, F frontal views of carapaces (NHMW 1990/ 0041/3475, MAB k3620, resp.). G, J, K, left-lateral views (NHMW 1990/0041/3475, MAB k3620, 6281-I-F/MP/6281/ $1599 / 12$, resp.). Scale bar width equals $2.0 \mathrm{~mm}$. 
coordinates: 48.61, 9.79), SW Germany, Late Jurassic (late Kimmeridgian); 1332-I-F/MP/1332/ $1508 / 08$ and 1535-I-F/MP/1535/1509/08 from the sponge-microbial limestones of Bzów (Google Earth coordinates: 50.28, 19.31), Poland, Late Jurassic (Oxfordian); 6281-I-F/MP/6281/1599/12 from the sponge-microbial limestones of Ogrodzieniec (Google Earth coordinates: 50.27, 19.31), Poland, Late Jurassic (Oxfordian).

Occurrence. Late Jurassic (Oxfordian-Tithonian) of Central Europe (Austria, Czech Republic, Germany, Poland).

Dimensions. (In mm) NHMW 1990/0041/0061: max. length excl. rostrum $(L)=\sim 2.9$, max. width $(W)=2.2 ; 1990 / 0041 / 0063$ : L=-, $W=\sim 4.2 ; 1990 /$ 0041/0342: L= 8.1, W=-; 1990/0041/0520: L=-, $W=5.8 ; 1990 / 0041 / 2967: \quad L=-, \quad W=-; 1990 / 0041 /$ 3160: $L=-, \quad W=\sim 3.9 ; 1990 / 0041 / 3475: L=>9.6$, $W=7.8 ; 1990 / 0041 / 3513: L=-, W=\sim 3.7 ; 1990 / 0041 /$ 4064: $L=\sim 4.0, \quad W=3.3 ; \quad 2007 z 0149 / 0010: \quad L=-$, $W=\sim 4.9 ; 2014 / 0194 / 0046: L=-, W=-; 2014 / 0194 /$ 0070: L= 9.1, W=-; 2014/0194/1007: L= 5.4, $W=4.3 ; \quad M A B$ k3613: $L=5.5, \quad W=-; \quad k 3614: L=-$, $W=5.0$; k3615: $L=5.7, W=4.5$; $k 3616$ : $L=-, W=5.2$; k3617: $L=5.2, \quad W=3.5 ; \quad k 3618: L=4.9, \quad W=3.3$; k3619: $L=-, W=5.0 ; k 3620: L=5.9, W=4.8 ; k 3621$ : $\mathrm{L}=-, \quad \mathrm{W}=8.0 ; \quad$ 1332-I-F/MP/1332/1508/08: L=-, $\mathrm{W}=4.1 ; \quad 1535-\mathrm{I}-\mathrm{F} / \mathrm{MP} / 1535 / 1509 / 08: \quad \mathrm{L}=\sim 2.9$, $\mathrm{W}=2.2 ; \quad 6281-\mathrm{I}-\mathrm{F} / \mathrm{MP} / 6281 / 1599 / 12: \mathrm{L}=-, \quad \mathrm{W}=3.4$; SMNS 70490/1: $L=8.0, W=5.7 ; 70490 / 2: L=5.7$, $\mathrm{W}=4.3 ; 70490 / 3: \mathrm{L}=7.7, \mathrm{~W}=5.9$.

Description. Reference is made to von Meyer (1860, p. 212), translated to English by Schweitzer et al. (2007a, p. 104), and supplemental information in Wehner (1988, p. 48-49). Additionally: orbits poorly known, small portion right orbit preserved (Figure 6F), suggesting rather shallow orbit with rim and without fissures.

Remarks. The entire rostrum consisting of three spines as described by Wehner (1988, p. 48) is incomplete in all specimens (Figure 6). The anterolaterally oriented spines at the outer orbital angle were drawn previously (Wehner, 1988, figure 14), but are photographed here for the first time. The subhepatic swelling may be less protruding in larger specimens in dorsal view, and the uro-/metagastric regions are variably expressed. Two Ernstbrunn specimens (1990/0041/4064, 2014/0194/ 0070) lack the two tubercles at the base of the mesogastric region.

Wehner (1988) declared Nodoprosopon circinatum Collins in Collins and Wierzbowski, 1985, a junior synonym of $N$. ornatum after comparing the actual specimens. Schweitzer et al. (2007a) noted several differences of $N$. circinatum compared to Nodoprosopon s.s. (including $N$. ornatum), but we were not able to verify these differences after studying intraspecific variation within 13 specimens from Ernstbrunn. Thus, we agree and maintain the synonymy proposed by Wehner (1988) here.

Patrulius (1966) erected a new subspecies (Nodoprosopon ornatum carpaticum) and noted some small differences between $N$. ornatum and this taxon, including a greater number of tubercles in the anterior carapace, a smaller number of tubercles in the middle part, and the presence of tubercles on the cardiac region. Our study cannot confirm these differences. Although tubercles are usually present on the middle part of the carapace, we have also observed some specimens (NHMW 1990/0041/3475; Figure 6E) that do not carry clear tubercles there, but otherwise, appear identical to all other specimens. Thus, we do not elevate this subspecies to the species-level.

\section{Family LONGODROMITIDAE Schweitzer and Feldmann, 2009d \\ Genus ABYSSOPHTHALMUS Schweitzer and Feldmann, 2009d}

Type species. Prosopon spinosum von Meyer, 1842 , by original designation.

Included species. Abyssophthalmus adinae Schweitzer, Feldmann, Lazăr, Schweigert, and Franţescu, 2018; A. bellaii (Crônier and Boursicot, 2009), as ?Nodoprosopon; ?A. dzhafarberdensis (llyin, 2005) comb. nov., as Nodoprosopon; $A$. hebes (von Meyer, 1835), as Prosopon; A. mainense (Crônier and Boursicot, 2009), as ?Nodoprosopon; A. mirus (Moericke, 1889), as Prosopon; A. schultzi Schweitzer and Feldmann, 2009a; $A$. spinosus (von Meyer, 1842), as Prosopon; A. stotzingensis (von Meyer, 1856), as Prosopon.

?Abyssophthalmus dzhafarberdensis (Ilyin, 2005) comb. nov.

Figure 7

2005 Nodoprosopon dzhafarberdensis llyin, p. 171, fig. $35 \mathrm{C}$, pl. 7.3.

Description. See Ilyin (2005, p. 171-175).

Remarks. Nodoprosopon dzhafarberdensis Ilyin, 2005, from the Tithonian-Berriasian of Crimea, was questionably assigned to Prosopon by Schweitzer and Feldmann (2009d), but a subsequent paper indicated that placement into a longodromitid genus such as Planoprosopon or Abyssophthalmus may be better (Schweitzer et al., 2018), to which we concur. Schweitzer and Feldmann (2009d, p. 101) proposed three differences between the two genera: Abyssophthalmus would 


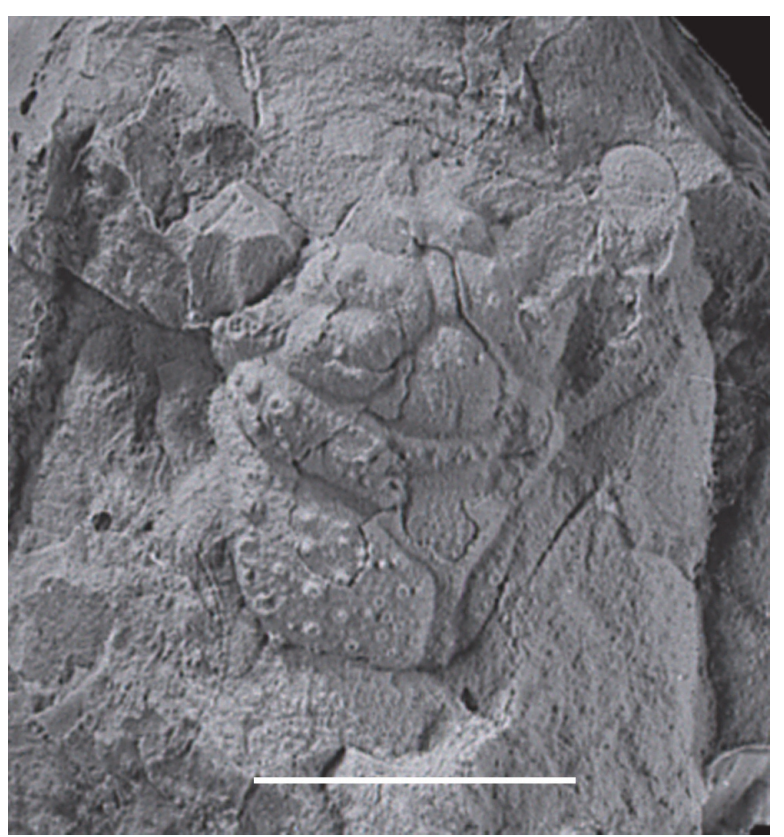

FIGURE 7. Holotype specimen of the crab ?Abyssophthalmus dzhafarberdensis (Ilyin, 2005) comb. nov. from the Late Jurassic to Early Cretaceous (Tithonian-Berriasian) of Crimea. Scale bar width equals $5.0 \mathrm{~mm}$.

be less dorso-ventrally compressed, exhibit deeper orbits, and possess stronger orbital ornamentation. Only the first difference can be used here because the depth of the orbits and ornamentation on the orbital rim are difficult to observe in $N$. dzhafarberdensis. Based on a higher resolution image than the one published in llyin (2005) (Figure 7), we tentatively ascribe the taxon to Abyssophthalmus because the dorsal surface does not appear to be very compressed. We did not use Ilyin's figure $35 \mathrm{C}$ for comparison because this drawing does not appear to accurately represent the specimen.

Abyssophthalmus cf. A. spinosus (von Meyer, 1842)

Figure 8

1842 Prosopon spinosum von Meyer, p. 71, pl. 15.115.2.

1858 Prosopon marginatum von Meyer; Quenstedt, p. 779 , pl. 95.35 .

1860 Prosopon spinosum von Meyer; von Meyer, $p$. 196, pl. 23.6-23.7.

1867 Prosopon personatum Quenstedt, p. 315, pl. 26.10.

1936 Prosopon spinosum von Meyer; Kuhn, p. 122, fig. 2.

1969 Nodoprosopon spinosum (von Meyer); Förster, p. 53, pl. 2.2.

1983 Nodoprosopon spinosum (von Meyer); Meyer and Schmidt-Kaler, fig. 21.6(8).
1985 Nodoprosopon spinosum (von Meyer); Collins and Wierzbowski, p. 80, pl. 1.6.

1988 Nodoprosopon spinosum (von Meyer); Wehner, p. 44, pls. 2.9, 3.1, 3.2.

2000 Nodoprosopon spinosum (von Meyer); Müller et al., fig. $17 \mathrm{f}$.

2009d Abyssophthalmus spinosus (von Meyer); Schweitzer and Feldmann, p. 108, fig. 8.1, 8.5-8.7.

2012b Abyssophthalmus spinosus (von Meyer); Schweitzer et al., fig. 9.1.

2018 Abyssophthalmus spinosus (von Meyer); Schweigert and Kuschel, p. 20, fig. 11.

2018 Abyssophthalmus spinosus (von Meyer); Schweitzer et al., fig. 18.1.

Diagnosis. See Wehner (1988, p. 45).

Material studied. MAB k3607-3612, from the sponge-microbial limestones at the Plettenberg quarry near Schömberg (Google Earth coordinates: 48.21, 8.81), SW Germany, Late Jurassic (late Oxfordian-early Kimmeridgian); NHMW 2014/ 0194/0952, from the coral reef Ernstbrunn Limestone of the Ernstbrunn quarries (Google Earth coordinates: 48.54, 16.35), Austria, Late Jurassic (Tithonian) (Schweitzer and Feldmann, 2009d; Schneider et al., 2013).

Occurrence. Late Jurassic (Oxfordian-Tithonian) of Europe (Austria, Germany, and Poland).

Dimensions. (In mm) NHMW 2014/0194/0952: max. length excl. rostrum $(L)=39.1$, max. width excl. projections $(W)=30.1$; $M A B$ k3607: $L=12.0$, $W=9.5 ; \quad k 3608: \quad L=-, \quad W=11.8 ; \quad k 3609: \quad L=10.1$, $W=7.6 ; \quad k 3610: \quad L=10.3, \quad W=8.2 ; \quad k 3611: \quad L=9.0$, $W=7.3$; $k 3612$ : $L=-, W=10.2$.

Description. See von Meyer (1860, p. 196) and its translation and emended description in Schweitzer and Feldmann 2009d, p. 110-111).

Remarks. The specimen represents an unusually large individual with a length width ratio of 1.30; we have found no smaller individuals in the Ernstbrunn collection that may be conspecific to this specimen. The specimen closely resembles Abyssophthalmus spinosus in many ways: the overall pattern and depth of grooves, carapace outline, the rostrum with a wide concavity axially in dorsal view, the spinose character of the anterior carapace, distinct spines on the epibranchial region, the uro-/ metagastric region that is much narrower axially, and the tubercles on the meso-metabranchial region. However, some differences also exist such as the lack of a true mesogastric process (it is a groove instead), the seemingly proportionally wider meso-metabranchial region, and the somewhat more spinose character on the anterior carapace. Moreover, the length-width ratio of the Oxfordian 


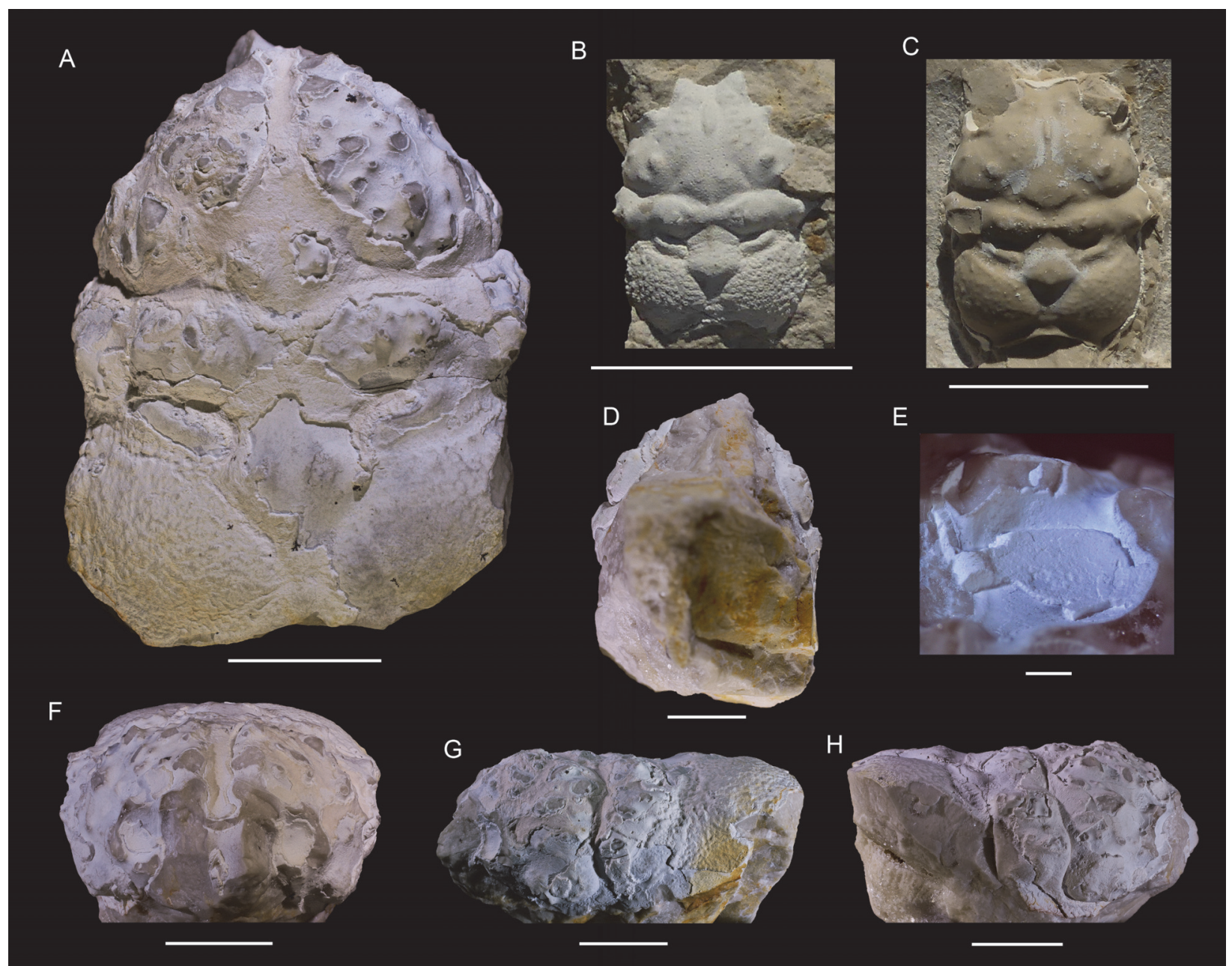

FIGURE 8. Specimen of the crab Abyssophthalmus cf. A. spinosus (von Meyer, 1842) from the Late Jurassic (Tithonian) of Ernstbrunn, eastern Austria (all except $\mathbf{B}$ and $\mathbf{C}$ ) and specimens of $A$. spinosus from the Late Jurassic (late Oxfordian-early Kimmeridgian) of the Plettenberg quarry, Germany (B, C). A, D-H, dorsal, ventral, right-orbital (shown upside down to better see depth), frontal, left-lateral, and right-lateral views, resp. (NHMW 2014/0194/0952). B, C, dorsal views (MAB k3611 and k3607). Scale bar width is $10.0 \mathrm{~mm}$, except for $\mathbf{E}(1.0 \mathrm{~mm})$.

material appears to increase as the animal grows from $\sim 1.3$ for small specimens to $\sim 1.4-1.5$ (carapace lengths of $\sim 12-19 \mathrm{~mm}$ ) (Schweitzer and Feldmann, 2009d, table 8), but this trend is not supported by data in Wehner (1988, p. 45). We refrain from erecting a new species because we cannot exclude the possibility that the differences are caused by ontogenetic change. The carapace herein is nearly twice as large as the largest one reported in Wehner (1988): $22.1 \mathrm{~mm}$ vs $39.1 \mathrm{~mm}$ length. Therefore, we tentatively assign the specimen to $A$. spinosus.

This specimen is the first record of this species from the Tithonian, if our assignment is correct. To our knowledge, this specimen represents the largest complete reported brachyuran carapace identified to the species-level from the Juras- sic thus far [compare to data in Klompmaker et al. (2015a)]. The right orbital cavity bears a vertical ridge in frontal view (Figure $8 \mathrm{E}$, left side), a feature often seen in Late Jurassic crabs (e.g., Schweitzer and Feldmann, 2009d; Starzyk, 2013; herein). Of note is that the cuticle is fully present in one part (Figure 8E, left side, middle part), but nearly absent in another part (Figure 8E, left side, lower part); this ridge becomes much less prominent in the latter case, implying that this ridge may become difficult to recognize for internal molds of some brachyurans.

Genus PLANOPROSOPON Schweitzer, Feldmann, and Lazăr, 2007a

Type species. Prosopon heydeni von Meyer, 1857 , by original designation. 


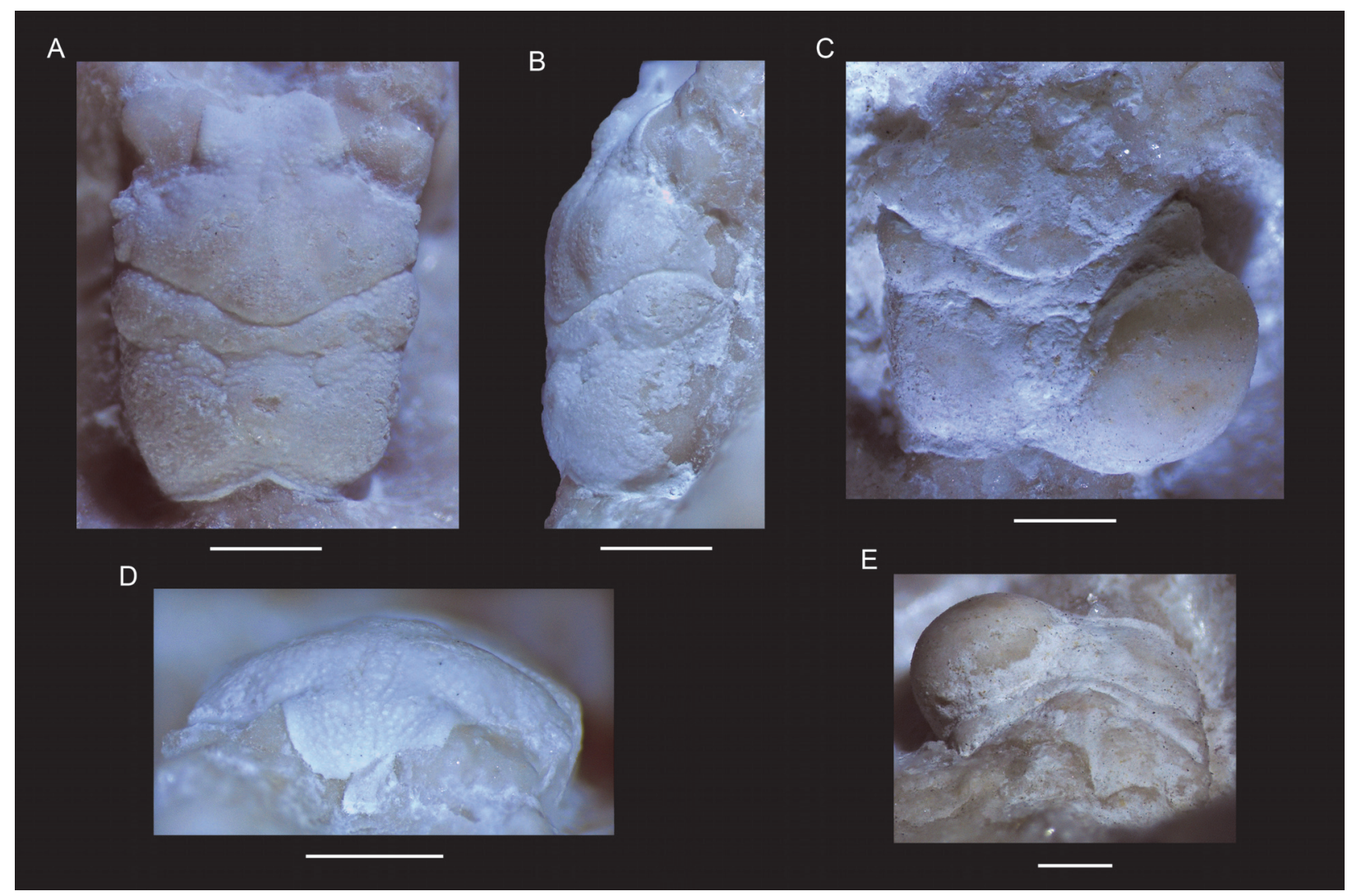

FIGURE 9. Specimens of the crab Planoprosopon aff. P. hystricosus Schweitzer and Feldmann, 2009a, from the Late Jurassic (Tithonian) of Ernstbrunn, eastern Austria. A, C, dorsal views of carapace (NHMW 2017/0089/0034 and 1990/0041/0805). B, right-lateral view (2017/0089/0034). D, E, frontal views (2017/0089/0034 and 1990/0041/0805). Note the presence of an epicaridean parasite swelling (ichnotaxon Kanthyloma crusta Klompmaker et al., 2014) in the right branchial region in 1990/0041/0805. Scale bar width equals $1.0 \mathrm{~mm}$.

Included species. Planoprosopon aequus (von Meyer, 1857), as Prosopon; P. conspicuus Schweitzer, Lazăr, Feldmann, Stoica, and Franţescu, 2017; P. cornutus (Wehner, 1988), as Nodoprosopon; P. dumosus (Wehner, 1988), as Nodoprosopon; P. heydeni (von Meyer, 1857), as Prosopon; P. hystricosus Schweitzer and Feldmann, 2009a; $P$. kashimaensis Kato, Takahashi, and Taira, 2010; $P$. major (Hée, 1924); $P$. ogawaense Karasawa and Hirota, 2019; P. quadratum Schweigert and Koppka, 2011; P. rhathamingus Schweitzer and Feldmann, 2009a; $P$. sarumaru Karasawa and Hirota, 2019; P. schweigerti Schweitzer and Feldmann 2009b.

Planoprosopon aff. P. hystricosus Schweitzer and Feldmann, 2009a

Figure 9

2009a Planoprosopon hystricosus Schweitzer and Feldmann, p. 219, fig. 4.4-4.6.

Diagnosis. See Schweitzer and Feldmann (2009a, p. 220).
Material studied. NHMW 1990/0041/0805, 1990/ 0041/1614, 1990/0041/4221b, 2017/0089/0034.

Occurrence. Coral reef Ernstbrunn Limestone of the Ernstbrunn quarries (Google Earth coordinates: 48.54, 16.35), Austria, Late Jurassic (Tithonian) (Schweitzer and Feldmann, 2009d; Schneider et al., 2013).

Dimensions. (In mm) NHMW 2017/0089/0034: max. length excl. rostrum $(L)=3.0$, max. width excl. projections $(W)=2.7 ; 1990 / 0041 / 0805$ : $L=-, W=3.3$; 1990/0041/1614: $L=\sim 2.0, \quad W=\sim 1.8 ; 1990 / 0041 /$ 4221b: $L=\sim 3.0, W=\sim 2.5$.

Description. See Schweitzer and Feldmann (2009a, p. 220-221).

Remarks. This species has been figured only in dorsal view; we here provide frontal and lateral views for the first time using a newly discovered specimen. Schweitzer and Feldmann (2009a) provided images of three specimens of this species measuring 2.8, 3.7, and $11.8 \mathrm{~mm}$ in length excluding the rostrum. The differences from the smallest two figured versus the largest specimen include: 
(1) change in the course of the cervical groove from broadly $\mathrm{V}$-shaped to more sinuous with a middle segment, (2) development of large tubercles in the hepatic-protogastric region, (3) increase of the proportional length of the meta/urogastric region, (4) the epibranchial region becomes less swollen laterally, (5) position of maximum width becomes located more anteriorly, and (6) the length-width ratio increases. These changes were attributed to allometric growth (Schweitzer and Feldmann, 2009a). The number and types of changes are quite remarkable for crabs, however. For example, brachyuran carapaces usually become proportionally wider instead of longer through ontogeny as shown quantitatively (e.g., Barnes, 1968; Davidson and Marsden, 1987; Negreiros-Fransozo et al., 2003; Klompmaker et al., 2012, 2015b; GómezCruz et al., 2015; but see Finney and Abele, 1981, for the opposite). A change from a carapace with small tubercles to a combination of small and large tubercles is uncommon in crabs. More specimens of intermediate size are needed to confirm whether all specimens of the type series are truly conspecific. The specimens under study resemble the paratypes more closely than the holotype, so we questionable assign these specimens to Planoprosopon aff. $P$. hystricosus.

One of the three studied specimens contains a swelling in the right branchial region (Figure 9C, $\mathrm{E})$, almost certainly caused by an epicaridean isopod parasite, as seen in modern decapods (e.g., Williams and Boyko, 2012; An et al., 2015). Such swellings are referred to the ichnotaxon Kanthyloma crusta Klompmaker, Artal, Van Bakel, Fraaije, and Jagt, 2014 [see also Klompmaker and Boxshall (2015)]. This is the first record of Kanthyloma in this species.

Family PROSOPIDAE von Meyer, 1860

Included genera. Acareprosopon Klompmaker, 2013a; Europrosopon gen. nov.; Laeviprosopon Glaessner, 1933; Nipponopon Karasawa, Kato, and Terabe, 2006; Prosopon von Meyer, 1835; Protuberosa Schweitzer and Feldmann, 2009d; Rathbunopon Stenzel, 1945.

Remarks. The crab Rathbunopon was originally placed in Prosopidae by Stenzel (1945), which was followed by others (Withers, 1951; Wright and Collins, 1972; Müller et al., 2000; Collins, 2002; Karasawa et al., 2006), while Bishop (1986) was unsure about placement of the genus in his list. However, Schweitzer et al. (2010) and Karasawa et al. (2011) moved Rathbunopon within Glaessneropsidae in an entirely different superfamily, Glaessneropsoidea. Karasawa et al. (2011, p. 538) briefly explained this change was based on "carapace proportions and the ornamentation and conformation of the orbits." Subsequently, Klompmaker et al. (2011) included Rathbunopon in Prosopidae again based on its close similarity to what is now known as Europrosopon, a fit with the diagnosis of Prosopidae in Schweitzer and Feldmann (2009d), and the presence of an augenrest in Rathbunopon, a feature that would be characteristic of prosopids (but see some species of Laeviprosopon). Subsequent papers by Guinot (2019) and Collins et al. (2020) kept Rathbunopon in Glaessneropsidae, but others favored placement in Prosopidae (González-León et al., 2016; Ossó et al., 2018). Schweitzer et al. (2012b, 2018, p. 326-327) maintained placement in Glaessneropsidae and provided a more detailed explanation providing only differences in orbital characters. Given the close morphological similarity of Rathbunopon and Europrosopon, placement in two different superfamilies would imply dramatic convergent evolution. Hence, further study is in order. We studied Rathbunopon obesum (Van Straelen, 1944), Europrosopon aculeatum (von Meyer, 1857), and E. abbreviatum (Schweitzer and Feldmann, 2009d) anew and affirm that nearly any character other than the orbital structure is similar, including the shape and delimitation of regions on the dorsal and lateral sides, a swollen subhepatic region, and the triangular shape and orientation of the rostrum (Figure 10). Differences exist in the orbital structure, but, overall, they appear less prominent than proposed. The outer orbital angle possesses a laterally oriented spine in Europrosopon, while a forwardly oriented projection with a wider base is present in Rathbunopon on the lateral side of the orbital structure; as a consequence, the orbital structure may appear wider and slightly more anterolaterally directed in Europrosopon. A ridge is present within the orbital structure in Europrosopon, but this feature is less prominent in Rathbunopon. Similarities of the orbital structure include the presence of a lower orbital projection that is similar in shape (although the one in Rathbunopon may be more pronounced), and both taxa possess a tubercle on the upper orbital margin. Rather than extreme convergent evolution of the entire carapace except for some parts of orbital structure justifying placement in different superfamilies, a much simpler explanation is that Rathbunopon and Europrosopon are more closely related and best placed in the same family. Regarding differences in orbits, recent work has shown that remarkable variation can be found within genera in the expression of the margins and 


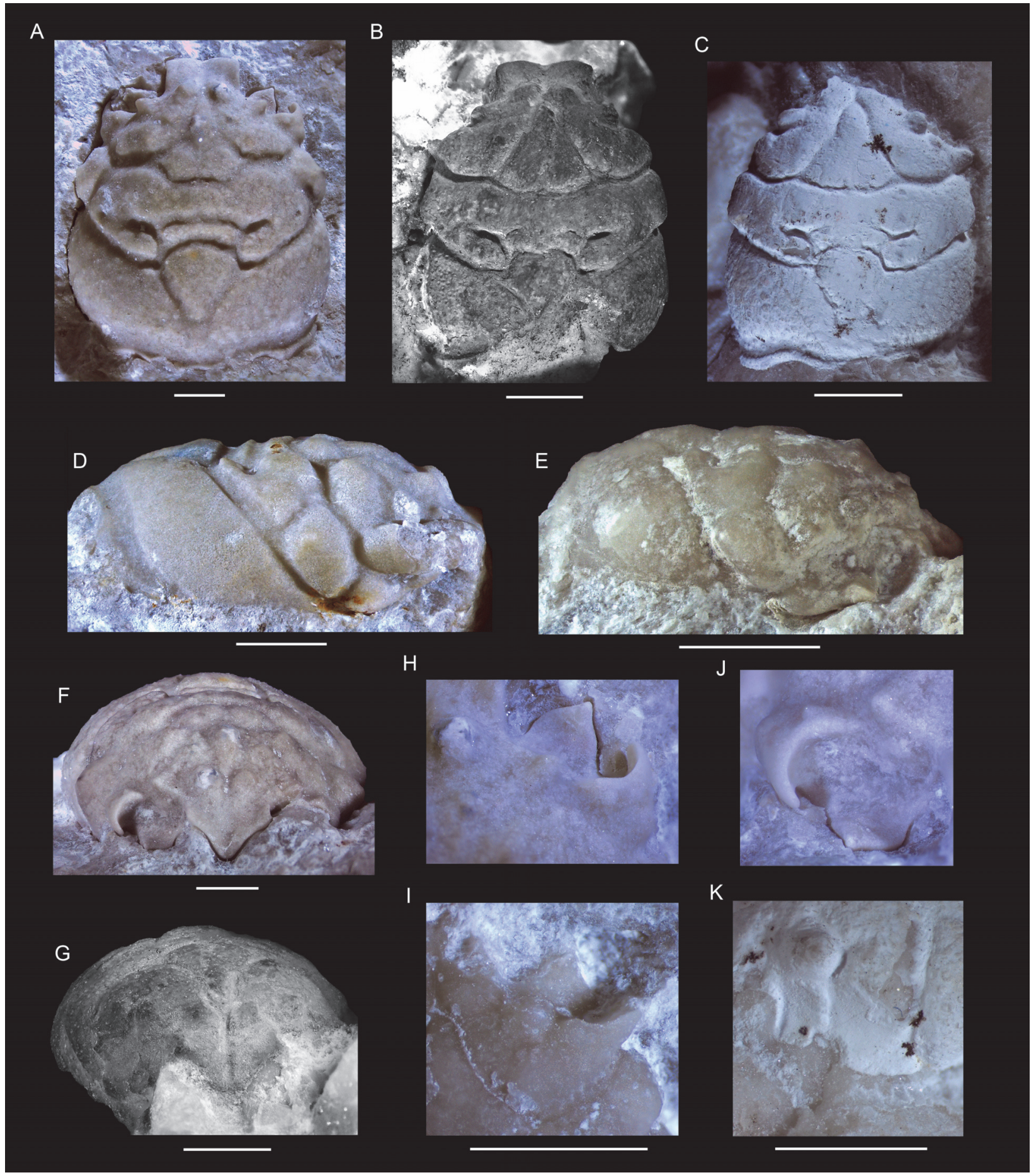

FIGURE 10. Comparisons between specimens of the mid-Cretaceous crab Rathbunopon obesum (Van Straelen, 1944) from Koskobilo, Spain, and the crab Europrosopon aculeatum (von Meyer, 1857) from Ernstbrunn, eastern Austria (Tithonian, NHMW numbers), and the Kotouc quarry (locality 3 of level 6), Czech Republic (Tithonian, MAB and UF numbers). A, F, H, J, dorsal, frontal, upper orbital, and orbital views of $R$. obesum (MAB k3600). B, G, dorsal and frontal views of $E$. aculeatum (NHMW/1990 0041/4059). C, K, dorsal and orbital view of E. aculeatum (NHMW 2007z0149/0005). D, right-lateral view of $R$. obesum (MAB k3141). E, right-lateral view of E. aculeatum (MAB k3605). I, upper orbital view of E. aculeatum (UF 288756). For approximate size of $\mathbf{H}$ and $\mathbf{J}$, see $\mathbf{A}$ and $\mathbf{F}$. Scale bar width equals $2.0 \mathrm{~mm}$. 
shape of the orbital structure (e.g., Starzyk, 2015b, 2016; herein), implying that considerable variation may also be expected within families. Guinot (2019: p. 764) found the groove just anterior to it to represent a striking feature, but also the ovoid carapace shape, the triangular rostrum, the welldefined and elevated regions, the metagastric and urogastric regions that are parallel and linear, and the deep and wide grooves. However, most or all these features can also be found in Prosopon and particularly in Europrosopon. The placement of genera currently classified within Glaessneropsidae resembling Rathbunopon, such as Ekalakia Bishop, 1976, and Vectis, requires a restudy as well, both genera originally being placed in Prosopidae (Withers, 1945; Bishop, 1976). Much hinges on whether the orbital structure of Ekalakia and Glaessneropsis Patrulius, 1959, are linked phylogenetically as proposed by Feldmann et al. (2008) or whether the similar-looking orbital structure of both taxa is an example of convergent evolution.

$$
\text { EUROPROSOPON gen. nov. }
$$

\section{zoobank.org/A7050696-60FF-4E8B-AAC7-6591CAEAE746}

Type species. Prosopon aculeatum von Meyer, 1857 (=Prosopon verrucosum Reuss, 1858).

Included species. Europrosopon abbreviatum (Schweitzer and Feldmann, 2009d) comb. nov., as Prosopon; E. aculeatum (von Meyer, 1857) comb. nov. (=Prosopon verrucosum Reuss, 1858, and Prosopon barbulescuae Schweitzer, Feldmann, Lazăr, Schweigert, and Franţescu, 2018).

Diagnosis. Carapace excluding rostrum about as wide as long or slightly longer than wide (I/w ratios 1.0-1.1), ovate to subsquare. Widest point at midlength or posteriorly. Outer orbital structure spine directed outward. Main grooves generally welldeveloped. Mesogastric region not strongly subdivided. Urogastric region separated from metagastric region. No deep groove separating epibranchial region from metagastric region. Small tubercles present across carapace.

Etymology. Contraction of euro and Prosopon, where euro refers to the fact that all known species thus far are found in Europe. Gender is neuter.

Remarks. This genus differs from other genera by a combination of a relatively low length-width ratio of the carapace compared to Acareprosopon, Laeviprosopon, Prosopon, and Protuberosa; a less nodose anterior carapace than Nipponopon, Prosopon, Protuberosa, and Rathbunopon; a lack of a strong groove separating the epibranchial region from metagastric region, which is the case for Prosopon, Protuberosa, and Rathbunopon; and a urogastric region separated from the metagastric region, which is not clearly observed in Acareprosopon, Laeviprosopon, Nipponopon, Prosopon, and Protuberosa.

Europrosopon aculeatum (von Meyer, 1857) comb. nov.

Figures 11, 12

zoobank.org/19380D4D-A956-4270-A9EA-B0BBB5CF7255

1857 Prosopon aculeatum von Meyer, p. 556.

1858 Prosopon verrucosum Reuss, p. 11.

1858 Prosopon marginatum von Meyer, 1842; Quenstedt, p. 779, pl. 95.34.

1859 Prosopon verrucosum Reuss; Reuss, p. 70, pl. 24.1.

1860 Prosopon aculeatum von Meyer; von Meyer, p. 211, pl. 23.24.

1867 Prosopon marginatum von Meyer; Quenstedt, p. 315, pl. 26.9.

1964 Prosopon verrucosum Reuss; Bachmayer, fig. 130.

1966 Prosopon verrucosum Reuss; Patrulius, fig. 1B.

1988 Prosopon aculeatum von Meyer; Wehner, p. 17, fig. 6, pl. 1.1-1.2.

2000 Prosopon aculeatum von Meyer; Müller et al., fig. 17A.

2009d Prosopon verrucosum Reuss; Schweitzer and Feldmann, p. 71-73, fig. 2.7, 2.8, 2.11, 2.12.

2009d Prosopon aculeatum von Meyer; Schweitzer and Feldmann, p. 74-75, fig. 2.10.

2012b Prosopon verrucosum Reuss; Schweitzer et al., fig. 10.1c.

2013b Prosopon verrucosum Reuss; Klompmaker, fig. $1 \mathrm{~A}$.

2016 Prosopon verrucosum Reuss; Hyžný and Zorn, p. 130, pl. 2.7a-b.

2016 Prosopon verrucosum Reuss; Klompmaker, fig. 2 (left).

2018 Prosopon barbulescuae Schweitzer, Feldmann, Lazăr, Schweigert, and Franţescu, p. 327-328, fig. 13.

2018 Prosopon verrucosum Reuss; Schweitzer et al., fig. 18.8 .

Diagnosis. Carapace (excluding rostrum) longer than wide (I/w ratio $\sim 1.1-1.3)$, ovoid, proportionally wider in larger individuals; usually widest at epibranchial regions in small specimens, widest at meso-/metabranchial regions in large specimens; strongly convex transversely, moderately longitudinally. Entire carapace covered with small tubercles on internal mold, slightly larger tubercles on cuticle. Material studied. NHMW 1990/0041/0033, 1990/ 0041/0034, 1990/0041/1690, 1990/0041/2110, 1990/0041/2516, 1990/0041/2520, 1990/0041/ 3071 , 1990/0041/3205, 1990/0041/3756, 1990/ 


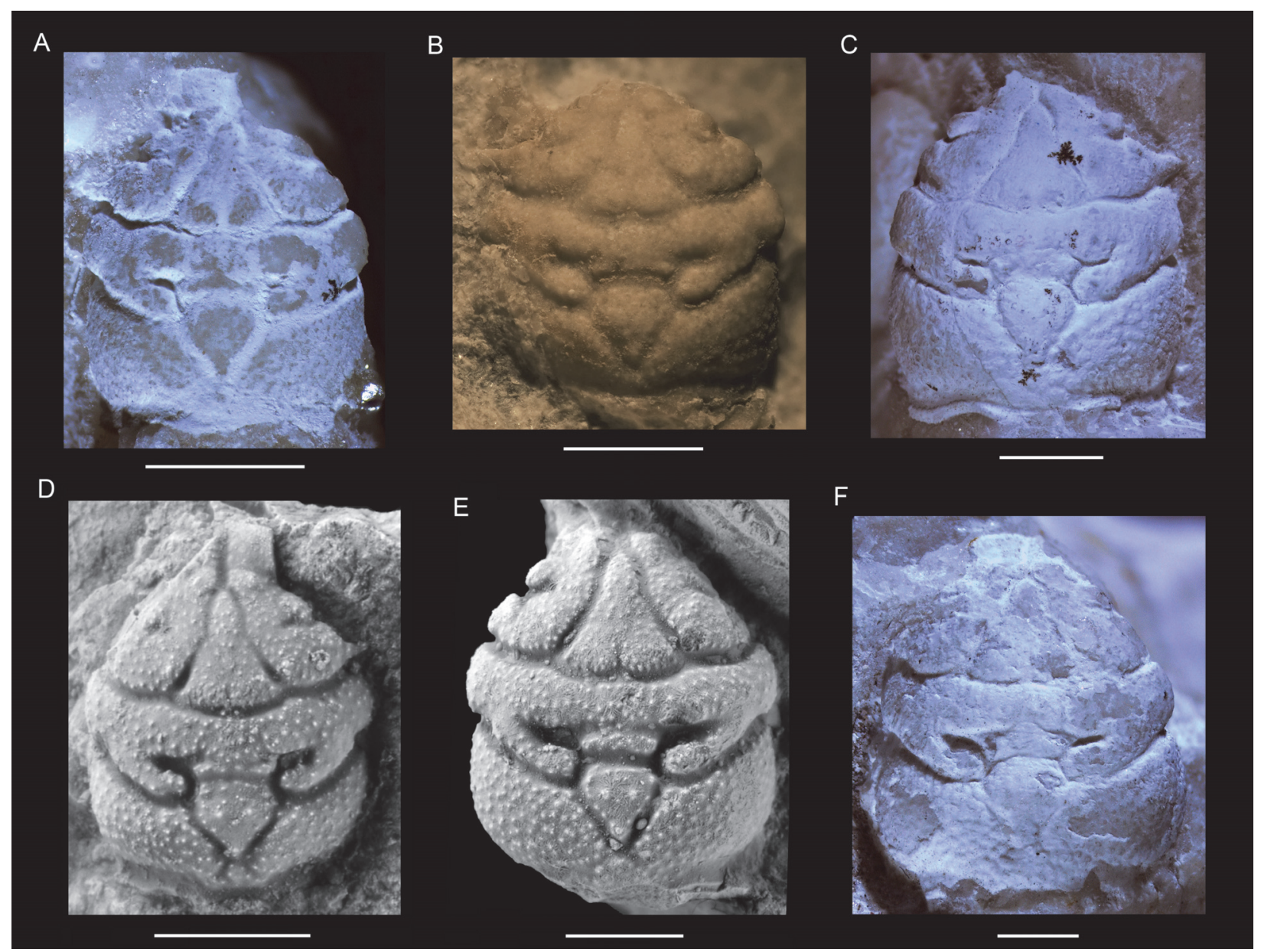

FIGURE 11. Specimens of the crab Europrosopon aculeatum (von Meyer, 1857) comb. nov. from the Late Jurassic (Tithonian) of Central Europe, all dorsal views. A, C, F, Specimens from Ernstbrunn, Austria (NHMW 1990/0041/3756, 2007z0149/0005, and 1990/0041/2520, resp., previously identified as Prosopon verrucosum by Schweitzer and Feldmann (2009d). B, Specimen (UF 288714) from the Kotouc quarry (locality 3 of level 6), Czech Republic. D, E, Specimens (LPBIII art 279 and LPBIII art 278, resp.) from Waypoint 162, Romania, previously identified as Prosopon barbulescuae (modified from Schweitzer et al., 2018, figure 13, reproduced with permission). Those images are not published under the terms of the CC-BY license of this article. For permission to reuse, please see Schweitzer et al. (2018). Note that the specimen in D is oriented toward the anterior portion of the carapace. Scale bar width equals 2.0 $\mathrm{mm}$.

$0041 / 3961, \quad 1990 / 0041 / 4059, \quad 1990 / 0041 / 4908$ 2007z0149/0003, 2007z0149/0004, 2007z0149/ 0005: coral reef Ernstbrunn Limestone of the Ernstbrunn quarries (Google Earth coordinates: 48.54, 16.35), Austria, Late Jurassic (Tithonian) (Schweitzer and Feldmann, 2009d; Schneider et al., 2013); UF 288714, 288756: coral reef Štramberk Limestone of locality 3 at level 6 of the Kotouč quarry (Google Earth coordinates: 49.583, 18.116), Czech Republic, Late Jurassic (late early Tithonian) (Vašíček and Skupien, 2016; Vašíček et al., 2018).

Occurrence. Late Jurassic of Central Europe. Tithonian of Austria, Czech Republic, and Romania; Kimmeridgian of Germany.
Dimensions. (In mm) NHMW 1990/0041/0033: max. length excl. rostrum $(L)=\sim 5.5$, max. width excl. projections $(W)=\sim 4.8 ;$ 1990/0041/0034: $\mathrm{L}=\sim 7.4, \quad \mathrm{~W}=5.8 ; \quad 1990 / 0041 / 1690: \mathrm{L}=\sim 7.0, \quad \mathrm{~W}=-$; 1990/0041/2110: L=7.3, W=6.2; 1990/0041/2516: $\mathrm{L}=5.7, \quad \mathrm{~W}=4.7 ; \quad 1990 / 0041 / 2520: \quad \mathrm{L}=8.2, \quad \mathrm{~W}=7.3$; 1990/0041/3071: $\quad L=\sim 4.4, \quad W=\sim 3.6 ; \quad 1990 / 0041 /$ 3205: $L=-, \quad W=\sim 4.1 ; \quad 1990 / 0041 / 3756: \quad L=4.5$, $\mathrm{W}=3.5 ; \quad 1990 / 0041 / 3961: \quad \mathrm{L}=9.6, \quad \mathrm{~W}=8.2 ; \quad 1990 /$ 0041/4059: $\quad L=7.9, \quad W=6.4 ; \quad 1990 / 0041 / 4908$ : $\mathrm{L}=\sim 2.1, \quad \mathrm{~W}=\sim 1.8 ; \quad 2007 z 0149 / 0003: \quad \mathrm{L}=\sim 14.6$, $\mathrm{W}=13.7 ; \quad 2007 z 0149 / 0004: \quad \mathrm{L}=\sim 14.4, \quad \mathrm{~W}=12.7 ;$ 2007z0149/0005: L=6.5, $W=5.8 ; \quad U F \quad 288714$ : $\mathrm{L}=\sim 4.0, \mathrm{~W}=\sim 3.5 ; 288756: \mathrm{L}=\sim 4.4, \mathrm{~W}=\sim 3.6$. 


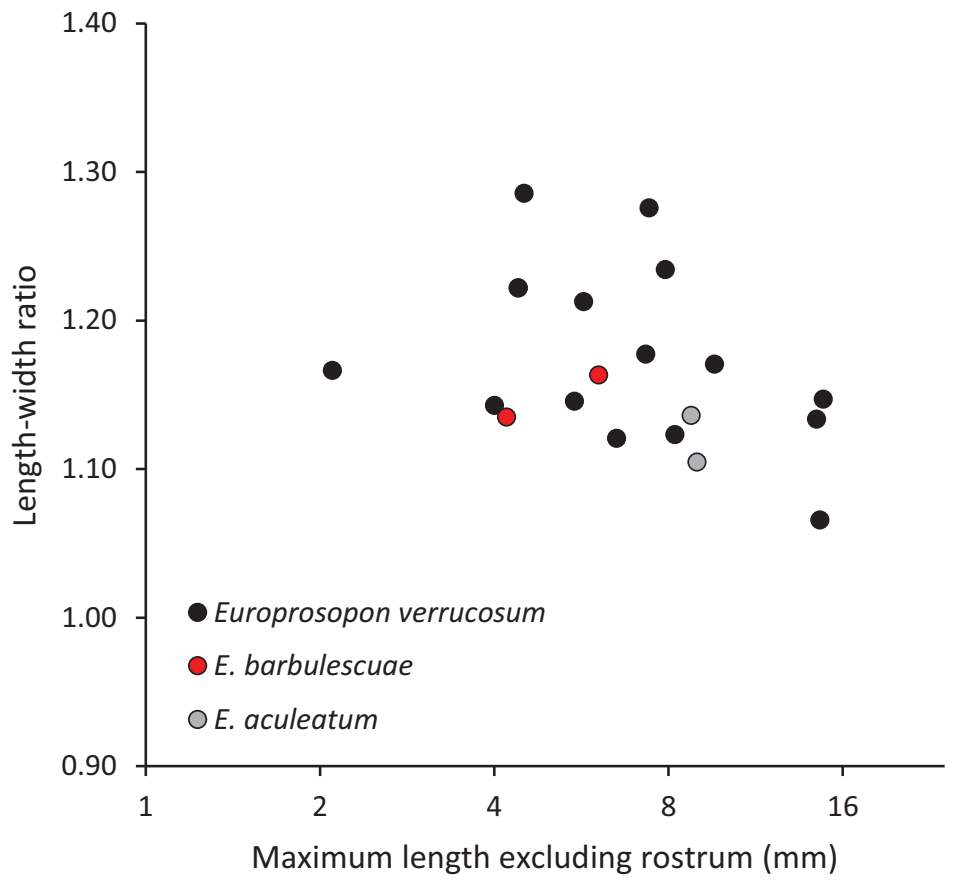

FIGURE 12. Comparison of length-width ratios relative to specimen size for carapaces of three previously recognized brachyuran species that are synonymized herein: Europrosopon aculeatum (=E. verrucosum and E. barbulescuae). Specimens grew proportionally wider (allometric growth). Data: Appendix 4.

Description. Carapace (excluding rostrum) longer than wide (I/w ratio $\sim 1.1-1.3$ ), ovoid, proportionally wider in larger individuals; usually widest at epibranchial regions in small specimens, widest at meso-/metabranchial regions in large specimens; strongly convex transversely, moderately longitudinally. Rostrum downturned, with axial groove, triangular in frontal view, with fairly wide base. Orbital cavity shallow, anterolaterally oriented, with vertical ridge within with augenrest lateral to it; orbital rim with laterally oriented spine at outer orbital angle, modest triangular projection at lower orbital margin, one large node marked by groove posteriorly at upper orbital margin. Epigastric regions marked by subcircular swellings. Protogastric and hepatic regions confluent, protogastric regions may contain weak tubercle adjacent to mesogastric region. Subhepatic regions slightly swollen. Mesogastric region pyriform, well-delineated, may contain short axial groove at base. Metagastric region wide, curving around post-cervical groove, weakly separated from epibranchial regions. Urogastric region as wide as maximum width cardiac region, short but wide, best delineated posteriorly and laterally. Cardiac region triangular to pentagonal, with three small tubercles on internal mold. Meso-/metabranchial regions confluent, with rounded lateral mar- gins. Small intestinal region defined anteriorly. Posterior margin with wide rim and two concavities. Grooves well-developed. Cervical groove sinuous, with two pits near axis. Post-cervical groove best defined in lateral portion, straight to slightly curving forward laterally. Branchiocardiac groove nearly parallel to cervical groove in lateral portion, where it curves forward to merge with cervical groove. Entire carapace covered with small tubercles on internal mold, slightly larger tubercles on cuticle. Weak posterior gastric muscle scars may be present at base mesogastric region on internal mold. Ventral surface, abdomen, and appendages unknown.

Remarks. Wehner (1988) was aware of the close similarity between Europrosopon aculeatum and $E$. verrucosum, but she decided not to synonymize the two taxa because of lack of comparative material of $E$. verrucosum. Wehner (1988, p. 19) mentioned that the anterior part of $E$. verrucosum seems to be shorter, and that "the two small, oblique elevations between the cardiac and urogastrical regions" of E. aculeatum would be different. Furthermore, Schweitzer and Feldmann (2009d) mentioned that $E$. verrucosum would have a much longer metagastric region and that $E$. aculeatum had nodes on the protogastric regions, 
which would be absent in E. verrucosum. The arguments that the anterior part of $E$. verrucosum would be shorter and that its metagastric region would be proportionally longer is not supported by the data we gathered (see Appendix 3). The oblique elevations on the urogastric region as drawn by von Meyer (1860, plate 23.24) and Wehner (1988, figure 6$)$ are more horizontally oriented in the actual specimens (Wehner, 1988, plate 1.11.2). Similar elevations can also be seen in some specimens ascribed to $E$. verrucosum (Schweitzer and Feldmann, 2009d, figure 2.8; Klompmaker, $2013 \mathrm{~b}$, figure $1 \mathrm{~A}$ ). Finally, fairly similar nodes on the protogastric regions can also be seen in some specimens of $E$. verrucosum (Bachmayer, 1964, figure 130; Schweitzer and Feldmann, 2009d, figure 2.8; Klompmaker, 2013b, figure 1A). Stratigraphically, the taxa are not separated by much (upper Kimmeridgian for $E$. aculeatum versus Tithonian for $E$. verrucosum) and both taxa are found in Central Europe. Thus, we consider E. verrucosum to represent a junior synonym of $E$. aculeatum.

Recently, Schweitzer et al. (2018) erected Prosopon barbulescuae based on two specimens from the Tithonian of Romania, mentioned to differ mainly from congenerics by having its widest point at the epibranchial regions rather than at the confluent meso-/metabranchial regions, which was also noted by Guinot (2019). However, the specimens of this taxon are smaller compared to figured coeval specimens of $E$. aculeatum $(=E$. verrucosum) (e.g., Schweitzer and Feldmann, 2009d, figure 2; Hyžný and Zorn, 2016, plate 2.7a-b). Given that many brachyurans, including goniodromitids, become proportionally wider as the animal grows, in particular by allometric growth of the meso-/metabranchial region (e.g., Klompmaker et al., 2012), this raises the question as to whether $P$. barbulescuae is juvenile of $E$. aculeatum. We reexamined the material ascribed to $E$. verrucosum by Schweitzer and Feldmann (2009d) plus some additional specimens. We find that the length-width ratios of $P$. barbulescuae fall within the range of $E$. aculeatum (E. verrucosum), and that width increases faster than length as the crab grows (allometric growth) (Figure 12, Appendix 4). Moreover, small specimens identified as $E$. verrucosum are usually widest at the epibranchial regions (Figure 11A, B, NHMW 1990/0041/3071), whereas larger specimens are consistently wider at the meso-/metabranchial regions (Figure 11F). Schweitzer et al. (2018, p. 328) mentioned other differences between $E$. verrucosum and $P$. barbulescuae: stronger spines on the upper margin of the augenrest for $P$. barbulescuae, the epigastric region of $E$. verrucosum would be square instead of ovoid, the postcervical groove would bend concave forwardly in the lateralmost portion in E. verrucosum rather than being straight, and the cardiac region of $E$. verrucosum would be longer. These minor, possible differences are absent to inconsistent across all studied specimens previously ascribed to $E$. verrucosum. Thus, we consider $P$. barbulescuae to represent a junior synonym of $E$. aculeatum (=E. verrucosum).

\section{Genus LAEVIPROSOPON Glaessner, 1933}

Type species. Prosopon laeve von Meyer, 1857, by original designation.

Included species. Laeviprosopon crassum Klompmaker, 2013a; L. fraasi (Moericke, 1889), as Prosopon; L. grandicentrum Schweitzer and Feldmann, 2008b; L. hispanicum Klompmaker, 2013a; L. icaunensis (Van Straelen, 1936), as Prosopon; L. laeve von Meyer, 1857; L. laculatum Schweitzer and Feldmann, 2008b; L. lazarae Franţescu, 2011; L. musialiki Starzyk, 2020; L. planum Klompmaker, 2013a; L. edoi Klompmaker, 2013a; L. punctatum (von Meyer, 1857), as Prosopon; L. sublaeve (von Meyer, 1857), as Prosopon.

\section{Laeviprosopon punctatum (von Meyer, 1857)} Figure 13

1857 Prosopon punctatum von Meyer, p. 556.

1860 Prosopon punctatum von Meyer; von Meyer, p. 210, pl. 23.23.

1889 Prosopon punctatum von Meyer; Moericke, $p$. 62, pl. 6.23.

1969 Laeviprosopon laeve punctatum (von Meyer); Glaessner, R484, fig. 294.2.

1988 Prosopon punctatum von Meyer; Wehner, p. 23, fig. 8, pl. 1.5-1.6.

2000 Prosopon punctatum von Meyer; Müller et al., fig. 17C.

2008b Laeviprosopon punctatum (von Meyer); Schweitzer and Feldmann, p. 280-281, fig. 1.7.

2012b Laeviprosopon punctatum (von Meyer); Schweitzer et al., p. 17, fig. 10.2c.

Diagnosis. See Schweitzer and Feldmann (2008b, p. 281).

Material studied. NHMW 2017/0089/0033, from the coral reef Ernstbrunn Limestone of the Ernstbrunn quarries (Google Earth coordinates: 48.54, 16.35), Austria, Late Jurassic (Tithonian) (Schweitzer and Feldmann, 2009d; Schneider et al., 2013).

Dimensions. (In $\mathrm{mm}$ ) maximum length excl. rostrum $=\sim 8.6$, maximum width $=6.9$. 


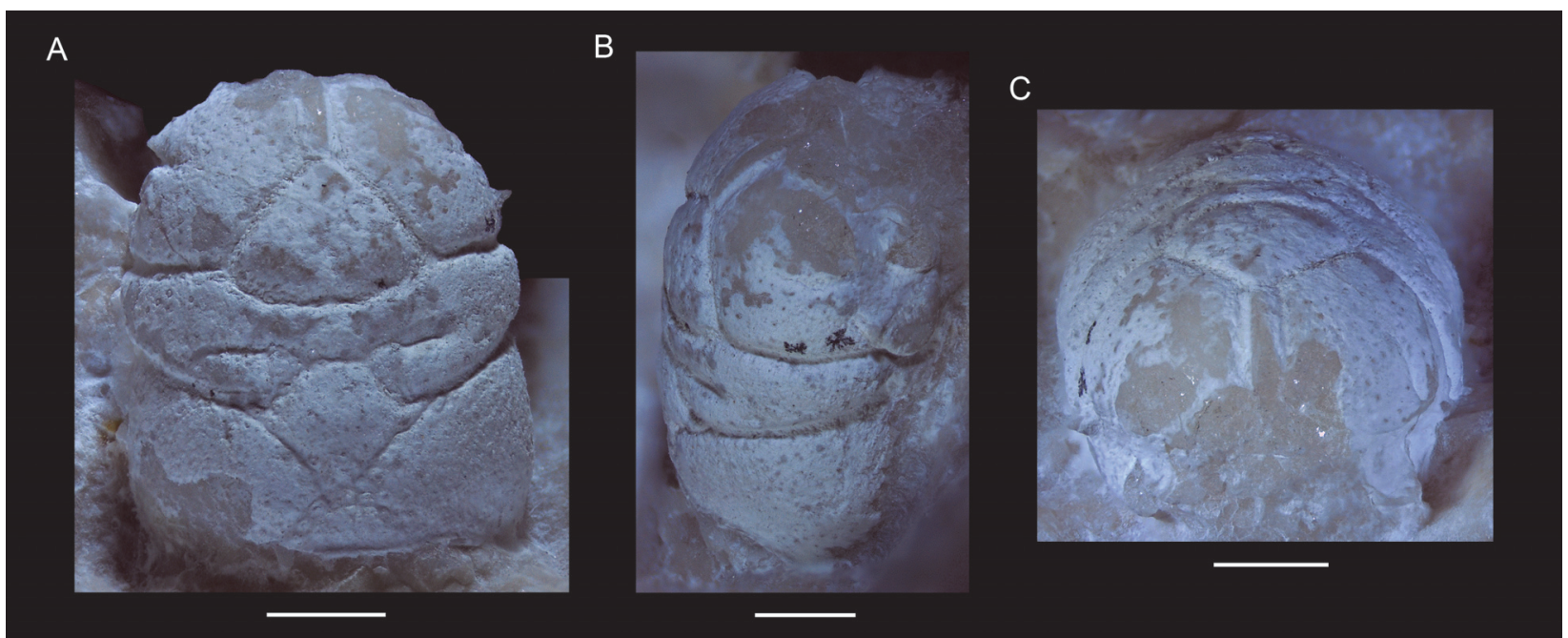

FIGURE 13. Specimen of the crab Laeviprosopon punctatum (von Meyer, 1857) (NHMW 2017/0089/0033) from the Late Jurassic (Tithonian) of Ernstbrunn, eastern Austria. A, dorsal view of carapace. B, right-lateral view. C, frontal view. Scale bar width equals $2.0 \mathrm{~mm}$.

Occurrence. Late Jurassic (Kimmeridgian-Tithonian) of Central Europe (Austria, Czech Republic, Germany).

Description. Reference is made to von Meyer (1860, p. 210-211), translated to English in Schweitzer and Feldmann (2008b, p. 281). Additional characters: orbital cavity shallow, anterolaterally oriented; small outer orbital spine directed transversely. Subhepatic region swollen.

Remarks. This species has been reported from the late Kimmeridgian type locality Örlinger Tal near UIm in SW Germany (von Meyer, 1860), while the neotype is from the Tithonian of Chotěbuz (Kotzobenz), Czech Republic (Moericke, 1889; Wehner, 1988; Müller et al., 2000). Moericke (1889) also listed this taxon from the Tithonian of Racziechowy in Poland. Furthermore, Wehner (1988) mentioned the species' presence in late Kimmeridgian-early Tithonian localities of Germany. More recently, this species was also listed in a conference abstracts as originating also from the late Kimmeridgian of Geislingen an der Steige and Saal an der Donau, southern Germany (Schweigert et al., 2016; Schweigert, 2019). The specimen figured herein from the Tithonian of the Ernstbrunn quarries in eastern Austria represents a new occurrence. The figured specimen was found among previously uncatalogued material from Ernstbrunn and represents the only specimen known from this region, consistent with its low abundance in other localities (von Meyer, 1860; Moericke, 1889; Wehner, 1988). A carapace of this species has not been photographed in lateral and frontal views thus far, which we provide herein.
Genus PROSOPON von Meyer, 1835

Type species. Prosopon tuberosum von Meyer, 1840 , by original designation.

Included species. Prosopon jocosum Thurmann in Étallon, 1861; P. josephcollinsi sp. nov.; P. mammillatum Woodward, 1868; $P$. tuberosum von Meyer, 1840.

Diagnosis. Carapace longer than wide (I/w ratio $\sim 1.1-1.4$ ), rectangular to trapezoid in outline, widest at posterior part or at mid-length. Anterior carapace with large nodes, with two nodes at base mesogastric region. Main grooves generally welldeveloped. Clear groove separating epibranchial region from metagastric region usually present. Small tubercles present on at least part of carapace.

Remarks. Given that multiple species have been removed from this genus herein compared to Schweitzer et al. (2018), we provide a new diagnosis.

Prosopon josephcollinsi sp. nov.

Figure 14

zoobank.org/738A9151-07FA-4659-997A-069F5B821578

Diagnosis. Carapace longer than wide (I/w ratio 1.15), rectangular to trapezoid in dorsal view, widest at branchial region, bulbous appearance anteriorly. Rostrum downturned, with broad base, triangular in frontal view. Mesogastric region pyriform, well-delineated, with two strong nodes posteriorly along axis. Mesobranchial region divided from swollen epibranchial region by strong groove. Tubercles primarily present on anterior carapace and on lateral parts posterior carapace. 


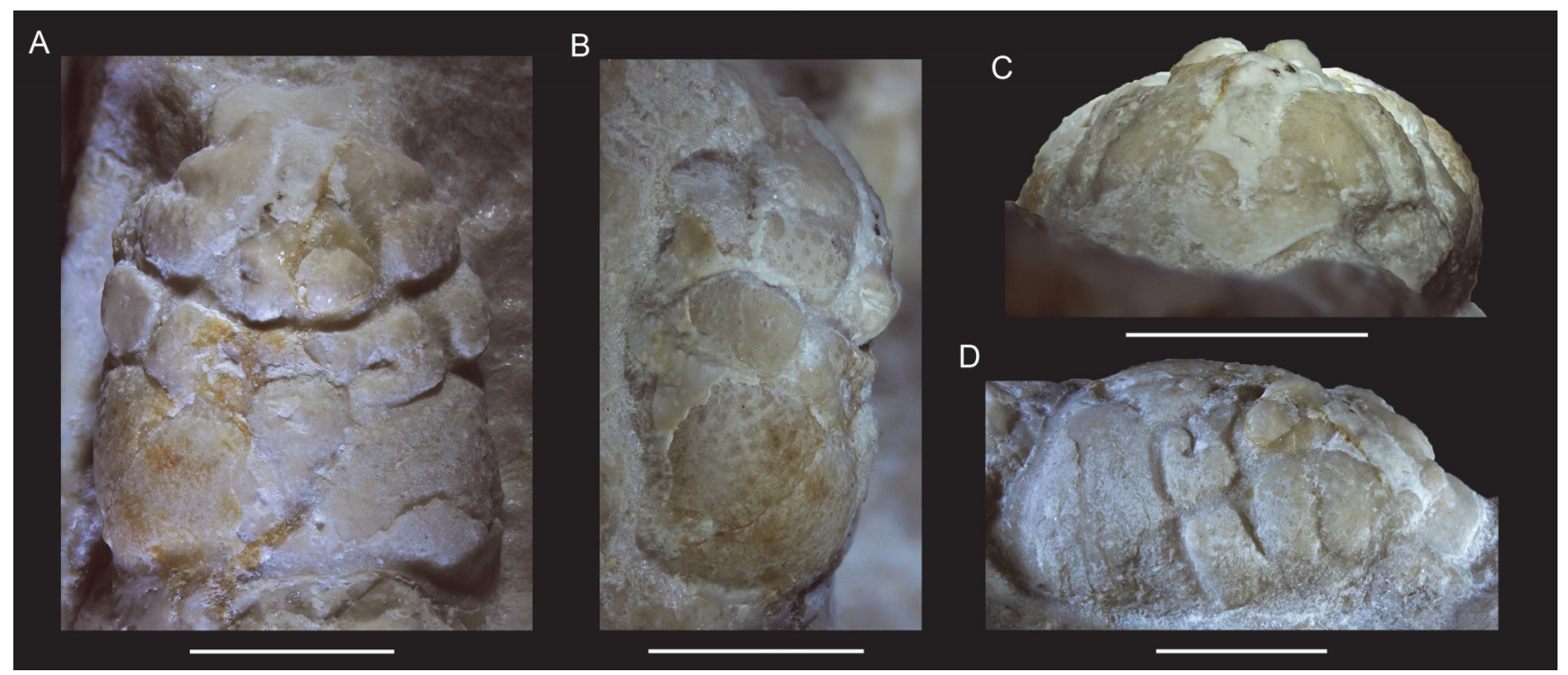

FIGURE 14. Specimen of the crab Prosopon josephcollinsi sp. nov. (NHMW 1990/0041/0738) from the Late Jurassic (Tithonian) of Ernstbrunn, eastern Austria. A, dorsal view of carapace. B, left-lateral view. C, frontal view. D, right-lateral view, angled. Scale bar width equals $5.0 \mathrm{~mm}$.

Etymology. Named after Joseph S.H. Collins (scientific associate of the Natural History Museum in London until he passed away in 2019), for a lifetime of work on fossil crustaceans, particularly Brachyura.

Material studied. Holotype and sole specimen: NHMW 1990/0041/0738.

Occurrence. Coral reef Ernstbrunn Limestone of the Ernstbrunn quarry "Werk II" (Google Earth coordinates: $\sim 48.54, \sim 16.35)$, Austria, Late Jurassic (Tithonian) (Schweitzer and Feldmann, 2009d; Schneider et al., 2013).

Dimensions. (In mm) NHMW 1990/0041/0738: max. length excl. rostrum $(L)=11.4$, max. width $(\mathrm{W})=9.9$.

Description. Carapace longer than wide (I/w ratio 1.15), rectangular to trapezoid in dorsal view, widest at branchial region, strongly convex transversely, weakly-moderately longitudinally, bulbous appearance anteriorly. Lateral margins rounded, slightly diverging posteriorly. Posterior margin bounded by groove, with two slight concavities. Flanks fairly tall. Rostrum downturned, with broad base, triangular in frontal view. Orbital structure not exposed. Epigastric region consisting of two circular swellings. Protogastric and hepatic regions divided by oblique groove. Mesogastric region pyriform, well-delineated, with two strong nodes posteriorly along axis. Uro-metagastric region fairly narrow, confluent with mesobranchial region that is divided from swollen epibranchial region by strong groove. Cardiac region pentagonal in shape with tip pointing posteriorly, somewhat inflated anteri- orly. Metabranchial region largest. Intestinal region not visible. Grooves generally deep, with cervical groove widely U-shaped. Cervical and branchiocardiac grooves paralleling each other in dorsal view except on axial part, merging on flank around epibranchial region. Post-cervical groove marks anterior border of cardiac region, ends in deep pit lateral to cardiac region. Tubercles primarily present on anterior carapace and on lateral parts posterior carapace. No clear muscle scars visible. Cuticle present around tip of mesogastric region, on posterior part right metabranchial region, and partly on left flank. Appendages, ventral surface, and abdomen unknown.

Remarks. For comparison to the type species, Prosopon tuberosum from the "Neocomian" (earliest Cretaceous, Berriasian-Hauterivian) of eastern France, we assumed that the drawing accurately reflects the specimen, which has not been located and is presumed to have been lost (Wehner, 1988; Schweitzer and Feldmann, 2009d). Prosopon josephcollinsi sp. nov. bears more tubercles on the antero-lateral and anterior portion of the carapace on its internal mold, which tends to have fewer tubercles than the cuticle (see Klompmaker et al., 2015c); has somewhat narrower branchial regions for this similar-sized specimen; and the nodes on the posterior part of the mesogastric region are more pronounced. Prosopon jocosum from the Kimmeridgian of Switzerland was described based on two syntypes, figures of which can be found online (science.mnhn.fr/taxon/species/prosopon/ jocosum). One specimen (MNHN.F.A29786) is 


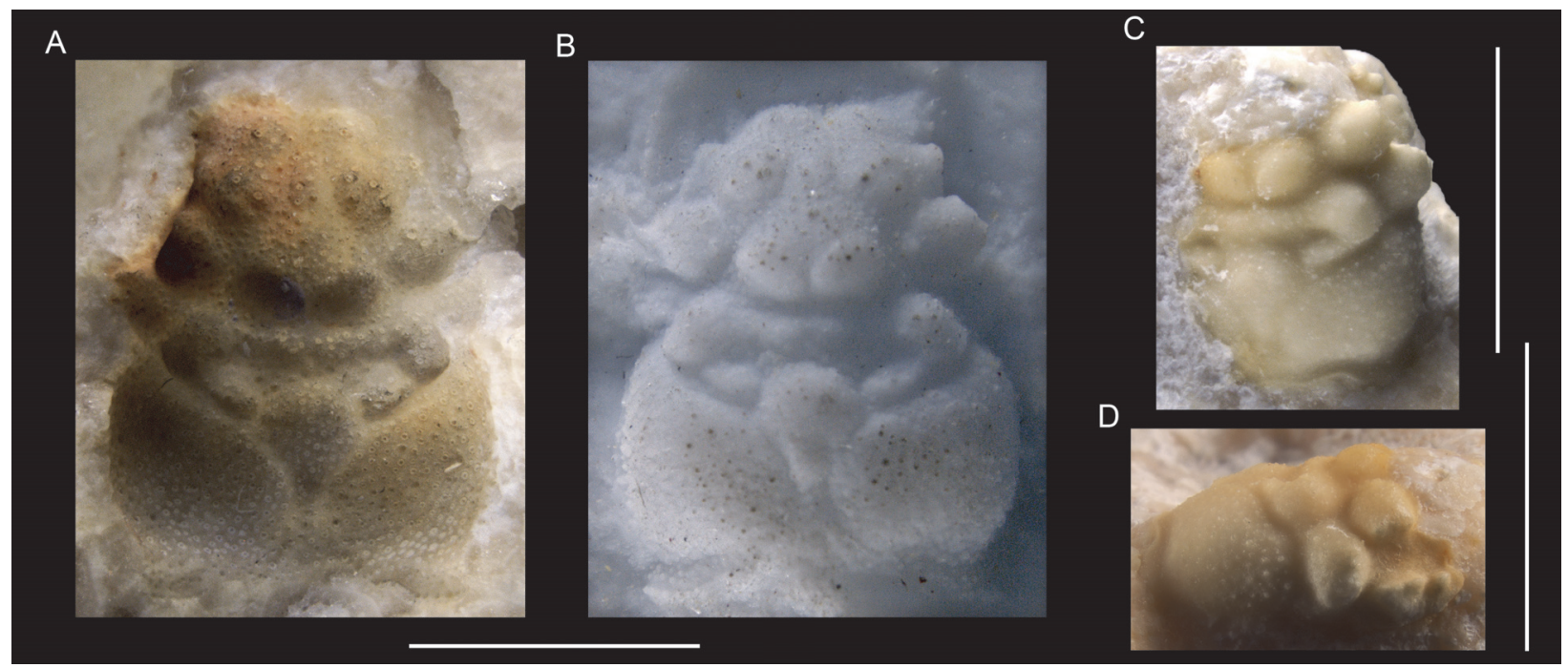

FIGURE 15. Holo- and paratype of the crab Protuberosa protuberosa (Wehner, 1988) from the Late Jurassic (late Kimmeridgian) of Saal near Kelheim, southern Germany. A, B, dorsal views of carapace of holotype (SNSB-BSPG 2016 XXI 482) (external mold and cast, resp.). C, dorsal view of partial carapace of paratype (SNSB-BSPG 2016 XXI 484). D, right-lateral view of paratype. Scale bar width equals $5.0 \mathrm{~mm}$.

clearly deformed anteriorly so that length-width ratio is lower than in reality, but its rostrum appears narrower as preserved and with a strong axial groove unlike $P$. josephcollinsi sp. nov. The other specimen (MNHN.F.A29787), of comparable length to $P$. josephcollinsi sp. nov., has a much higher length-width ratio than the new species ( 1.38 vs $\sim 1.15$ ). Prosopon mammillatum from the Bathonian of England (see also Withers, 1951) does not have a clear groove separating epibranchial region from metagastric region and bears smaller nodes on the posterior part of the mesogastric region.

\section{Genus PROTUBEROSA Schweitzer and Feldmann, 2009d}

Type and sole species. Prosopon protuberosum Wehner, 1988, by monotypy.

Protuberosa protuberosa (Wehner, 1988)

Figure 15

1988 Prosopon protuberosum Wehner, p. 20, fig. 7, pl. 1.3-1.4.

2000 Prosopon protuberosum Wehner; Müller et al., fig. 17B.

2009d Protuberosa protuberosa Wehner; Schweitzer and Feldmann, p. 77, fig. 2.9.

Diagnosis. Carapace widening posteriorly, longer than wide (I/w ratio $\sim 1.2)$. Very bulbous appearance anterior to branchiocardiac groove, in particular mesobranchial, epibranchial, base mesogastric, protogastric, and hepatic regions. Ridge with two tubercles on flank. Tubercles scattered across carapace, often with pit in center.
Material studied. Holotype: SNSB-BSPG 2016 XXI 482; paratype: SNSB-BSPG 2016 XXI 484.

Occurrence. Coralgal "Kelheimer Schuttkalk" of Saal an der Donau near Kelheim, southern Germany (Google Earth coordinates: 48.88, 11.94), Late Jurassic (late Kimmeridgian), see Wehner (1988).

Dimensions. (In mm) Holotype SNSB-BSPG 2016 $X X I$ 482: max. length excl. rostrum but incl. epigastric swellings $(L)=\sim 8.3$, max. width $(W)=\sim 6.7$; paratype SNSB-BSPG 2016 XXI 484: L=-, W=6.0.

Description. Referral is made to Wehner (1988, p. 20-21) and the English translation in Schweitzer and Feldmann (2009d, p. 77).

Remarks. These two type specimens were housed in the private Sylla collection, but were recently purchased by the Bayerische Staatssammlung für Paläontologie und Geologie, Munich, Germany. Now the specimens have become available for research, a restudy is warranted. We refigure the specimens including the lateral side of the paratype for the first time, showing a peculiar ridge with tubercles (Figure 15D) that was only drawn previously (Wehner, 1988, figure 7B).

Recently, Guinot (2019) suggested removing Protuberosa from Prosopidae and hypothesized relatedness to Bucculentidae. Given the strong similarity of Protuberosa to prosopids, Guinot (2019) implied substantial convergent evolution of the carapace of Protuberosa towards prosopids if Protuberosa indeed would be a bucculentid. However, Bucculentum is widest at the hepatic region, 
has a spiny to three-pronged rostrum, and does not possess a concavity on the lateral side anterior of the cervical groove as seen in other prosopids (e.g., Starzyk et al., 2011; Schweitzer and Feldmann, 2009d; Schweitzer et al., 2018). As Protuberosa does not appear to differ much from other prosopids (see also Figures 11-14), we maintain Protuberosa within Prosopidae.

\section{Family TANIDROMITIDAE Schweitzer and Feldmann, 2008a \\ Genus TANIDROMITES Schweitzer and}

Feldmann, 2008a

Type species. Prosopon insigne von Meyer, 1857, by original designation.

Included species. Tanidromites aequilatus (von Meyer, 1857), as Prosopon; T. alexandrae Starzyk, 2015a; T. etalloni (Collins in Collins and Wierzbowski, 1985), as Coelopus; T. hyznyi (Starzyk, 2015b), as Eodromites; T. insignis (von Meyer, 1857), as Prosopon; T. lithuanicus Schweigert and Koppka, 2011; T. Ionginosa Starzyk, 2016; T. maerteni Fraaije, Van Bakel, Guinot, and Jagt, 2013; T. montreuilense Crônier and Boursicot, 2009; T. muelleri Krobicki and Zatoń, 2016; T. nightwishorum sp. nov.; T. pustulosa (von Meyer, 1860), as Pithonoton; T. raboeufi Robin, Van Bakel, d'Hondt, and Charbonnier, 2015; T. richardsoni (Woodward, 1907), as Prosopon; T. scheffnerae Schweigert and Koppka, 2011 (=T. wysokaensis Starzyk, 2016); T. sculpta (Quenstedt, 1858), as Prosopon (=Prosopon lingulata von Meyer, 1858; Prosopon wuergauensis Kuhn, 1939); T. schweitzerae Starzyk, 2016; T. starzykae Schweitzer, Feldmann, Lazăr, Schweigert, and Franţescu, 2018; T. weinschenki sp. nov.

Remarks. Morphological differences between Tanidromites scheffnerae and T. wysokaensis are mentioned to include the rostrum being more sharply ended for $T$. scheffnerae (Starzyk, 2016). However, the rostrum is incomplete or not prepared fully for all figured specimens (including all types) of $T$. wysokaensis nor in any of the other available specimens (pers. obs. NS). None of the specimens from Ernstbrunn have the rostrum fully preserved either. Tanidromites scheffnerae would have mesogastric groove tubercles said to be absent in T. wysokaensis (Starzyk, 2016). However, figure 4.1 in Starzyk (2016) indicates the presence of such a tubercle in $T$. wysokaensis and a re-examination of paratype (I-F/MP/6263/1588/ 11) also reveals such tubercles. No new differences were found upon a re-examination of one Polish Oxfordian specimen of each species ( $T$. wysokaensis: I-F/MP/6263/1588/11; T. scheff- nerae: I-F/MP/6261/1588/11). Because the orbital structure, one of the prime characters to distinguish species within Tanidromites (Starzyk, 2013, 2015a, 2016), is also identical, we consider $T$. wysokaensis as a junior synonym of $T$. scheffnerae.

Although the highly deformed holotype of $T$. schweitzerae has a shape, groove structure, and groove depth similar to $T$. alexandrae, Starzyk (2016) mentioned the more extended lower orbital margin, a short and blunt rostrum, and the elongated, less rounded epibranchial regions of $T$. schweitzerae to represent differences. The strong extension of the lower orbital margin can, at least in part, be explained by the fact that the orbital structure contains fractures resulting in this margin being flipped more forwardly. A blunt tip of the rostrum is also seen in T. alexandrae, and re-examination of the holotype of $T$. schweitzerae does reveal a hepatic pit, as found for $T$. alexandrae. The mesogastric groove tubercles are not always discernible for $T$. alexandrae either. The less rounded shape of the epibranchial region may be attributed to the deformed nature of the holotype because the paratype I-F/MP/4562/1534/08 of $T$. schweitzerae is indeed more rounded. These similarities beg the question whether $T$. schweitzerae is a junior synonym of $T$. alexandrae. A key difference remaining is the upper orbital margin that appears smooth in $T$. schweitzerae but contains some tubercles in $T$. alexandrae. Furthermore, the extension of the lower orbital margin in $T$. schweitzerae appears more prominent than in $T$. alexandrae despite the deformation that enhances this difference. Finally, although size is often not appropriate to use as a difference between species, it is notable that two of three specimens of $T$. schweitzerae, though incomplete, are larger (see Starzyk, 2016, table 1) than all 23 specimens of $T$. alexandrae with maximum carapace length of $9.6 \mathrm{~mm}$ (Starzyk, 2015a). Small, complete specimens of T. schweitzerae are required to further assess differences and similarities for similar-sized specimens because the relatively small specimen (I-F/MP/ $4562 / 1534 / 08$ ) is incomplete and indented near the left hepatic region and orbital structure. Until then, we maintain the two species separate.

Tanidromites scheffnerae Schweigert and Koppka, 2011

Figure 16

2011 Tanidromites scheffnerae Schweigert and Koppka, p. 230, fig. 8.

2013 Tanidromites scheffnerae Schweigert and Koppka; Starzyk, p. 180, figs. 3, 6. 


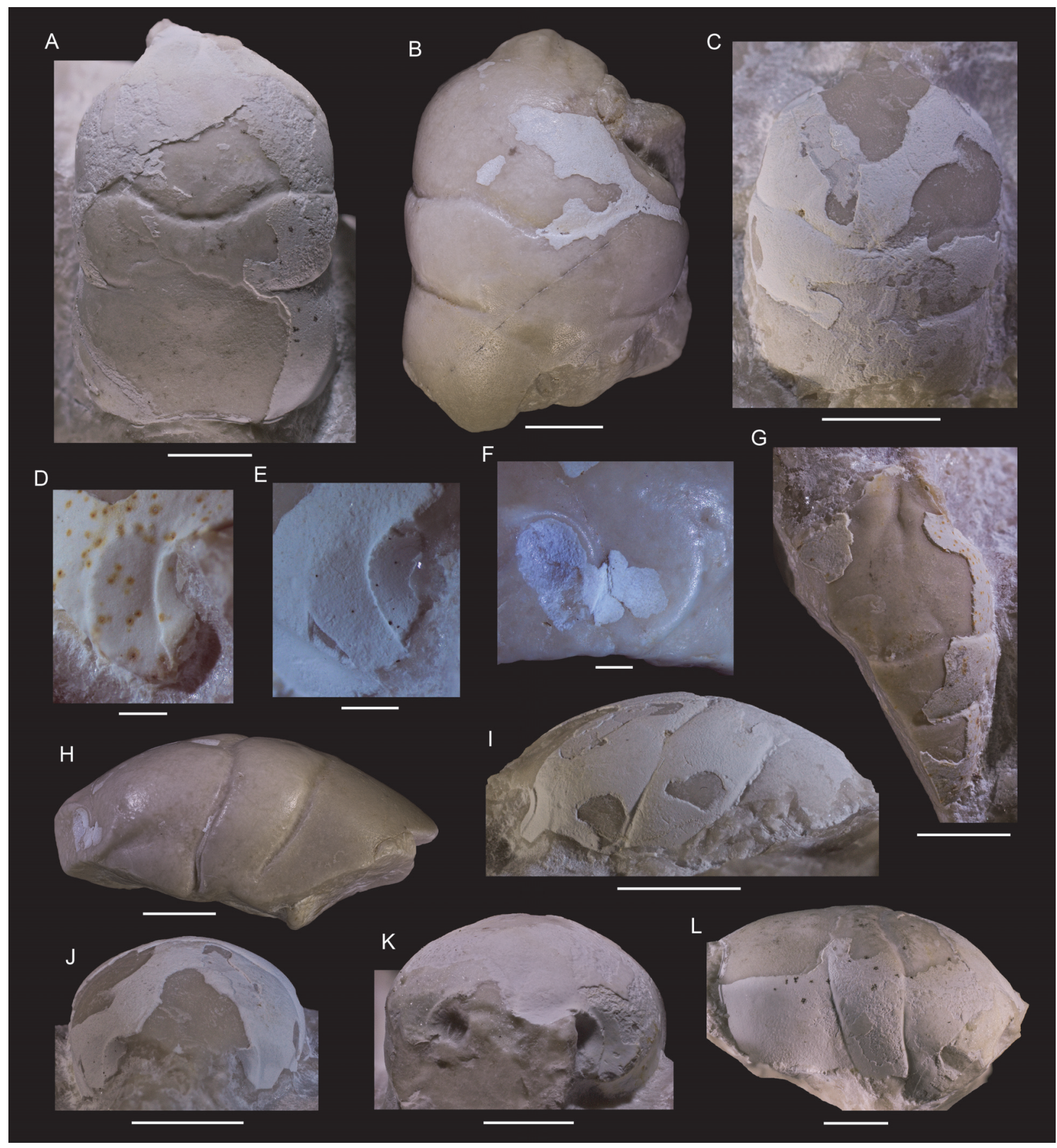

FIGURE 16. Specimens of the crab Tanidromites scheffnerae Schweigert and Koppka, 2011, from the Late Jurassic (Tithonian) of Ernstbrunn, eastern Austria. A-C, G, dorsal views (NHMW 2014/0194/0988, 2014/0194/0314, 2014/ 0194/0312, and 1990/0041/1318, resp.). D-F, two left and one right views of augenrest (NHMW 1990/0041/1318, 2014/0194/0312, and 2014/0194/0314, resp.). H, I, L, two left- and one right-lateral views (NHMW 2014/0194/0314, 2014/0194/0312, and 2014/0194/0988, resp.). J, K, frontal views (NHMW 2014/0194/0312 and 2014/0194/0988, resp.). Scale bar width is $5.0 \mathrm{~mm}$, except for $\mathbf{D}-\mathbf{F}(1.0 \mathrm{~mm})$.

2016 Tanidromites wysokaensis Starzyk, p. 7, figs. 2, 4.

Diagnosis. Species with large maximum size ( 27 $\mathrm{mm}$ in length), length (without rostrum)-width ratio $\sim 1.5$, moderately-strongly convex transversely and longitudinally. Distance from outer orbital angle to cervical groove long (0.3-0.4 x length rostrum to cervical groove). Rostrum with sharp tip. Augenrest rounded, flat, and short (length about $0.6 \mathrm{x}$ width); outer orbital spine absent. Mesogastric groove 
tubercles present. Lateral margins very rounded, paralleling in dorsal view. Cuticle and internal mold without to very limited ornamentation (modified from Starzyk, 2013, p. 180, after restudy, with major changes in italics).

Material studied. NHMW 1990/0041/1318, 1990/ 0041/3962, 2014/0194/0312, 2014/0194/0314, 2014/0194/0988: Late Jurassic (Tithonian) specimens from coral reef limestones of the Ernstbrunn Limestone, Ernstbrunn quarries, Austria (Google Earth coordinates: 48.54, 16.35) (Schweitzer and Feldmann, 2009d; Schneider et al., 2013); I-F/MP/ 6261/1588/11: Late Jurassic (Oxfordian) specimen from sponge-microbial limestones at Wysoka (Google Earth coordinates: 50.25, 19.21); I-F/MP/ 6263/1588/11 (=paratype T. wysokaensis): Late Jurassic (Oxfordian) specimen from sponge-microbial limestones at Niegowonice (Google Earth coordinates: $50.23,19.26$ ).

Occurrence. Late Jurassic of Central Europe: middle-late Oxfordian of southern Poland (Starzyk, 2013, 2016; herein), late Kimmeridgian of southern Germany (Schweigert and Koppka, 2011), Tithonian of eastern Austria (herein).

Dimensions. (In mm) NHMW 1990/0041/1318: max. length excl. rostrum but incl. epigastric swellings $(L)=>16.5$, max. width $(W)=12.2 ; 1990 / 0041 /$ 3962: $L=\sim 25.0, W=\sim 16.8 ; 2014 / 0194 / 0312: L=>$ 13.7, $W=10.6 ; 2014 / 0194 / 0314: L=>26.0, W=18.3$; 2014/0194/0988: L= 23.7, W=16.0.

Description. See Schweigert and Koppka (2011, p. 230) and Starzyk (2013, p. 180-182). Additionally: hepatic pits arranged in a circle (antennar extensor muscle scars), as in Eodromites (Starzyk, 2015b), present in this species.

Remarks. The second pair of muscle scars above those at the base of the mesogastric region (posterior gastric muscle scars) are not confirmed based on the Ernstbrunn material. Unlike the species diagnosis in Starzyk (2013, p. 180) suggests, a pit in the hepatic region seems present in two Ernstbrunn specimens (NHMW 1990/0041/1318, 2014/ 0194/0314). The posterior margin is not often preserved, giving this species a proportionally wider appearance than in reality. Limited intraspecific variation is observed. Unlike for some Mesozoic brachyurans (e.g., Klompmaker et al., 2012), the transverse and longitudinal convexity of smaller specimens is not markedly greater in this species. The augenrest shape is not noticeably different for small vs large specimens, except that larger ones may be somewhat wider proportionally (Figure 16J, $16 \mathrm{~K})$, confirming that overall augenrest shape may be used to distinguish species of different sizes.
Tanidromites sculpta (Quenstedt, 1858)

Figure 17

1858 Prosopon sculptum Quenstedt, p. 778, pl. 95.48.

1858 Prosopon lingulatum von Meyer, p. 61.

1860 Prosopon lingulatum (von Meyer); von Meyer, p. 205, pl. 23.17.

1939 Prosopon wuergauensis Kuhn, p. 492, pl. 15.41.

1988 Pithonoton lingulatum (von Meyer); Wehner, p. 77, pl. 5.6, 5.7 .

2008a Tanidromites lingulata (von Meyer); Schweitzer and Feldmann, p. 140, pl. 6, fig. I-J.

2011 Tanidromites sculpta (Quenstedt); Schweigert and Koppka, p. 229, fig. 7A-B, 7D-E (non fig. 7C).

2013 Tanidromites sculpta (Quenstedt); Starzyk, p. 182, figs. 3,7 .

2016 Tanidromites sculpta (Quenstedt); Starzyk, fig. 2.

Diagnosis. See Starzyk (2013, p. 183).

Material studied. NHMW 1990/0041/0004a, 1990/ 0041/0144, 1990/0041/0689, 1990/0041/3181, $1990 / 0041 / 3985, \quad 1990 / 0041 / 4030, \quad 1990 / 0041 /$ 4196, 1990/0041/4397a, 1990/0041/4561, 1990/ 0041/4677, 1990/0041/4857, 1990/0041/5065, 2014/0194/0313: Late Jurassic (Tithonian) specimens from coral reef limestones of the Ernstbrunn at the Ernstbrunn quarries, Austria (Google Earth coordinates: 48.54, 16.35) (Schweitzer and Feldmann, 2009d; Schneider et al., 2013); I-F/MP/248/ 1495/08: Late Jurassic (Oxfordian) specimen from sponge-microbial limestones at Niegowonice, Poland (Google Earth coordinates: 50.23, 19.26).

Occurrence. Late Jurassic (Oxfordian-Tithonian) of Central Europe (Austria, Germany, and Poland). Dimensions. (In mm) NHMW 1990/0041/0689: max. length excl. rostrum $(L)=>6.3$, max. width $(W)=5.4 ; 1990 / 0041 / 3985: L=\sim 9.4, W=7.4 ; 1990 /$ 0041/4196: $L=9.7, W=7.4 ; 1990 / 0041 / 5065: L=7.5$, $W=5.8 ; 2014 / 0194 / 0313: L=-, W=4.3 ; I-F / M P / 248 /$ 1495/08: L=-, $W=6.3$.

Description. See Starzyk (2013, p. 183). Additional details based on new material: Dorsal carapace moderately vaulted longitudinally and transversely; rostrum triangular, with flared margins and fairly sharp tip. Augenrest flat to slightly concave. Flanks tall, at $\sim 90^{\circ}$ angle from center dorsal carapace surface. Posterior margin rimmed, with pronounced concavity axially. Cuticle and internal mold without ornamentation. Appendages, ventral surface, and abdomen not known.

Remarks. These specimens represent the species Tanidromites sculpta without much doubt because 


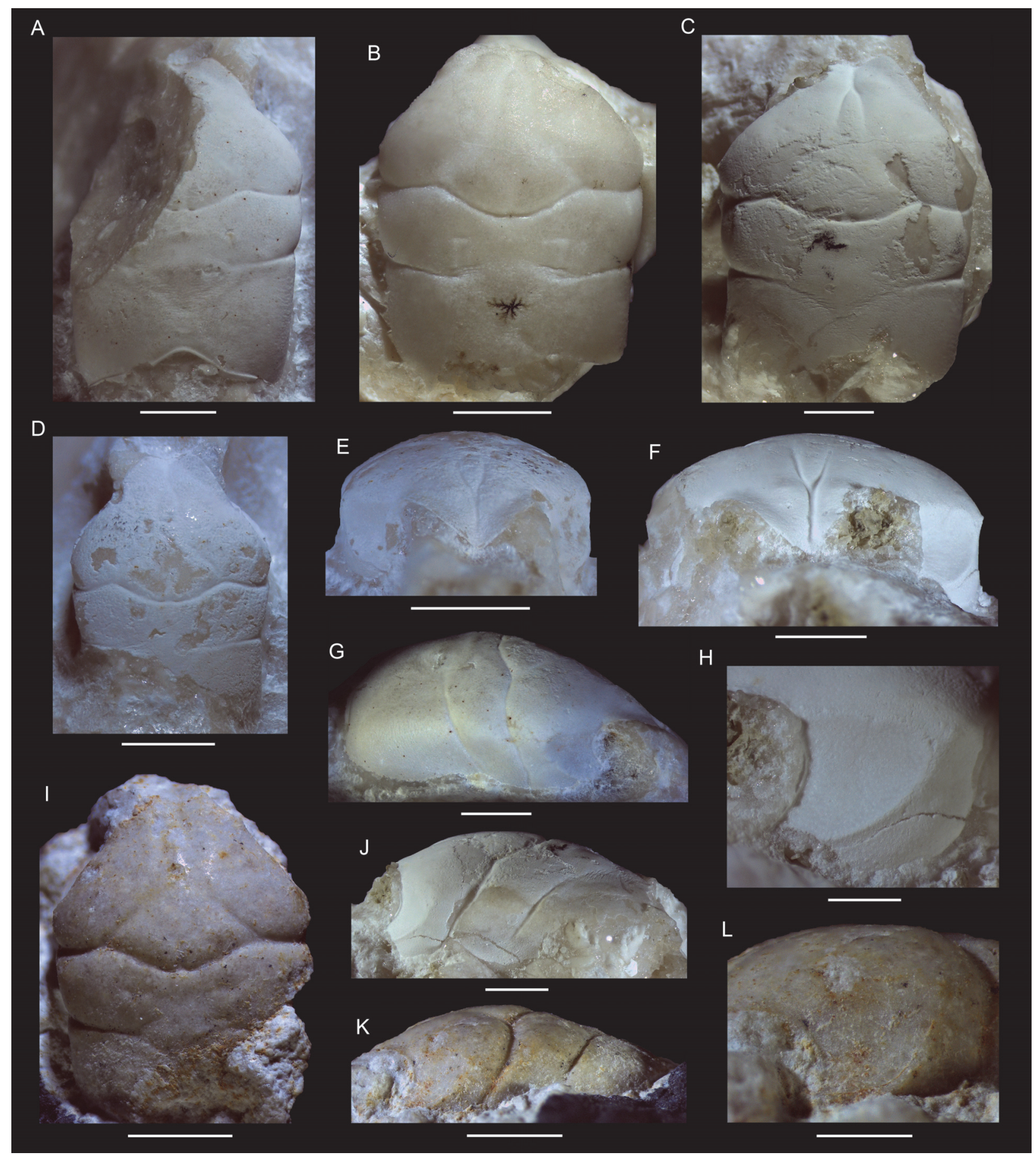

FIGURE 17. Specimens of the crab Tanidromites sculpta (Quenstedt, 1858) from the Late Jurassic (Tithonian) of Ernstbrunn, eastern Austria (all except I, K, L), and the Late Jurassic (middle-late Oxfordian) of Niegowonice, southern Poland (I, K, L) for comparison. A-D, I, dorsal views (NHMW 1990/0041/5065, 1990/0041/0689, 1990/0041/3985, 2014/0194/0313, and I-F/MP/248/1495/08, resp.). E, F, frontal views (NHMW 2014/0194/0313 and 1990/0041/3985, resp.). G, J, K, right- and 2x left-lateral views (NHMW 1990/0041/5065, 1990/0041/3985, and I-F/MP/248/1495/08, resp.). $\mathbf{J}$ and $\mathbf{K}$ are taken at slightly different angles. H, L, straight on views of left orbital structure. (NHMW 1990/0041/ 3985 and I-F/MP/248/1495/08, resp.). Scale bar width is $2.0 \mathrm{~mm}$, except for $\mathbf{H}$ and $\mathbf{L}(1.0 \mathrm{~mm})$. 
they conform well to the holotype (Schweigert and Koppka, 2011, figure 7A, B). The only possible difference between the Tithonian Ernstbrunn specimens versus the Oxfordian (Starzyk, 2013, figure 7; Figure 17I) and Kimmeridgian (Schweigert and Koppka, 2011, figure 7A, B, D, E) specimens is the groove depth that seems shallower in the Tithonian specimens for internal molds for fair comparison (as groove depth is usually shallower when cuticle is preserved). Quenstedt (1858, p. 777-778) did not describe the species in detail (translated from German): "The sculpture is best seen in fig. 48 from Nollhaus, although it may be only an internal mold. The lateral sides are vertical, the groove for the palm [=augenrest] is oriented at a high angle. Since at the same time it has a somewhat different habitat, one might perhaps distinguish it [from Prosopon rostratum] as Prosopon sculptum." The species name most likely refers to the well-defined grooves rather than the ornamentation because the holotype is an internal mold or steinkern and is said not to contain any ornamentation (Schweigert and Koppka, 2011, p. 229). Specimens herein ascribed to T. sculpta do not contain any ornamentation on the cuticle.
The second pair of muscle scars above those at the base of the mesogastric region (Starzyk, 2013 , figures 2, 3) are not confirmed based on the Ernstbrunn material, which applies, too, for the hepatic pits and mesogastric groove tubercles. The posterior margin is not often preserved, giving many specimens a proportionally wider appearance than in reality. Limited intraspecific variation is observed, but the direction of the lateralmost portion of the cervical groove in dorsal view may vary somewhat. The small size range with specimens up to $\sim 10 \mathrm{~mm}$ in length and the lack of very small specimens does not allow to assess possible ontogenetic changes.

\section{Tanidromites weinschenki sp. nov.}

Figure 18

\section{zoobank.org/A85AA221-E934-4F93-BCC8-C1106D489F9D}

2011 Tanidromites sculpta (Quenstedt, 1858); Schweigert and Koppka, p. 229, fig. 7C.

Diagnosis. Species with relatively low length/width ratio, deep grooves, with coarse pustulate ornamentation diminishing in strength posteriorly.

Etymology. After Alwin Weinschenk (Aalen-Wasseralfingen, Germany), who found and donated the specimen.

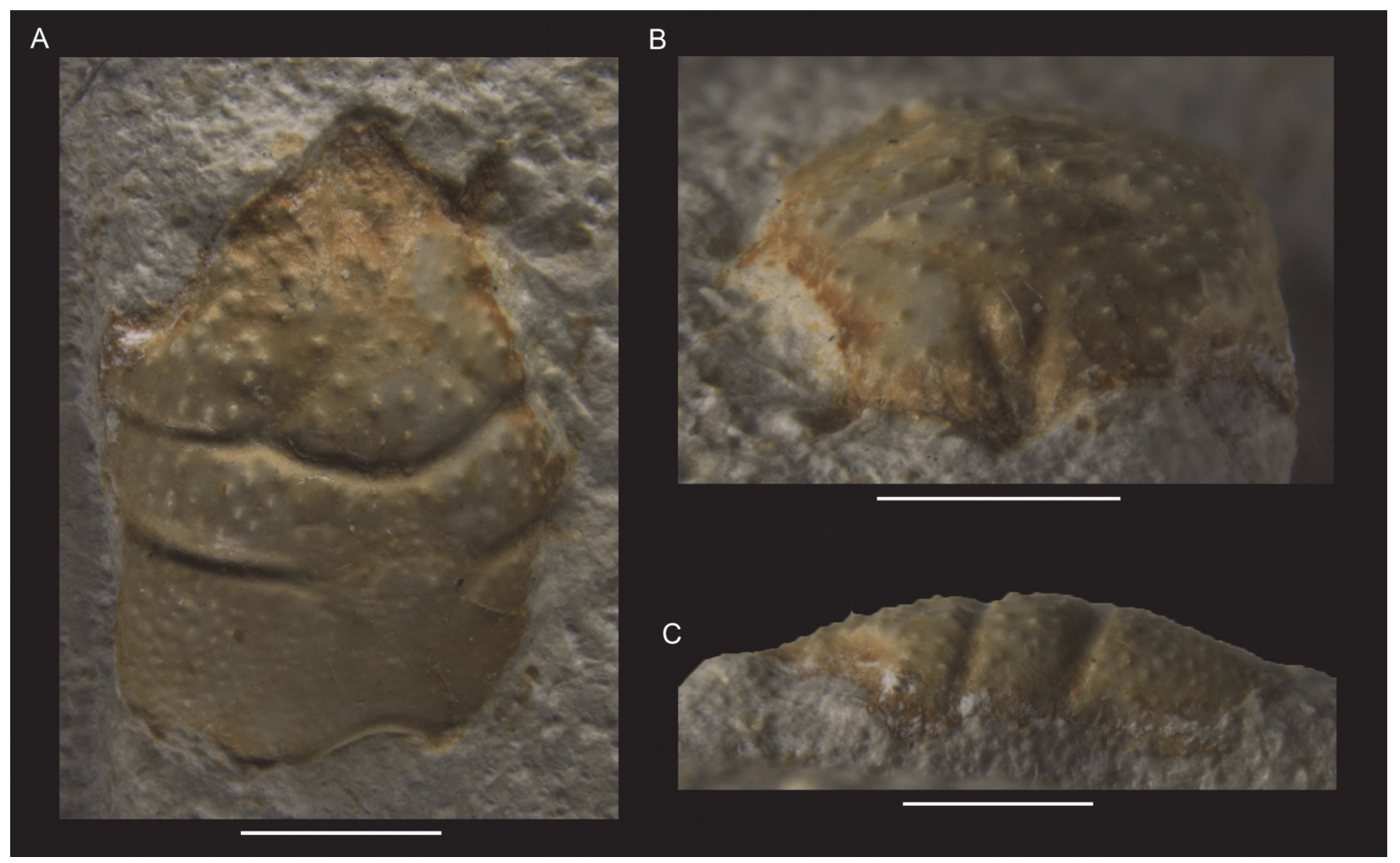

FIGURE 18. Holotype and sole specimen of the crab Tanidromites weinschenki sp. nov. (SMNS 77338) from the Late Jurassic (early Kimmeridgian) of Aalen-Wasseralfingen (Braunenberg quarry area), southwestern Germany. A, dorsal view of carapace. B, frontal view. C, left-lateral view. Scale bar width equals $2.0 \mathrm{~mm}$. 
Material studied. Holotype and sole specimen: SMNS 77338.

Occurrence. Braunenberg quarry area near Aalen-Wasseralfingen, eastern Swabian Alb, Germany (Google Earth coordinates: 48.86, 10.12), calcareous spongiolithic mudstone of the Upper Jurassic Oberjura-Massenkalk Formation, Lochen Member (lower Kimmeridgian, planula Zone, galar Subzone).

Dimensions. (In mm) SMNS 77338: $6.5 \mathrm{~mm}$ long incl. rostrum, $6.0 \mathrm{~mm}$ maximum width.

Description. Carapace outline pentagonal, weakly to moderately convex transversely and longitudinally, slightly longer than wide, with subtriangular anterior part bearing a forwardly directed, incomplete rostrum. Augenrest appears shallow, slightly concave, bordered by dense pustules. True orbits not exposed. Distance between cervical groove and outer orbital edge short $(\sim 1.0 \mathrm{~mm})$. Hepatic and protogastric regions confluent. Mesogastric region triangular to pyriform, appears least marked medially, with narrow anterior process. Uro-/metagastric region narrow, confluent with epibranchial regions. Cardiac region not elevated, posteriorly grading into confluent meso-metabranchial areas. Cervical and branchiocardiac grooves strong, equally deep and well-developed, except near longitudinal axis for latter; both run parallel laterally. Post-cervical grooves short and very shallow. Posterior margin of carapace concave, with smooth rim. Cuticular ornamentation coarser and wider spaced in anterior part of carapace and denser and finer in branchial areas, least prominent on axial part posterior carapace. Appendages, ventral side, abdomen, and ornamentation on internal mold not known.

Remarks. The general outline of Tanidromites weinschenki sp. nov. best resembles T. sculpta. Schweigert and Koppka (2011, figure 7C) referred this specimen with cuticle to $T$. sculpta, but this specimen has many distinct tubercles all over the carapace unlike the smooth internal molds of $T$. sculpta they figured. It is possible for internal molds of brachyurans to show less or no ornamentation than on the cuticular layers (e.g., Klompmaker et al., 2015c), but this is not common. Von Meyer (1860, p. 205) described Prosopon lingulata, now considered to be a junior synonym of $T$. sculpta (Schweigert and Koppka, 2011), based on two specimens that were mentioned to have no ornamentation. Whether these specimens had cuticle preserved is unclear. The specimens of $T$. sculpta from Ernstbrunn do have cuticle preserved in some specimens, but the cuticle does not display any pustules or other ornamentation. Moreover, specimens of the congeneric T. muelleri show both cuticle and the internal mold on the same specimen for multiple specimens (Krobicki and Zatoń, 2016), yielding about equal-sized and spaced tubercles on both surfaces, and the same applies to T. maerteni (Fraaije et al., 2013) and T. montreuilense (Crônier and Boursicot, 2009). Thus, it seems likely that ornamentation or lack thereof is fairly similar on the cuticle versus internals molds for Tanidromites spp. Thus, we use this character to distinguish T. weinschenki sp. nov. from T. sculpta. Tanidromites muelleri also bears ornamentation, but this species has some exceptionally strong tubercles/ spines not seen in $T$. weinschenki sp. nov. and weaker ornamentation on the gastric region. Tanidromites maerteni, T. lithuanicus, T. montreuilense, and $T$. pustulosa appear to have weaker tubercles anterior to the cardiac region. Tanidromites aequilatus, T. alexandrae, T. etalloni, T. hyznyi, $T$. insignis, T. longinosa, T. nightwishorum sp. nov., $T$. raboeufi, T. richardsoni, T. scheffnerae, T. schweitzerae, and T. starzykae all appear to have no or very limited ornamentation. To back up differences in ornamentation between $T$. weinschenki sp. nov. and congenerics, some additional key differences are also given. Tanidromites aequilatus, $T$. alexandrae, and T. hyznyi exhibit deeper augenrests; the carapace of Tanidromites etalloni is more rounded; $T$. insignis, $T$. richardsoni, and $T$. scheffnerae are proportionally longer (e.g., Schweitzer and Feldmann, 2008a, plate 6; Schweigert and Koppka, 2011, figures 5, 6, 8; Hyžný et al., 2011, figure 2A; Starzyk, 2013, figures 4, 6; Figure 18); the cardiac region of $T$. lithuanicus is outlined more pronounced than in $T$. weinschenki sp. nov.; T. nightwishorum sp. nov. has much more swollen epibranchial regions; $T$. longinosa and $T$. raboeufi have a proportionally longer gastric region; $T$. maerteni bears at least two tubercles on the lateral margin, not seen in the new species; $T$. montreuilense widens more posteriorly; the postcervical grooves are deeper in T. muelleri; the rostrum of T. pustulosa is less prominent in dorsal view (Schweitzer and Feldmann, 2010c, figure 1.13-1.14; Hyžný and Zorn, 2016, plate 2.4-2.5, incorrectly referred to Eodromites rostratus); the cervical groove of $T$. schweitzerae is oriented more obliquely on the flank; the curve in the cervical groove at the position of the posterior edges of the mesogastric region is more pronounced in $T$. sculpta; and the grooves of $T$. starzykae are less prominent and largely lacking for the mesogastric region. 


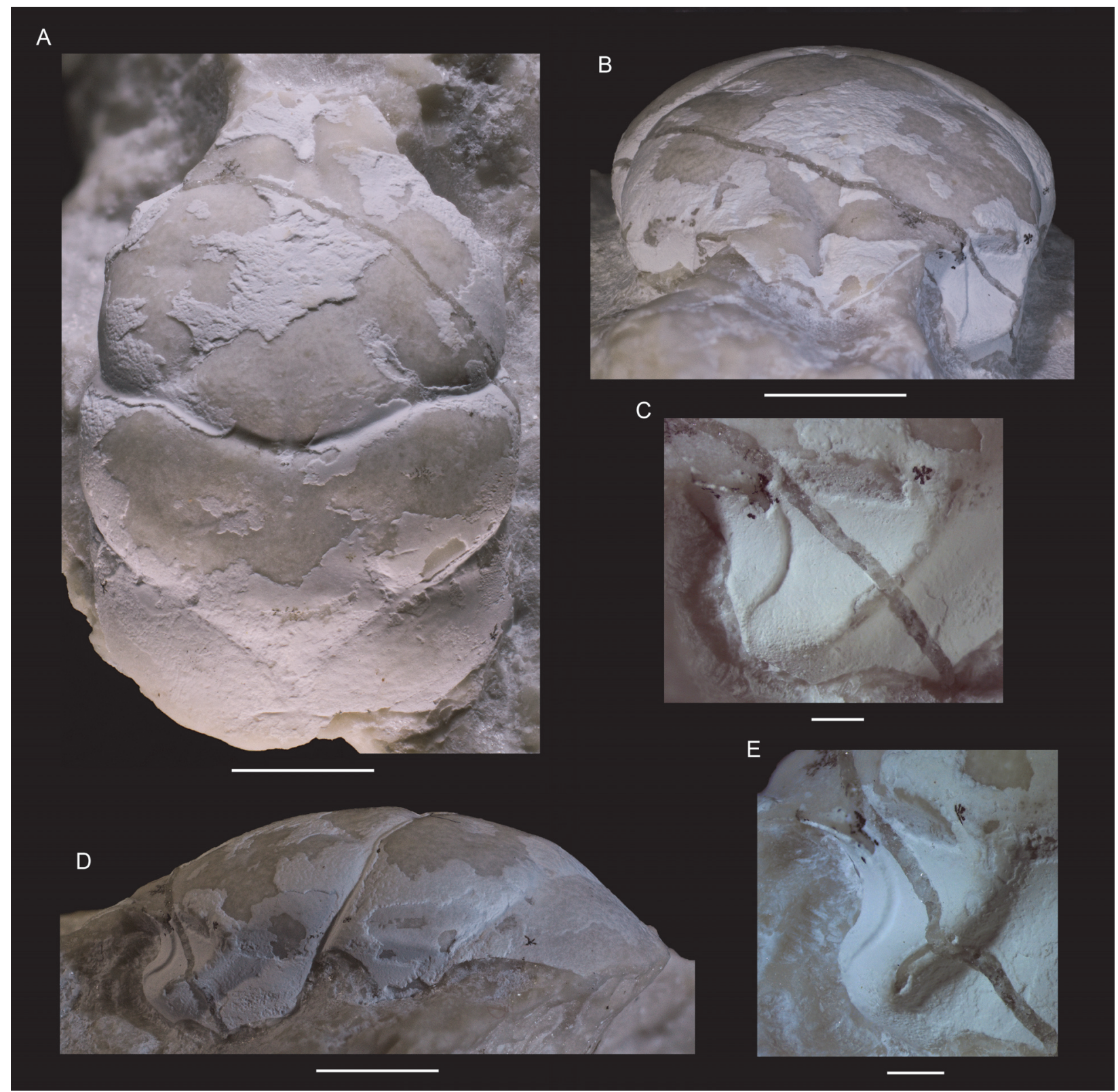

FIGURE 19. Holotype and sole specimen of the crab Tanidromites nightwishorum sp. nov. (NHMW 1990/0041/3327) from the Late Jurassic (Tithonian) of Ernstbrunn, eastern Austria. A, dorsal view of carapace. B, frontal view. C, orbital view (straight on). D, left-lateral view. E, orbital view (laterally). Scale bar width is $5.0 \mathrm{~mm}$, except for $\mathbf{C}$ and $\mathbf{E}$ (1.0 $\mathrm{mm})$.

\section{Tanidromites nightwishorum sp. nov. \\ Figure 19}

\section{zoobank.org/E467C990-505E-4047-9DFA-1EF726781C6D}

Diagnosis. Carapace rectangular, length-width ratio $>1.4$, widest at very swollen epibranchial region. Rostrum with wide base, slightly downturned. Augenrest moderately concave, semicircular, taller than wide, with short groove isolating outer orbital angle; lower orbital margin extending beyond upper orbital margin, which contains some tubercles or spines. Lateral margin rounded; flanks with depression posterior to orbital rim. Cuticle and internal mold bear limited ornamentation as preserved, some small tubercles on hepatic region.

Etymology. Named in honor of the members of the symphonic metal band Nightwish (Troy Donockley, Kai Haito, Marco Hietala, Tuomas Holopainen, Floor Jansen, and Emppu Vuorinen), in particular for their 2015 album "Endless Forms Most Beautiful" about the evolution of life. 
Material studied. Holotype and sole specimen: NHMW 1990/0041/3327.

Occurrence. Coral reef Ernstbrunn Limestone of the Ernstbrunn quarries (Google Earth coordinates: 48.54, 16.35), Austria, Late Jurassic (Tithonian) (Schweitzer and Feldmann, 2009d; Schneider et al., 2013).

Dimensions. (In mm) NHMW 1990/0041/3327: max. length excl. rostrum $(L)=>21.6$, max. width $(\mathrm{W})=15.5$.

Description. Carapace rectangular, length-width ratio $>1.4$, holotype large for genus, widest at epibranchial region, moderately convex longitudinally and transversely. Rostrum with wide base, with axial groove, slightly downturned. Orbital structure anterolaterally oriented, augenrest moderately concave, semicircular, taller than wide, with short groove isolating outer orbital angle; lower orbital margin extending beyond upper orbital margin, which contains some tubercles or spines. Epigastric regions distinctly swollen. Protogastric and hepatic regions confluent but with shallow groove arising from upper orbital margin to hepatic pit; with circular group of hepatic pits on internal mold (antennar extensor muscle scars), anterior to hepatic pit. Mesogastric region pyriform, with pair of semicircular muscle scars (posterior gastric muscles) at base on internal mold. Uro-metabranchial region short, confluent laterally with epibranchial regions, which are long and swollen laterally. Cardiac region subpentagonal, fairly large, poorly delimited anteriorly. Meso-metabranchial region not divided, depressed, incompletely preserved. Intestinal region not well-visible. Lateral margin rounded, not rimmed; flanks steep, with depression posterior to orbital rim. Mesogastric groove weaker in middle part, with tubercle in posterior part. Cervical groove strong, widely U-shaped in center, then curving more laterally at intersection with mesogastric groove, then bending forward again on flank, with gastric pits just adjacent to longitudinal axis. Postcervical grooves shallow, consisting of two short grooves, not expressed at axial region. Branchiocardiac groove strong laterally, less pronounced at axial region, bending forward on flank. Cuticle and internal mold bear limited ornamentation as preserved, some small tubercles on hepatic region. Posterior margin, appendages, venter, and abdomen not preserved.

Remarks. Superficially, this specimen most resembles Tanidromites insignis, $T$. aequilatus, and $T$. alexandrae. Though reminiscent of $T$. insignis in overall shape, size, groove structure, and convexity, the lower orbital margin is protruding much more than in T. insignis, and the course of the cervical groove appears more forwardly oriented on the flank than in T. insignis (Wehner, 1988, plate 5.2b; Schweitzer and Feldmann, 2008a, figure 6D; Schweigert and Koppka, 2011, figure 6C; Starzyk, 2013, figure 4E, G; herein). Additionally, this specimen contains a number of pits arranged in a circle just anterolaterally to the hepatic pit on the internal mold, not seen in a well-preserved, studied specimen of $T$. insignis from the Oxfordian of Poland (IF/MP/6253/1588/11) or any other figured specimens of $T$. insignis, although the quality of the figures is often insufficient to be sure, so more specimens are needed to confirm this difference. This circle is equivalent to the "hepatic pits", representing antennar extensor muscle attachment scars (Klompmaker et al., 2019), also seen in Eodromites spp. (Starzyk, 2015b). The grooves of the Polish specimen of $T$. insignis mentioned above are shallower.

Multiple differences exist compared to $T$. aequilatus. The meso-metabranchial regions of the new species appear much more depressed, and the epibranchial regions are more swollen than in T. aequilatus (Wehner, 1988, plate 5.4, 5.5; Schweitzer and Feldmann, 2008a, plate 3E; Starzyk, $2015 b$, figure 5). Furthermore, the rostrum may be more downturned in $T$. aequilatus, the orbital structure is oriented more anterolaterally in dorsal view, and the augenrest seems rimmed more strongly.

Tanidromites alexandrae is similar in many aspects, including the extended lower orbital margin and the shape of this margin, the presence of mesogastric groove tubercles, the single hepatic pit, a posterior groove originating from the upper orbital margin (sensu Starzyk, 2015a), and the overall pattern and strength of the grooves. As in $T$. alexandrae, there also appear to be small spines/ tubercles on the upper orbital margin. However, the augenrests appear wider relative to the height in $T$. alexandrae (Starzyk, 2015a, figure 2F, 2G; Figure 19). Another difference is the presence of a groove within the lateralmost part of the augenrest intersecting with the upper orbital margin but not with the lower orbital margin, a feature not present in $T$. alexandrae (e.g., Starzyk, 2015a, figure 2; UF 272110; UF 272116). Furthermore, the ratio of the length from the outer orbital angle to the cervical groove at the lateral margin divided by the estimated length from the tip of the rostrum to the cervical groove on the axis is $\sim 0.33$ for the new species, whereas this ratio ranges from $0.21-0.26$ for T. alexandrae (Starzyk, 2015a). It may be possible that this ratio increases as the animal grows 
because a single relatively large specimen of the type series of $T$. wysokaensis (=junior synonym of $T$. scheffnerae) has the highest ratio (0.41), but a larger specimen of $T$. scheffnerae from the same region and stratigraphic level (I-F/MP/6261/1588/ 11 ) has a ratio of only 0.34 . Another possible difference is the maximum size: out of 211 specimens, the maximum length of $T$. alexandrae is only 9.6 $\mathrm{mm}$, whereas the single specimen under study is > $21.6 \mathrm{~mm}$ long excluding the rostrum. Finally, the cervical groove is directed more forward in this specimen compared to $T$. alexandrae (Starzyk, 2015a, figure 2B).

Nearly all other congenerics bear less swollen epibranchial regions, except perhaps for Tanidromites lithuanicus and T. schweitzerae. Furthermore, T. etalloni, a species with a smaller maximum size, shows a cervical groove that is more vertically oriented on the flank in lateral view (pers. obs. AAK of I-F/MP/6254/1588/11 and I-F/MP/1740/1517/08), and the lower orbital margin seems less prominent. The small specimens of $T$. hyznyi have a proportionally shorter distance of the lateral margin anterior to the intersection of the cervical groove, and they possess proportionally wider augenrests. Tanidromites lithuanicus has a more downturned rostrum, more ornamentation on the cuticle, and a more swollen cardiac region. The orbital margins of $T$. longinosa are less prominent so that the augenrests appear shallower. Unlike the new species, T. maerteni bears two strong tubercles/spines on the lateral margin. The meso-metabranchial region of $T$. montreuilense seems proportionally larger, and its rostrum is more downturned. Tanidromites pustulosa (Schweitzer and Feldmann, 2010c, figure 1.13-1.14; Hyžný and Zorn, 2016, plate 2.4) bears many tubercles across the carapace (rare in the new species as preserved) and has a narrower base of the rostrum. Tanidromites raboeufi and $T$. scheffnerae bear less concave augenrests. Tanidromites richardsoni exhibits larger outer orbital projections. Specimens of $T$. sculpta, much smaller in maximum size in the same Ernstbrunn assemblage based on 12 specimens, have a proportionally shorter distance of the lateral margin anterior to the intersection of the cervical groove, which applies too to T. muelleri and $T$. weinschenki sp. nov. The latter two species are also more tubercular. The comparably-sized holotype of $T$. schweitzerae ( $14.8 \mathrm{~mm}$ wide) has no tubercles/spines on the upper orbital margin, bears lower orbital margins that are projected more forwardly, and the rostrum's base is narrower. The small specimen of Tanidromites starzykae contains grooves that are oriented more transversely than in the new species.

Superfamily KONIDROMITOIDEA Schweitzer and Feldmann, 2010a

Family KONIDROMITIDAE Schweitzer and Feldmann, 2010a

Genus KONIDROMITES Schweitzer and Feldmann, 2010a

Type species. Oxythyreus gibbus Reuss, 1858, by original designation.

Included species. Konidromites gibbus (Reuss, 1858); ?K. schneideri (Stolley, 1924).

Konidromites gibbus (Reuss, 1858)

Figure 20

1858 Oxythyreus gibbus Reuss, p. 12.

1859 Oxythyreus gibbus Reuss; Reuss, p. 75, pls 23.6, 24.8.

1869 Oxythyreus gibbus Reuss; Gemmellaro, p. 18.

1895 Oxythyreus gibbus Reuss; Remeš, p. 6, pl. 1.5.

1895 Oxythyreus minor Remeš, p. 6, pl. 1.6.

1929 Oxythyreus gibbus Reuss; Lőrenthey and Beurlen, p. 96, pl. 4.3.

1969 Oxythyreus gibbus Reuss; Glaessner, R489, fig. 301.2.

2006 Oxythyreus gibbus Reuss; Shirk, p. 95, fig. 26.

2010a Konidromites gibbus (Reuss); Schweitzer and Feldmann, p. 365, fig. 1.

2012b Konidromites gibbus (Reuss); Schweitzer et al., p. 20, fig. 12.1.

2016 Konidromites gibbus (Reuss); Hyžný and Zorn, p. 129 , pl. 1.4, 1.5a-d.

2018 Konidromites gibbus (Reuss); Schweitzer et al., p. 331 , fig. 15.

Diagnosis. See Schweitzer and Feldmann (2010, p. 364).

Material studied. NHMW 1990/0041/5082, 1990/ 0041/5104, 2014/0194/0669: Late Jurassic (Tithonian) specimens from the coral reef Ernstbrunn Limestone of the Ernstbrunn quarries (Google Earth coordinates: 48.54, 16.35), Austria (Schweitzer and Feldmann, 2009d; Schneider et al., 2013).

Occurrence. Late Jurassic (Tithonian) of Europe (Austria, Czech Republic, Italy, and Romania).

Dimensions. (In mm) NHMW 1990/0041/5082: max. length excl. rostrum $(L)=12.5$, max. width excl. projections $(W)=10.0 ; \quad 1990 / 0041 / 5104$ : $L=6.0, \quad W=4.8 ; \quad 2014 / 0194 / 0669: \quad L=2.4, \quad W=1.8$; 1990/0041/3475: $L=12.2, W=10.0$.

Description. Referral is made to Schweitzer and Feldmann (2010a, 366-367). Additionally: small and a larger specimen with fairly continuous orbital rim with indent laterally. Orbital cavity narrow. Ros- 


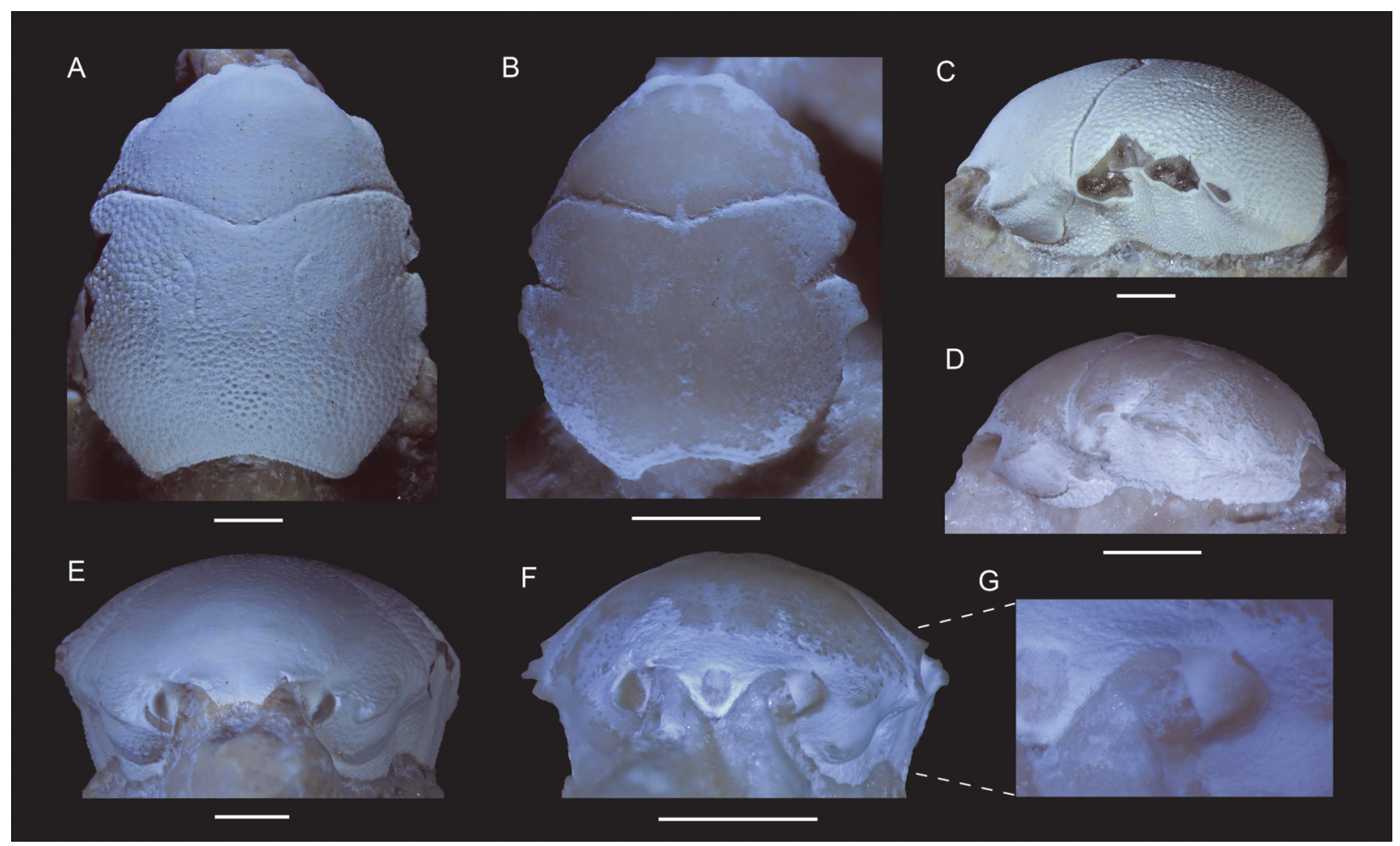

FIGURE 20. A large and small specimen of the crab Konidromites gibbus (Reuss, 1858) from the Late Jurassic (Tithonian) of Ernstbrunn, eastern Austria. A, C, E, dorsal, left-lateral, and frontal views, resp. (NHMW 2014/0194/0669). B, D, F, G, dorsal, left-lateral, frontal, and left-orbital views (NHMW 1990/0041/5104). Scale bar width equals $2.0 \mathrm{~mm}$.

trum downturned and triangular, reaches height of lower orbital rim in frontal view, with median groove. For larger specimens, fronto-orbital width relative to maximum width relatively small $(0.49 \mathrm{vs}$ 0.56 ) and less convex transversely (Figure 20).

Remarks. This species has been figured many times (see synonymy list), but frontal and orbital views have never been provided thus far. Ontogenetic change appears limited, with only the transverse convexity of the dorsal carapace being a bit more pronounced in the small relative to the large specimen.

\section{DISCUSSION}

\section{Paleobiogeography}

All studied specimens originate from coraland sponge-associated environments in Europe, primarily from the Late Jurassic. During this epoch, a shallow, tropical ocean covered many parts of Europe linked to a high sea level (Leinfelder et al., 2002, figure 4). Decapod crustaceans, such as anomurans (Robins et al., 2013, 2016; Fraaije, 2014; Robins and Klompmaker, 2019; Fraaije et al., 2020), but particularly brachyurans, diversified rapidly in these environments in Central Europe
(Müller et al., 2000; Krobicki and Zatoń, 2008; Klompmaker et al., 2013b), whereas species richness of these decapods was much lower in Upper Jurassic Konservat-Lagerstätten in the same region (e.g., Audo et al., 2014; Feldmann et al., 2016). The Late Jurassic taxa described herein reinforce the hypothesis that the Late Jurassic and Europe were an important epoch and continent in the evolutionary history of brachyurans.

During the Cretaceous, brachyurans were living in a variety of environments in Europe and not primarily in reef environments (e.g., Wright and Collins, 1972; Collins et al., 1995; Breton and Collins, 2011; Klompmaker, 2013a; Robin et al., 2019). This environmental differentiation may have played a key role in their recovery and diversification during the Cretaceous after a loss of diversity in the earliest Cretaceous (Klompmaker et al., 2013b; Schweitzer and Feldmann, 2015).

\section{Biostratigraphic Implications}

Two species represent the stratigraphically youngest occurrences of their respective genera. Eodromites cristinarobinsae sp. nov. is mid-Cretaceous (late Albian) in age, whereas the next youngest member of Eodromites originates from 
the Early Cretaceous (Berriasian-Hauterivian) (Klompmaker et al., 2012, table 1; Starzyk, 2015b, table 1). The confirmed range of Eodromites is from the Late Jurassic (Oxfordian) to the mid-Cretaceous (late Albian) (Klompmaker et al., 2012, table 1; Starzyk, 2015b, table 1). Tanidromites ranges from the Middle Jurassic (Bajocian) to the Late Jurassic (Tithonian) (see also Starzyk, 2016, table 2), with $T$. pustulosa as the youngest representative. The three species of Tanidromites described here from the Tithonian of Ernstbrunn thus share the youngest record of the genus.

\section{Paleoecology}

The mean carapace size of brachyurans has increased throughout the Mesozoic, which was particularly attributed to the appearance and diversification of several clades of Raninoida (Klompmaker et al., 2015a) in siliciclastic environments. Likewise, the maximum carapace size of brachyurans increased as well. Here we report on the largest complete carapace of a crab from the Jurassic: a coral-associated specimen of Abyssophthalmus cf. $A$. spinosus with a maximum length excluding rostrum of $39.1 \mathrm{~mm}$ and a maximum width excluding spines of $30.1 \mathrm{~mm}$. The largest complete crab carapace from the Jurassic reported was from Prosopon mammillatum $(37.6 \mathrm{~mm}$ long, $27 \mathrm{~mm}$ wide) (Klompmaker et al., 2015a, database), although larger incomplete specimens up to $\sim 55$ $\mathrm{mm}$ in length are known from oolitic limestones (Withers, 1951). These large Jurassic specimens do not change the increase in maximum size from the Jurassic to the Cretaceous because the largest Cretaceous crab carapaces known to us are substantially larger [Megaxantho zoque Vega et al., 2001, Maastrichtian, calcarenite/marl: $109.4 \mathrm{~mm}$ long, $126.7 \mathrm{~mm}$ wide; Ophthalmoplax brasiliana (Maury, 1930): $120 \mathrm{~mm}$ long, $140 \mathrm{~mm}$ wide (Vega et al., 2013, Maastrichtian, limestone)]. On average, crabs tend to be relatively small in Mesozoic reef environments (Klompmaker et al., 2015a), as they are in Modern reefs (Abele, 1976). The specimen of Abyssophthalmus cf. A. spinosus is one of the largest crabs known from a Mesozoic coralassociated environment. From the Cretaceous, a large specimen of Cenomanocarcinus cantabricus Van Bakel et al., 2012 (33.3 mm long, $43.3 \mathrm{~mm}$ wide), was found in a coral-associated habitat (Baron-Szabo and Fernández-Mendiola, 1997), which is much smaller than the two Cretaceous crabs mentioned above from different habitats.

One of the specimens of Planoprosopon aff. $P$. hystricosus contains a swelling in the right gill chamber (Figure 9C, E), most likely caused by a parasitic epicaridean isopod, referred to the ichnotaxon Kanthyloma crusta Klompmaker et al., 2014. While these soft-bodied isopods themselves have a low preservation potential as shown experimentally (Klompmaker et al., 2017) and only some fossil larvae are known (Serrano-Sánchez et al., 2016; Néraudeau et al., 2017; Schädel et al., 2019), the swellings they leave behind in the host cuticle are known from the Jurassic onwards (e.g., Wienberg Rasmussen et al., 2008; Klompmaker et al., 2014; Klompmaker and Boxshall, 2015). Such swellings have been reported from the Ernstbrunn fauna from multiple decapod taxa (Schweitzer and Feldmann, 2009c; Robins et al., 2013, 2016; Robins and Klompmaker, 2019), but this specimen bears one of the largest swellings relative to the carapace size in their entire fossil record. The carapace is $14 \%$ wider and $6 \%$ longer than is normal, but the swelling is also remarkably tall [compare to specimens in Rasmussen Wienberg et al. (2008) and Klompmaker et al. (2014)]. This size of the parasite relative to the host indicates long-term survival of the host.

\section{Convergent Evolution in Brachyurans}

While convergence has been recognized in crustaceans (see also introduction), the commonness of convergence in brachyurans remains understudied, in particular for their fossil record. A full assessment is hampered by the fact that brachyurans are often incompletely preserved with just the carapace available (Guinot, 2019) and the lack of modern representatives for various clades that originated in the Mesozoic. The discovery of venters associated with early brachyuran carapaces would help tremendously to assess convergent evolution more thoroughly. Without venters, features of the orbital region and carapace flanks may aid those of dorsal carapaces in testing hypotheses about relatedness and convergence. It is clear from modern decapods that appendages can be highly influenced by life mode and appear less informative about relatedness than a combination of dorsal and ventral characters.

Some examples of convergence are recognized for Mesozoic taxa, such as the flattened, wider than long carapace shape for presumed swimming crabs. A reassessment of all members included at some point within Etyidae resulted in the ascription of some species to distantly related families and superfamilies (Schweitzer et al., 2012a). A burrowing mode of life may also contribute to similar-shaped carapaces (Corystidae vs 
Palaeocorystes and Eucorystes) (see introduction, Bell, 1863). The Cretaceous crab Rathbunopon, a member of Glaessneropsoidea according to Karasawa et al. (2011) and Schweitzer et al. (2018), was implied by them to represent one the most extreme examples of convergent evolution in the crustacean fossil record. This taxon closely resembles Europrosopon (Homolodromioidea) for nearly all carapace regions, except for a part of the orbital structure (Figure 10). Our re-examination of Rathbunopon suggests that this taxon is closely related to Europrosopon, rejecting extreme convergent evolution.

Whereas the overall carapace shape may appear similar in distantly related taxa due to convergence, certain parts of the carapace are also prone to convergence. Here we showed that the frontal region with diverging rostral spines and anterolateral spines is an example of convergent evolution in the goniodromitid Navarradromites pedroartali because such a frontal structure is typical for members of Homolodromiidae, but not for Goniodromitidae. On the other hand, a similar rostrum and outer orbital spines in Nodoprosopon led us to place this genus in Homolodromiidae, while also taking into account other characters. Thus, the rostrum and outer orbital spines do not represent convergent evolution in this case. Rostral spines can be an example of convergent evolution because they are found among members of some Homolidae De Haan, 1839, Homolodromiidae, Priscinachidae, Poupiniidae, and some Raninoida.

\section{CONCLUSIONS}

1. The term "mesogastric groove tubercles" is proposed to replace "hepatic tubercles" for tubercles found within the groove delimiting the lateral margin of the mesogastric region.

2. Six new taxa are erected: the Late Jurassic (Kimmeridgian-Tithonian) prosopid Europrosopon gen. nov., the Late Jurassic (Oxfordian) goniodromitid Eodromites bernchrisdomiorum sp. nov., mid-Cretaceous (late Albian) Eodromites cristinarobinsae sp. nov., the Late Jurassic (Tithonian) prosopid Prosopon josephcollinsi sp. nov., the Late Jurassic (Tithonian) tanidromitid Tanidromites nightwishorum sp. nov., and the Late Jurassic (early Kimmeridgian) tanidromitid $T$. weinschenki sp. nov. Eodromites cristinarobinsae is the stratigraphically youngest record of Eodromites to date, whereas T. nightwishorum and $T$. weinschenki are among the youngest examples of Tanidromites.
3. We recognize four new junior synonyms: Eodromites grandis (=E. guenteri), Tanidromites scheffnerae ( $=T$. wysokaensis), and Europrosopon aculeatum comb. nov. (=E. verrucosum and $E$. barbulescuae). We reinstate Nodoprosopon circinatum as a junior synonym of $N$. ornatum.

4. Five taxa are reassigned: Eodromites aequilatus to Tanidromites, Tanidromites rotundus to Eodromites, Nodoprosopon dzhafarberdensis to ?Abyssophthalmus, Nodoprosopon from Nodoprosopidae to Homolodromiidae, and Rathbunopon from Glaessneropsidae to Prosopidae.

5. Several existing taxa are redescribed and/or refigured from angles not photographed previously: Abyssophthalmus cf. A. spinosus, Konidromites gibbus, Laeviprosopon punctatum, Tanidromites scheffnerae, T. sculpta, Nodoprosopon ornatum, Protuberosa protuberosa, and Planoprosopon aff. P. hystricosus.

6. Abyssophthalmus cf. A. spinosus from the Tithonian of Ernstbrunn, eastern Austria, represents the largest complete reported brachyuran carapace from the Jurassic thus far, and one of the largest crabs known from a Mesozoic coral-associated habitat.

7. One specimen of Planoprosopon aff. P. hystricosus bears one of the largest parasitic isopod-induced swellings relative to carapace size in the fossil record (ichnotaxon Kanthyloma crusta).

8. The frontal structure with a bifid rostrum and anterolaterally oriented spines is a remarkable example of convergent evolution of the goniodromitid crab Navarradromites toward members of Homolodromiidae, for which this frontal structure is characteristic. Conversely, our reassignment of Nodoprosopon from Nodoprosopidae to Homolodromiidae implies that the trifid rostrum and outer orbital spines in Nodoprosopon do not represent an example of convergence. Rostral spines do represent an example of convergent evolution occasionally because they can be found among distantly related taxa such as the homolid Doerflesia, Priscinachidae, Poupiniidae, and some Raninoida, some Prosopidae, and Bucculentidae.

9. Our reassignment of Rathbunopon from Glaessneropsidae to Prosopidae based upon close similarities with Europrosopon spp. 
implies that Rathbunopon does not represent an example of extreme convergent evolution.

\section{ACKNOWLEDGMENTS}

We thank A. Kroh, T. Nichterl, and A. Krapf (all Naturhistorisches Museum Wien, Vienna, Austria) for much appreciated help with handling loans and for facilitating a productive research stay in Vienna in 2017. C. Robins (then Museum of Paleontology at the University of California Berkeley, California, USA, now Department of Museum Research and Collections, University of Alabama) accompanied AAK in Vienna and helped sorting decapods. We are grateful to E. Mychko (Russian Academy of Sciences, Moscow, Russia) and A. Alekseev (Lomonosov Moscow State University, Moscow, Russia) for providing a higher resolution image of
Nodoprosopon dzhafarberdensis. R. Feldmann (Kent State University, Ohio, USA) provided some images of Eodromites grandis for comparison. C. D'Arpa (Museo Geologico G.G. Gemmellaro, Palermo, Italy) facilitated the use of figures of the specimen of Eodromites polyphemi photographed by S. Rubino. The University of California Museum of Paleontology provided equipment for photos. We very much thank the four reviewers (À. Ossó; N. Robin, University College Cork, Cork, Ireland; and two anonymous reviewers) and handling editor M. Hyžný (Comenius University, Bratislava, Slovakia) for providing helpful comments. This research was supported by a Paleontological Society A.J. Boucot research grant to AAK to visit the NHM Vienna to study evidence of parasitism.

\section{REFERENCES}

Abele, L.G. 1976. Comparative species composition and relative abundance of decapod crustaceans in marine habitats of Panama. Marine Biology, 38:263-278.

Alcock, A. 1896. Material for a carcinological fauna of India, No. 2. The Brachyura Oxystomata. Journal of the Asiatic Society of Bengal, 65:134-296.

Alcock, A. 1900. Materials for a carcinological fauna of India, No. 5. The Brachyura Primigenia or Dromiacea. Journal of the Asiatic Society of Bengal, 68:123-169.

An, J., Boyko, C.B., and Li, X. 2015. A review of bopyrids (Crustacea: Isopoda: Bopyridae) parasitic on caridean shrimps (Crustacea: Decapoda: Caridea) from China. Bulletin of the American Museum of Natural History, 399:1-85. https://doi.org/10.1206/amnb-921-00-01.1

Audo, D., Charbonnier, S., Schweigert, G., and Martin, J.-P.S. 2014. New eryonid crustaceans from the Late Jurassic Lagerstätten of Cerin (France), Canjuers (France), Wattendorf (Germany) and Zandt (Germany). Journal of Systematic Palaeontology, 12:459-479. https:// doi.org/10.1080/14772019.2013.777809

Bachmayer, F. 1964. Ein Korallenriff in Niederösterreich. Schätze im Boden. Bilder aus Österreichs geologischer Vergangenheit. Veröffentlichungen aus dem Naturhistorischen Museum, Neue Folge 5:102-111.

Báez, R.P. and Martin, J.W. 1989. Crabs of the family Homolodromiidae, I. Description of the male Homolodromia robertsi Garth, 1973, based on specimens from deep waters off the coast of Chile. Journal of Crustacean Biology, 9:492-500. https://doi.org/10.1163/ $193724089 \times 00476$

Barnes, R.S.K. 1968. Relative carapace and chela proportions in some ocypodid crabs (Brachyura, Ocypodidae). Crustaceana, 14:131-136.

Baron-Szabo, R.C. and Fernández-Mendiola, P.A. 1997. Cretaceous scleractinian corals from the Albian of Cabo de Ajo (Cantabria Province, N-Spain). Paläontologische Zeitschrift, 71:3550. https://doi.org/10.1007/BF03022545

Bell, T. 1863. A Monograph of the Fossil Malacostracous Crustacea of Great Britain, Pt. II, Crustacea of the Gault and Greensand. Palaeontographical Society Monograph, London.

Beurlen, K. 1928a. Die Decapoden des schwäbischen Jura mit Ausnahme der aus den oberjurassischen Plattenkalken stammenden. Palaeontographica, 70:115-278, pls. 6-8.

Beurlen, K. 1928b. Die fossilen Dromiaceen und ihre Stammesgeschichte. Paläontologische Zeitschrift, 10:144-183. https://doi.org/10.1007/BF03041570

Beurlen, K. 1932. Brachyurenreste aus dem Lias von Bornholm mit Beiträgen zur Phylogenie und Systematik der brachyuren Dekapoden. Paläontologische Zeitschrift, 14:52-66. https:// doi.org/10.1007/BF03041617 
Bishop, G.A. 1976. Ekalakia lamberti n. gen., n. sp. (Crustacea: Decapoda) from the Upper Cretaceous Pierre Shale of eastern Montana. Journal of Paleontology, 50:398-401.

Bishop, G.A. 1986. Occurrence, preservation, and biogeography of the Cretaceous crabs of North America, p. 111-142. In Gore, R.H. and Heck, K.L. (eds.), Crustacean Issues 4: Crustacean Biogeography. Balkema Press, Rotterdam.

Blow, W.C. 2003. New brachyuran crabs (Crustacea: Decapoda) from the Upper Pliocene Yorktown Formation of southeastern Virginia. Proceedings of the Biological Society of Washington, 116:168-189.

Breinholt, J.W., Porter, M.L., and Crandall, K.A. 2012. Testing phylogenetic hypotheses of the subgenera of the freshwater crayfish genus Cambarus (Decapoda: Cambaridae). PLoS ONE, 7:e46105. https://doi.org/10.1371/journal.pone.0046105

Breton, G. 2009. Description of Priscinachus elongatus n. gen., n. sp., and Priscinachidae n. fam. for the earliest spider crab (Crustacea, Decapoda, Majoidea), from the French Cretaceous (Cenomanian). Geodiversitas, 31:509-523. https://doi.org/10.5252/g2009n3a2

Breton, G. and Collins, J.S.H. 2011. New and rare Cenomanian crabs (Crustacea, Decapoda, Brachyura) from the Paris Basin (France), and a comparison with necrocarcinids, etyids and dynomenids from Devon (England). Neues Jahrbuch für Geologie und PaläontologieAbhandlungen, 260:141-156. https://doi.org/10.1127/0077-7749/2011/0166

Checchia-Rispoli, G. 1917. Distefania, nuovo genere di Brachiuri del Cenomaniano della Sicilia. Bollettino della Società Zoologica Italiana, 3:173-186, pls. 1-2.

Collins, J.S.H. 2002. A taxonomic review of British decapod Crustacea. Bulletin of the Mizunami Fossil Museum, 29:81-92.

Collins, J.S.H. and Wierzbowski, A. 1985. Crabs from the Oxfordian sponge megafacies of Poland. Acta Geologica Polonica, 35:73-88.

Collins, J.S.H., Fraaye, R.H.B., and Jagt, J.W.M. 1995. Late Cretaceous anomurans and brachyurans from the Maastrichtian type area. Acta Palaeontologica Polonica, 40:165-210.

Collins, J.S.H., Ross, A.J., Genzano, G., and Mianzan, H. 2006. Earleria gen. nov. \& Gabriella gen. nov., replacement names for Foersteria Arai \& Brinckmann-Voss, 1980 (Cnidaria, Hydrozoa, Mitrocomidae) and Foersteria Wehner, 1988 (Crustacea, Decapoda, Prosopidae), junior homonyms of Foersteria Szépligeti, 1896 (Insecta, Hymenoptera, Braconidae). Bulletin of the Mizunami Fossil Museum, 33:125-126.

Collins, J.S.H., Mellish, C.J.T., Ross, A.J., Crabb, P.R., and Donovan, S.K. 2020. A guide to the fossil Decapoda (Crustacea: Axiidea, Anomura, Brachyura) of the British Isles. Proceedings of the Geologists' Association, 131:19-50. https://doi.org/10.1016/j.pgeola.2019.10.001

Crônier, C. and Boursicot, P.-Y. 2009. A new decapod crustacean faunule from the Middle Jurassic of north-west France. Palaeontology, 52:1275-1289. https://doi.org/10.1111/j.14754983.2009.00896.x

Dana, J.D. 1851. Crustacea Grapsoidea, (Cyclometopa, Edwardsii). Conspectus Crustaceorum quae in Orbis Terrarum circumnavigatione, Carolo Wilkes e Classe Reipublicae Foederatae duce, lexit et descripsit, 8. Proceedings of the Academy of Natural Sciences of Philadelphia, 5:247-254.

Dana, J.D. 1852. Parts I and II, Crustacea. U.S. Exploring Expedition during the Years 1838, 1839, 1840, 1841, 1842, under the Command of Charles Wilkes, U.S.N. 13:1-1618, 1 map; separate folio atlas with 96 pls.

Daniels, S.R., Cumberlidge, N., Pérez-Losada, M., Marijnissen, S.A.E., and Crandall, K.A. 2006. Evolution of Afrotropical freshwater crab lineages obscured by morphological convergence. Molecular Phylogenetics and Evolution, 40:227-235. https://doi.org/10.1016/ j.ympev.2006.02.022

Davidson, R.J. and Marsden, I.D. 1987. Size relationships and relative growth of the New Zealand swimming crab Ovalipes catharus (White, 1843). Journal of Crustacean Biology, 7:308-317. https://doi.org/10.1163/193724087X00261

Davie, P.J.F., Guinot, D., and Ng, P.K.L. 2015. Anatomy and functional morphology of Brachyura, p. 11-163. In Castro, P., Davie, P.J.F., Guinot, D., Schram, F.R., and von Vaupel Klein, J.C. (eds.), Treatise on Zoology-Anatomy, Taxonomy, Biology. The Crustacea, Volume 9 Part C (2 vols). Brill, Leiden. https://doi.org/10.1163/9789004190832_004 
De Haan, W. 1833. Crustacea, p. i-xvii, i-xxxi, ix-xvi, 1-243, pls. A-J, L-Q, 1-55, circ. table 2. In von Siebold, P.F. (ed.), Fauna Japonica sive Descriptio Animalium, quae in Itinere per Japoniam, Jussu et Auspiciis Superiorum, qui summum in India Batava Imperium Tenent, Suscepto, Annis 1823-1830 Collegit, Notis, Observationibus et Adumbrationibus Illustravit. J. Müller et Co., Lugduni Batavorum.

Dixon, C., Ahyong, S., and Schram, F. 2003. A new hypothesis of decapod phylogeny. Crustaceana, 76:935-975. https://doi.org/10.1163/156854003771997846

Étallon, A. 1861. Notes sur les Crustacés jurassiques du Bassin du Jura. Recueil agronomique, industriel et scientifique publié par la Société d'Agriculture de la Haute-Saône, 9:129-171.

Eudes-Deslongchamps, J.A. 1835. Mémoire pour servir à l'histoire naturelle des Crustacés fossils. Mémoire de la Societé Linnéenne de Normandie, 5:37-46, pl. 1.

Feldmann, R.M. 1993. Additions to the fossil decapod crustacean fauna of New Zealand. New Zealand Journal of Geology and Geophysics, 36:201-211. https://doi.org/10.1080/ 00288306.1993.9514568

Feldmann, R.M. and Schweitzer, C.E. 2009. Revision of Jurassic Homoloidea De Haan, 1839, from the Ernstbrunn and Štramberk limestones, Austria and the Czech Republic. Annalen des Naturhistorischen Museums in Wien, Serie A, 111:183-205.

Feldmann, R.M., Tshudy, D.M., and Thomson, M.R.A. 1993. Late Cretaceous and Paleocene decapod crustaceans from James Ross Basin, Antarctic Peninsula. The Paleontological Society Memoir, 28:1-41.

Feldmann, R.M., Lazăr, I., and Schweitzer, C.E. 2006. New crabs (Decapoda: Brachyura: Prosopidae) from Jurassic (Oxfordian) sponge bioherms of Dobrogea, Romania. Bulletin of the Mizunami Fossil Museum, 33:1-20.

Feldmann, R.M., Schweitzer, C.E., and Wahl, W.R. 2008. Ekalakia (Decapoda: Brachyura): the preservation of eyes links Cretaceous crabs to Jurassic ancestors. Journal of Paleontology, 82:1030-1034. https://doi.org/10.1666/08-006.1

Feldmann, R.M., Schweitzer, C.E., Schweigert, G., Robins, C., Karasawa, H., and Luque, J. 2016. Additions to the morphology of Munidopsidae (Decapoda: Anomura) and Goniodromitidae (Decapoda: Brachyura) from the Jurassic Solnhofen-type lagerstätten, Germany. Neues Jahrbuch für Geologie und Paläontologie-Abhandlungen, 279:43-56. https:/ /doi.org/10.1127/njgpa/2016/0539

Finney, W.C. and Abele, L.G. 1981. Allometric variation and sexual maturity in the obligate coral commensal Trapezia ferruginea Latreille (Decapoda, Xanthidae). Crustaceana, 41:113-130.

Förster, R. 1969. Epökie, Entökie, Parasitismus und Regeneration bei fossilen Dekapoden. Mitteilungen der Bayerischen Staatssammlung für Paläontologie und historische Geologie, 9:45-59.

Förster, R., Gaździcki, A., and Wrona, R. 1985. First record of a homolodromiid crab from a Lower Miocene glacio-marine sequence of West Antarctica. Neues Jahrbuch für Geologie und Paläontologie, Monatshefte, 1985:340-348.

Fraaije, R.H.B. 2014. Diverse Late Jurassic anomuran assemblages from the Swabian Alb and evolutionary history of paguroids based on carapace morphology. Neues Jahrbuch für Geologie und Paläontologie-Abhandlungen, 273:121-145. https://doi.org/10.1127/00777749/2014/0419

Fraaije, R.H.B., Van Bakel, B.W.M., Guinot, D., and Jagt, J.W.M. 2013. A new Middle Jurassic (Bajocian) homolodromioid crab from northwest France; the earliest record of the Tanidromitidae. Boletín de la Sociedad Geológica Mexicana, 65:249-254.

Fraaije, R.H.B., Van Bakel, B.W.M., Jagt, J.W.M., and Skupien, P. 2020. Paguroid anomurans from the upper Tithonian-lower Berriasian of Štramberk, Moravia (Czech Republic). Geologija 63:7-16. https://doi.org/10.5474/geologija.2020.001

Fraaye, R.H.B. 1996. Late Cretaceous swimming crabs: Radiation, migration, competition, and extinction. Acta Geologica Polonica, 46:269-278.

Franţescu, O.D. 2011. Brachyuran decapods (including five new species and one new genus) from Jurassic (Oxfordian-Kimmeridgian) coral reef limestones from Dobrogea, Romania. Neues Jahrbuch für Geologie und Paläontologie-Abhandlungen, 259:271-297. https:// doi.org/10.1127/0077-7749/2010/0110

Fratini, S., Vannini, M., Cannicci, S., and Schubart, C.D. 2005. Tree-climbing mangrove crabs: a case of convergent evolution. Evolutionary Ecology Research, 7:219-233.

Gemmellaro, G.G. 1869. Studi paleontologici sulla fauna del calcare à Terebratula janitor del Nord di Sicilia. Stabilimento Tipografico Lao, Palermo, Part 1:11-18, pls. 2, 3. 
Glaessner, M.F. 1933. Die Krabben der Juraformation. Zentralblatt für Mineralogie, Geologie und Paläontologie, Abteilung B, 1933:178-191.

Glaessner, M.F. 1969. Decapoda, R400-R533, R626-R628. In Moore, R.C. (ed.), Treatise on Invertebrate Paleontology, Part R, Arthropoda 4, vol. 1 \& 2. Geological Society of America and University of Kansas Press, Boulder, Colorado, and Lawrence, Kansas, 1-651.

Glaessner, M.F. 1980. New Cretaceous and Tertiary crabs (Crustacea: Brachyura) from Australia and New Zealand. Transactions of the Royal Society of South Australia, 104:171-192.

Gómez-Cruz, A. de J., Bermúdez, H.D., and Vega, F.J. 2015. A new species of Diaulax Bell, 1863 (Brachyura: Dialucidae) in the Early Cretaceous of the Rosablanca Formation, Colombia. Boletín de la Sociedad Geológica Mexicana, 67:103-112.

González-León, O., Ossó, À., Moreno-Bedmar, J.A., and Vega, F.J. 2016. Brachyura from the Lower Cretaceous (Aptian) of Spain: A new species of Rathbunopon (Homolodromioidea, Prosopidae) and the second record of Mithracites vectensis (Homoloidea). Neues Jahrbuch für Geologie und Paläontologie-Abhandlungen, 282:115-124. https://doi.org/10.1127/njgpa/ 2016/0608

Guinot, D. 1991. Éstablissement de la famille des Poupiniidae pour Poupinia hirsuta. gen. nov., sp. nov. de Polynésie (Crustacea Decapoda Brachyura Homoloidea). Bulletin du Muséum national d'Histoire naturelle, 12:577-605.

Guinot, D. 1995. Crustacea, Decapoda, Brachyura: Révision des Homolodromiidae Alcock, 1900. In Crosnier, A. (ed.), Résultats des Campagnes MUSORSTOM, volume 13. Mémoires du Muséum national d'Histoire naturelle (Paris), 163:155-282.

Guinot, D. 2019. New hypotheses concerning the earliest brachyurans (Crustacea, Decapoda, Brachyura). Geodiversitas 41:747-796.

Haworth, A.H. 1825. A new binary arrangement of the macrurous Crustacea. Philosophical Magazine and Journal, 65:183-184.

Hée, A. 1924. Catalogue critique des Crustacés jurassiques du Calvados et de l'Orne. Bulletin de la Societé Linnéenne de Normandie, (7)6:126-157, pls. 3-6.

Hyzný, M. and Müller, P.M. 2010. Loerenthopluma Beschin, Busulini, De Angeli \& Tessier, 1996 (Decapoda: Brachyura: Retroplumidae) from the Oligocene of Hungary. Atti della Società italiana di Scienze naturali e del Museo civico di Storia naturale in Milano, 151:123-134.

Hyžný, M. and Dulai, A. 2014. Deep-water fossorial shrimps from the Oligocene Kiscell Clay of Hungary: Taxonomy and palaeoecology. Acta Palaeontologica Polonica, 59:947-965. https:// doi.org/10.4202/app.2012.0078

Hyžný, M. and Zorn, I. 2016. A catalogue of the type and figured fossil decapod crustaceans in the collections of the Geological Survey of Austria in Vienna. Jahrbuch der Geologischen Bundesanstalt, 156:127-177.

Hyžný, M., Schlögl, J., and Krobicki, M. 2011. Tanidromites insignis (von Meyer, 1857) (Crustacea: Decapoda: Brachyura) from Late Jurassic non-biohermal facies of the Western Tethys (Pieniny Klippen Belt, Western Carpathians, Slovakia). Neues Jahrbuch für Geologie und Paläontologie-Abhandlungen, 262:213-226. https://doi.org/10.1127/0077-7749/2011/ 0193

Hyžný, M., Starzyk, N., Robins, C.M., and Kočová Veselská, M. 2015. Taxonomy and palaeoecology of a decapod crustacean assemblage from the Oxfordian of Stránská skála (Southern Moravia, Czech Republic). Bulletin of Geosciences, 90:633-650. https://doi.org/ 10.3140/bull.geosci.1559

Ilyin, I.V. 2005. Cretaceous and Paleogene Decapod Crustaceans of the Western Part of Northern Eurasia. State University Press, Moscow.

Jagt, J.W.M., Van Bakel, B.W.M., Fraaije, R.H.B., and Neumann, C. 2014. New data on midCretaceous dromioid crabs (Crustacea, Decapoda, Brachyura) from northwest Germany and southwest Iran. Scripta Geologica, 147:35-47.

Jakobsen, S.L. and Collins, J.S.H. 1997. New Middle Danian species of anomuran and brachyuran crabs from Fakse, Denmark. Bulletin of the Geological Society of Denmark, 44:89-100.

Karasawa, H. and Hirota, T. 2019. Two new species of Planoprosopon (Decapoda: Brachyura: Longodromitidae) from the Torinosu Group (Upper Jurassic-Lower Cretaceous), Shikoku, Japan. Bulletin of the Mizunami Fossil Museum, 45:27-32.

Karasawa, H., Kato, H., and Terabe, K. 2006. A new member of the family Prosopidae (Crustacea: Decapoda: Brachyura) from the Lower Cretaceous of Japan. Revista Mexicana de Ciencias Geológicas, 23:344-349. 
Karasawa, H., Schweitzer, C.E., and Feldmann, R.M. 2011. Phylogenetic analysis and revised classification of podotrematous Brachyura (Decapoda) including extinct and extant families. Journal of Crustacean Biology, 31:523-565. https://doi.org/10.1651/10-3423.1

Karasawa, H., Schweitzer, C.E., Feldmann, R.M., and Luque, J. 2014. Phylogeny and classification of Raninoida (Decapoda: Brachyura). Journal of Crustacean Biology, 34:216272. https://doi.org/10.1163/1937240X-00002216

Kato, H., Takahashi, T., and Taira, M. 2010. Late Jurassic decapod crustaceans from northeast Japan. Palaeontology, 53:761-770. https://doi.org/10.1111/j.1475-4983.2010.00960.x

Klompmaker, A.A. 2013a. Extreme diversity of decapod crustaceans from the mid-Cretaceous (late Albian) of Spain: implications for Cretaceous decapod paleoecology. Cretaceous Research, 41:150-185. https://doi.org/10.1016/j.cretres.2012.12.003

Klompmaker, A.A. 2013b. Revolutie, riffen en biodiversiteit: de opkomst van de Mesozoïsche tienpotigen. Gea, 46:117-118.

Klompmaker, A.A. 2016. Groot, groter, grootst: over krabben en kreeften in het Mesozoïcum. Gea, 49:43-44.

Klompmaker, A.A. and Boxshall, G.A. 2015. Fossil crustaceans as parasites and hosts. Advances in Parasitology, 90:233-289. https://doi.org/10.1016/bs.apar.2015.06.001

Klompmaker, A.A., Artal, P., and Gulisano, G. 2011. The Cretaceous crab Rathbunopon: revision, a new species and new localities. Neues Jahrbuch für Geologie und PaläontologieAbhandlungen, 260:191-202. https://doi.org/10.1127/0077-7749/2011/0170

Klompmaker, A.A., Feldmann, R.M., and Schweitzer, C.E. 2012. A hotspot for Cretaceous goniodromitids (Decapoda: Brachyura) from reef associated strata in Spain. Journal of Crustacean Biology, 32:780-801. https://doi.org/10.1163/193724012X635340

Klompmaker, A.A., Ortiz, J.D., and Wells, N.A. 2013a. How to explain a decapod crustacean diversity hotspot in a mid-Cretaceous coral reef. Palaeogeography, Palaeoclimatology, Palaeoecology, 374:256-273. https://doi.org/10.1016/j.palaeo.2013.01.024

Klompmaker, A.A., Schweitzer, C.E., Feldmann, R.M., and Kowalewski, M. 2013b. The influence of reefs on the rise of Mesozoic marine crustaceans. Geology, 41:1179-1182. https://doi.org/ 10.1130/G34768.1

Klompmaker, A.A., Artal, P., Van Bakel, B.W.M., Fraaije, R.H.B., and Jagt, J.W.M. 2014. Parasites in the fossil record: a Cretaceous fauna with isopod-infested decapod crustaceans, infestation patterns through time, and a new ichnotaxon. PLoS One, 9:e92551. https:// doi.org/10.1371/journal.pone.0092551

Klompmaker, A.A., Schweitzer, C.E., Feldmann, R.M., and Kowalewski, M. 2015a. Environmental and scale-dependent evolutionary trends in the body size of crustaceans. Proceedings of the Royal Society B: Biological Sciences, 282:20150440. https://doi.org/ 10.1098/rspb.2015.0440

Klompmaker, A.A., Portell, R.W., Klier, A.T., Prueter, V., and Tucker, A.L. 2015b. Spider crabs of the Western Atlantic with special reference to fossil and some modern Mithracidae. PeerJ, 3:e1301. https://doi.org/10.7717/peerj.1301

Klompmaker, A.A., Hyžný, M., and Jakobsen, S.L. 2015c. Taphonomy of decapod crustacean cuticle and its effect on the appearance as exemplified by new and known taxa from the Cretaceous-Danian crab Caloxanthus. Cretaceous Research, 55:141-151. https://doi.org/ 10.1016/j.cretres.2014.11.011

Klompmaker, A.A., Portell, R.W., and Frick, M.G. 2017. Comparative experimental taphonomy of eight marine arthropods indicates distinct differences in preservation potential. Palaeontology, 60:773-794. https://doi.org/10.1111/pala.12314

Klompmaker, A.A., Hyžný, M., Portell, R.W., Jauvion, C., Charbonnier, S., Fussell, S.S., Klier, A.T., Tejera, R., and Jakobsen, S.L. 2019. Muscles and muscle scars in fossil malacostracan crustaceans. Earth-Science Reviews, 194:306-326. https://doi.org/10.1016/ j.earscirev.2019.04.012

Krobicki, M. and Zatoń, M. 2008. Middle and Late Jurassic roots of brachyuran crabs: Palaeoenvironmental distribution during their early evolution. Palaeogeography, Palaeoclimatology, Palaeoecology, 263:30-43. https://doi.org/10.1016/j.palaeo.2008.01.025

Krobicki, M. and Zatoń, M. 2016. A new homolodromioid crab (Brachyura: Dromiacea: Tanidromitidae) from the Bajocian of central Poland and a review of the stratigraphical distribution and paleoenvironments of the known Middle Jurassic homolodromioids. Journal of Crustacean Biology, 36:695-715. https://doi.org/10.1163/1937240X-00002463 
Kuhn, O. 1936. Neue Decapoden aus dem fränkischen Jura. Zentralblatt für Mineralogie, Geologie und Paläontologie, Abteilung B, 1936:120-128.

Kuhn, O. 1939. Beiträge zur Fauna des Oxford und Kimmeridge in Nordbayern. Neues Jahrbuch für Mineralogie, Geologie und Paläontologie, Beilage-Bände, (B), 80:464-497.

Latreille, P.A. 1802. Histoire naturelle, générale et particulière, des Crustacés et des Insectes, v. 3. F. Dufart, Paris.

Latreille, P.A. 1825. Entomologie, ou histoire naturelle des Crustacés, des Arachnides et des Insectes, p. 1-832. Genre de Crustacés. Encyclopédie méthodique, (Histoire naturelle), 10. Agasse Imprimeur-Libraire, Paris.

Leinfelder, R.R., Schmid, D.U., Nose, M., and Werner, W. 2002. Jurassic reef patterns-the expression of a changing globe, p. 465-520. In Kiessling, W., Flügel, E., and Golonka, J. (eds.), Phanerozoic Reef Patterns. SEPM Special Publication, Tulsa.

Lemaitre, R. and Tavares, M. 2014. New morphological and distributional information on Homolodromiidae and Homolidae (Decapoda: Brachyura) from the Americas, with description of a new species and comments on western Pacific species. Journal of Crustacean Biology, 34:504-524. https://doi.org/10.1163/1937240X-00002243

Linnaeus, C. 1758. Systema Naturae per Regna tria Naturae, secundum classes, ordines, genera, species, cum characteribus, differentiis, synonymis, locis (ed. 10), vol 1. Laurentii Salvii, Holmiae.

López-Horgue, M.A. and Bodego, A. 2017. Mesozoic and Cenozoic decapod crustaceans from the Basque-Cantabrian basin (Western Pyrenees): new occurrences and faunal turnovers in the context of basin evolution. Bulletin de la Société géologique de France, 188:14. https:// doi.org/10.1051/bsgf/2017180

Lőrenthey, E. and Beurlen, K. 1929. Die fossilen Decapoden der Länder der Ungarischen Krone. Geologica Hungarica, (Palaeontologica), 3:1-421, 12 tables, 16 pls.

Luque, J., Schweitzer, C.E., Santana, W., Portell, R.W., Vega, F.J., and Klompmaker, A.A. 2017. Checklist of fossil decapod crustaceans from tropical America. Part I: Anomura and Brachyura. Nauplius, 25:e2017025. https://doi.org/10.1590/2358-2936e2017025

Luque, J., Feldmann, R.M., Vernygora, O., Schweitzer, C.E., Cameron, C.B., Kerr, K.A., Vega, F.J., Duque, A., Strange, M., Palmer, A.R., and Jaramillo, C. 2019. Exceptional preservation of mid-Cretaceous marine arthropods and the evolution of novel forms via heterochrony. Science Advances, 5:eaav3875. https://doi.org/10.1126/sciadv.aav3875

MacLeay, W.S. 1838. On the brachyurous decapod Crustacea brought from the Cape by Dr. Smith, p. 53-71, 2 pls. In Smith, A. (ed.), Illustrations of the Annulosa of South Africa; consisting chiefly of figures and descriptions of the objects of natural history collected during an expedition into the interior of South Africa, in the years 1834, 1835, and 1836; fitted out by "The Cape of Good Hope Association for Exploring Central Africa. . ." Smith, Elder and Company, London.

Manning, R.B. and Felder, D.L. 1991. Revision of the American Callianassidae (Crustacea: Decapoda: Thalassinidea). Proceedings of the Biological Society of Washington, 104:764792.

Martin, J.W. 1990. Crabs of the family Homolodromiidae, II. Dicranodromia felderi, new species, from the Western Atlantic, with notes on the type series of $D$. ovata A. Milne Edwards, 1880. Journal of Crustacean Biology, 10:708-720. https://doi.org/10.2307/1548415

Martin, J.W., Christiansen, J.C., and Trautwein, S.E. 2001. Crabs of the family Homolodromiidae, VI. Homolodromia monstrosa new species (Decapoda: Brachyura) from the western North Atlantic with a redescription of the holotype of Homolodromia paradoxa A. Milne Edwards, 1880 and comments on sexual dimorphism. Bulletin of Marine Science, 68:313-326.

Maury, J.C. 1930. O Cretaceo da Parahyba do Norte. Ministerio da Agricultura, Industria e Commercio, Serviço Geologico e Mineralogico do Brasil, Monographia, 8:1-305.

McLaughlin, P.A. and Lemaitre, R. 1997. Carcinization in the Anomura-fact or fiction? I. Evidence from adult morphology. Contributions to Zoology, 67:79-123. https://doi.org/10.1163/ 18759866-06702001

M'Coy, F. 1849. XIX.- On the classification of some British fossil Crustacea, with notices of new forms in the University Collection at Cambridge. Annals and Magazine of Natural History, 4:161-179. https://doi.org/10.1080/03745486009494810

Meyer, R.K. and Schmidt-Kaler, H. 1983. Erdgeschichte sichtbar gemacht. Ein geologischer Führer durch die Altmühlal. Bayerisches Geologisches Landesamt, München. 
Milne Edwards, A. 1865. Note sur deux nouveaux Crustacés fossiles du terrain néocomien du Département de l'Yonne. Bulletin de la Société des Sciences Historiques et Naturelles de l'Yonne, 19:341-347, pl. 5.

Moericke, W. 1889. Die Crustaceen der Stramberger Schichten. Palaeontographica, Supplement 2, 6:43-72, pl. 6.

Moore, J. and Willmer, P. 1997. Convergent evolution in invertebrates. Biological Reviews, 72:160.

Müller, P., Krobicki, M., and Wehner, G. 2000. Jurassic and Cretaceous primitive crabs of the family Prosopidae (Decapoda: Brachyura)-their taxonomy, ecology and biogeography. Annales Societatis Geologorum Poloniae, 70:49-79.

Negreiros-Fransozo, M.L., Colpo, K.D., and Costa, T.M. 2003. Allometric growth in the fiddler crab Uca thayeri (Brachyura, Ocypodidae) from a subtropical mangrove. Journal of Crustacean Biology, 23:273-279. https://doi.org/10.1651/02780372(2003)023[0273:AGITFC]2.0.CO;2

Néraudeau, D., Perrichot, V., Batten, D.J., Boura, A., Girard, V., Jeanneau, L., Nohra, Y.A., Polette, F., Martin, S.S., Saint Martin, J.-P., and Thomas, R. 2017. Upper Cretaceous amber from Vendée, north-western France: Age dating and geological, chemical, and palaeontological characteristics. Cretaceous Research, 70:77-95. https://doi.org/10.1016/ j.cretres.2016.10.001

Ng, P.K.L. and McLay, C.L. 2005. Dicranodromia danielae, a new species of homolodromiid crab from the Philippines (Crustacea: Decapoda: Brachyura). Zootaxa, 1029:39-46. https:// doi.org/10.11646/zootaxa.1029.1.3

Nyborg, T., Garassino, A., Vega, F.J., and Kovalchuk, G. 2019. Fossil decapod crustaceans from the Early Cretaceous (Albian) of Oregon, USA. Neues Jahrbuch für Geologie und Paläontologie-Abhandlungen, 293:127-138. https://doi.org/10.1127/njgpa/2019/0836

Ossó, À., Van Bakel, B., Ferratges-Kwekel, F.A., and Moreno-Bedmar, J.A. 2018. A new decapod crustacean assemblage from the lower Aptian of La Cova del Vidre (Baix Ebre, province of Tarragona, Catalonia). Cretaceous Research, 92:94-107. https://doi.org/10.1016/ j.cretres.2018.07.011

Patrulius, D. 1959. Contributions à la systématique des décapodes néojurassiques. Revue de Géologie et Géographie, 3:249-257.

Patrulius, D. 1966. Les Décapodes du Tithonique Inférieur de Woźniki (Carpates Polonaises Occidentales). Annales de la Société Géologique de Pologne, 36:495-517, pls. 30, 31.

Pennant, T. 1777. British Zoology, vol. IV. Crustacea. Mollusca. Testacea. B. White, London.

Pérez-Losada, M., Høeg, J.T., and Crandall, K.A. 2009. Remarkable convergent evolution in specialized parasitic Thecostraca (Crustacea). BMC Biology, 7:15. https://doi.org/10.1186/ 1741-7007-7-15

Quenstedt, F.A. 1858. Der Jura. Verlag der H. Lauppschen Buchhandlung, Tübingen.

Quenstedt, F.A. 1867. Handbuch der Petrefaktenkunde. H. Laupp, Tübingen.

Remeš, M. 1895. Beiträge zur Kenntnis der Crustaceen der Stramberger Schichten. Bulletin international de l'Académie des Sciences de Bohême, 2:200-204, pls. 1-3.

Reuss, A. 1859. Zur Kenntnis fossiler Krabben. Denkschriften der kaiserlichen Akademie der Wissenschaften Wien, 17:1-90.

Reuss, A.E. 1858. Über kurzschwänzige Krebse im Jurakalke Mährens. Sitzungsberichte der Kaiserlichen Akademie der Wissenschaften, (Mathematisch-naturwissenschaftliche Classe), 31:5-13.

Robin, N., Van Bakel, B.W.M., d'Hondt, J.-L., and Charbonnier, S. 2015. A new early brachyuran (Crustacea, Decapoda) from the Middle Jurassic of northwest France, epibionts and ecological considerations. Contributions to Zoology, 84:179-191. https://doi.org/10.1163/ 18759866-08403001

Robin, N., Van Bakel, B.W.M., Hyžný, M., Cincotta, A., Garcia, G., Charbonnier, S., Godefroit, P., and Valentin, X. 2019. The oldest freshwater crabs: claws on dinosaur bones. Scientific Reports, 9:20220. https://doi.org/10.1038/s41598-019-56180-w

Robins, C.M., Feldmann, R.M., and Schweitzer, C.E. 2013. Nine new genera and 24 new species of the Munidopsidae (Decapoda: Anomura: Galatheoidea) from the Jurassic Ernstbrunn Limestone of Austria, and notes on fossil munidopsid classification. Annalen des Naturhistorischen Museums in Wien, Serie A, 115:167-251. 
Robins, C.M., Feldmann, R.M., Schweitzer, C.E., and Bonde, A. 2016. New families Paragalatheidae and Catillogalatheidae (Decapoda: Anomura: Galatheoidea) from the Mesozoic, restriction of the genus Paragalathea, and establishment of 6 new genera and 20 new species. Annalen des Naturhistorischen Museums in Wien, Serie A, 118:65-131.

Robins, C.M. and Klompmaker, A.A. 2019. Extreme diversity and parasitism of Late Jurassic squat lobsters (Decapoda: Galatheoidea) and the oldest records of porcellanids and galatheids. Zoological Journal of the Linnean Society, 187:1131-1154. https://doi.org/ 10.1093/zoolinnean/zlz067

Samouelle, G. 1819. The Entomologist's Useful Compendium, or an Introduction to the British Insects, etc. T. Boys, London.

Schädel, M., Perrichot, V., and Haug, J.T. 2019. Exceptionally preserved cryptoniscium larvaemorphological details of rare isopod crustaceans from French Cretaceous Vendean amber. Palaeontologia Electronica, 22.3.71:1-46. https://doi.org/10.26879/977 https://palaeo-electronica.org/content/2019/2757-cretaceous-epicaridea

Schneider, S., Harzhauser, M., Kroh, A., Lukeneder, A., and Zuschin, M. 2013. Ernstbrunn Limestone and Klentnice beds (Kimmeridgian Berriasian; Waschberg-dánice Unit; NE Austria and SE Czech Republic): state of the art and bibliography. Bulletin of Geosciences, 88:105-130.

Scholtz, G. 2014. Evolution of crabs-history and deconstruction of a prime example of convergence. Contributions to Zoology, 83:87-105.

Schweigert, G. 2019. The Upper Kimmeridgian limestones of Saal an der Donau (Bavaria, Germany)-the most diverse Late Jurassic crustacean fauna of a coral reef in Germany. 7th Symposium on Mesozoic and Cenozoic Decapod Crustaceans-Book of Abstracts, Ljubljana, p. 21-22.

Schweigert, G. and Koppka, J. 2011. Decapods (Crustacea: Brachyura) from the Jurassic of Germany and Lithuania, with descriptions of new species of Planoprosopon and Tanidromites. Neues Jahrbuch für Geologie und Paläontologie-Abhandlungen, 260:221-235. https://doi.org/10.1127/0077-7749/2011/0136

Schweigert, G. and Kuschel, H. 2018. Schwäbische und Fränkische Albein Paradies für JuraKrabben. Fossilien, 4/2018:14-23.

Schweigert, G., Kuschel, H., and Scherzinger, A. 2016. Following the steps of Hermann v. Meyer: a newly collection brachyuran fauna from Late Jurassic sponge-microbial limestones near Geislingen an der Steige, SW Germany. 6th Symposium on Mesozoic and Cenozoic Decapod Crustaceans, Viller-sur-Mer, p. 63-64.

Schweitzer, C.E. and Feldmann, R.M. 2008a. A new classification for some Jurassic Brachyura (Crustacea: Decapoda: Brachyura: Homolodromioidea): families Goniodromitidae Beurlen, 1932 and Tanidromitidae new family. Senckenbergiana lethaea, 87:119-155. https://doi.org/ 10.1007/BF03043911

Schweitzer, C.E. and Feldmann, R.M. 2008b. Revision of the genus Laeviprosopon Glaessner, 1933 (Decapoda: Brachyura: Homolodromioidea: Prosopidae) including two new species. Neues Jahrbuch für Geologie und Paläontologie-Abhandlungen, 250:273-285. https:// doi.org/10.1127/0077-7749/2008/0250-0273

Schweitzer, C.E. and Feldmann, R.M. 2009a. New species of Longodromitidae Schweitzer and Feldmann, 2009, from the Ernstbrunn Formation, Late Jurassic (Tithonian), Austria. Annalen des Naturhistorischen Museums in Wien. Serie A, 111:207-223.

Schweitzer, C.E. and Feldmann, R.M. 2009b. Revision of Gabriella Collins et al., 2006 (Decapoda: Brachyura: Homolodromioidea: Tanidromitidae) with new Jurassic species. Neues Jahrbuch für Geologie und Paläontologie-Abhandlungen, 252:1-16. https://doi.org/ 10.1127/0077-7749/2009/0252-0001

Schweitzer, C.E. and Feldmann, R.M. 2009c. Revision of the genus Cyclothyreus Remeš, 1895 (Decapoda: Brachyura: Dromioidea). Neues Jahrbuch für Geologie und PaläontologieAbhandlungen, 253:357-372.

Schweitzer, C.E. and Feldmann, R.M. 2009d. Revision of the Prosopinae sensu Glaessner, 1969 (Crustacea: Decapoda: Brachyura) including four new families, four new genera, and five new species. Annalen des Naturhistorischen Museums in Wien, Serie A, 110:55-121.

Schweitzer, C.E. and Feldmann, R.M. 2010a. A new family of Mesozoic Brachyura (Glaessneropsoidea) and reevaluation of Distefania Checchia-Rispoli, 1917 (Homolodromioidea: Goniodromitidae). Neues Jahrbuch für Geologie und PaläontologieAbhandlungen, 256:363-380. https://doi.org/10.1127/0077-7749/2010/0059 
Schweitzer, C.E. and Feldmann, R.M. 2010b. Revision of Cycloprosopon and additional notes on Eodromites (Brachyura: Homolodromioidea: Goniodromitidae). Annalen des Naturhistorischen Museums in Wien. Serie A, 112:169-194.

Schweitzer, C.E. and Feldmann, R.M. 2010c. The genus Coelopus Étallon, 1861 (Brachyura: Glaessneropsoidea: Longodromitidae) with new species. Neues Jahrbuch für Geologie und Paläontologie-Abhandlungen, 258:51-60. https://doi.org/10.1127/0077-7749/2010/0084

Schweitzer, C.E. and Feldmann, R.M. 2010d. The oldest Brachyura (Decapoda: Homolodromioidea: Glaessneropsoidea) known to date (Jurassic). Journal of Crustacean Biology, 30:251-256. https://doi.org/10.1651/09-3231.1

Schweitzer, C.E. and Feldmann, R.M. 2015. Faunal turnover and niche stability in marine Decapoda in the Phanerozoic. Journal of Crustacean Biology, 35:633-649. https://doi.org/ 10.1163/1937240X-00002359

Schweitzer, C.E. and Feldmann, R.M. 2016. Species of Decapoda (Crustacea) in the fossil record: patterns, problems, and progress, p. 278-300. In Allmon, W.D. and Yacobucci, M.M. (eds.), Species and Speciation in the Fossil Record. University of Chicago Press, Chicago.

Schweitzer, C.E., Feldmann, R.M., Franţescu, O.D., and Klompmaker, A. 2012a. Revision of Etyidae Guinot and Tavares, 2001 (Crustacea: Brachyura). Journal of Paleontology, 86:129155. https://doi.org/10.1666/11-060.1

Schweitzer, C.E., Feldmann, R.M., Garassino, A., Karasawa, H., and Schweigert, G. 2010. Systematic list of fossil decapod crustacean species. Crustaceana Monographs, 10:1-222.

Schweitzer, C.E., Feldmann, R.M., and Karasawa, H. 2012b. Part R, Revised, Volume 1, Chapter 8M: Systematic descriptions: Infraorder Brachyura, Section Dromiacea. Treatise Online, 51:1-43. https://doi.org/10.17161/to.v0i0.4336

Schweitzer, C.E., Feldmann, R.M., Lazăr, I., Schweigert, G., and Franţescu, O.D. 2018. Decapoda (Anomura; Brachyura) from the Late Jurassic of the Carpathians, Romania. Neues Jahrbuch für Geologie und Paläontologie-Abhandlungen, 288:307-341. https:// doi.org/10.1127/njgpa/2018/0744

Schweitzer, C.E., Feldmann, R.M., and Lazăr, I.R. 2007a. Decapods from Jurassic (Oxfordian) sponge megafacies of Dobrogea, Romania and reconsideration of Nodoprosopon Beurlen, 1928. Neues Jahrbuch für Geologie und Paläontologie-Abhandlungen, 244:99-113. https:// doi.org/10.1127/0077-7749/2007/0244-0099

Schweitzer, C.E., Feldmann, R.M., Phillips, G.E., and Armstrong, A. 2019. Cretaceous Decapoda (Crustacea) from Mississippi, USA. Neues Jahrbuch für Geologie und Paläontologie-Abhandlungen, 293:145-197. https://doi.org/10.1127/njgpa/2019/0838

Schweitzer, C.E., Lazăr, I., Feldmann, R.M., Stoica, M., and Franţescu, O. 2017. Decapoda (Anomura; Brachyura) from the Late Jurassic of Dobrogea, Romania. Neues Jahrbuch für Geologie und Paläontologie-Abhandlungen, 286:207-228. https://doi.org/10.1127/njgpa/ 2017/0696

Schweitzer, C.E., Nyborg, T.G., Feldmann, R.M., and Ross, R.L.M. 2004. Homolidae de Haan, 1839 and Homolodromiidae Alcock, 1900 (Crustacea: Decapoda: Brachyura) from the Pacific Northwest of North America and a reassessment of their fossil records. Journal of Paleontology, 78:133-149. https://doi.org/10.1666/00223360(2004)078<0133:HDHAHA>2.0.CO;2

Schweitzer, C.E., Van Bakel, B., Karasawa, H., Artal, P., and Jagt, J.W.M. 2007b. Revision of the genus Titanocarcinus (Decapoda: Brachyura: Xanthoidea) with two new genera and one new species. Journal of Crustacean Biology, 27:278-295. https://doi.org/10.1651/S-2713.1

Serrano-Sánchez, M. de L., Nagler, C., Haug, C., Haug, J.T., Centeno-García, E., and Vega, F.J. 2016. The first fossil record of larval stages of parasitic isopods: cryptoniscus larvae preserved in Miocene amber. Neues Jahrbuch für Geologie und PaläontologieAbhandlungen, 279:97-106. https://doi.org/10.1127/njgpa/2016/0543

Shirk, A.M. 2006. A Novel Assemblage of Decapod Crustacea, from a Tithonian Coral Reef Olistolith, Purcareni, Romania: Systematical Arrangement and Biogeographical Perspective. MS Thesis. Kent State University, Kent, Ohio, USA. https://etd.ohiolink.edu/ pg_10?0::NO:10:P10_ACCESSION_NUM:kent1163901231

Starzyk, N. 2013. Jurassic crabs: new characters of carapace diagnostic to known tanidromitid species. Neues Jahrbuch für Geologie und Paläontologie-Abhandlungen, 269:173-187. https://doi.org/10.1127/0077-7749/2013/0343 
Starzyk, N. 2015a. New species of the genus Tanidromites (Decapoda: Brachyura:

Tanidromitidae) from the Oxfordian of Poland. Acta Zoologica Cracoviensia, 58:129-136. https://doi.org/10.3409/azc.58_2.129

Starzyk, N. 2015b. Reappraisal of the primitive crab Eodromites, with description of three new species from European localities (Decapoda: Brachyura: Goniodromitidae). Palaeontologia Electronica, 18.3.50A:1-19. https://doi.org/10.26879/513 https://palaeo-electronica.org/content/2015/1345-the-crab-eodromites

Starzyk, N. 2016. Three new species of the genus Tanidromites (Decapoda: Brachyura: Tanidromitidae) from the Late Jurassic (Oxfordian) of Poland. Palaeontologia Electronica, 19.3.45A:1-14. https://doi.org/10.26879/619 https://palaeo-electronica.org/content/2016/1660-new-species-of-tanidromites

Starzyk, N. 2020. The oldest species of the genus Laeviprosopon (Decapoda: Brachyura: Prosopidae) from the Oxfordian of Poland. Acta Zoologica Cracoviensia, 63:9-13. https:// doi.org/10.3409/azc.63.02

Starzyk, N., Krzemińska, E., and Krzemiński, W. 2011. Intraspecific variation in the Jurassic crab Bucculentum bucculentum (Decapoda: Homolodromioidea: Bucculentidae). Neues Jahrbuch für Geologie und Paläontologie-Abhandlungen, 260:203-210. https://doi.org/10.1127/00777749/2011/0169

Stenzel, H.B. 1945. Decapod crustaceans from the Cretaceous of Texas. University of Texas Publications, 4401:401-476.

Stolley, E. 1924. Über einige Krebsreste aus schweizerischem und norddeutschem Neokom. Eclogae geologicae Helvetiae, 18:411-429.

Tshudy, D., Robles, R., Chan, T.-Y., Ho, K.C., Chu, K.H., Ahyong, S.T., and Felder, D.L. 2009. Phylogeny of marine clawed lobster families Nephropidae Dana, 1852, and Thaumastochelidae Bate, 1888, based on mitochondrial genes, p. 357-368. In Martin, J.W., Crandall, K.A., and Felder, D.L. (eds.), Decapod Crustacean Phylogenetics. Crustacean Issues 18. CRC Press, Boca Raton.

Tshudy, D. and Sorhannus, U. 2000. Pectinate claws in decapod crustaceans: Convergence in four lineages. Journal of Paleontology, 74:474-486. https://doi.org/10.1017/ S0022336000031735

Van Bakel, B.W.M., Guinot, D., Artal, P., Fraaije, R.H.B., and Jagt, J.W.M. 2012. A revision of the Palaeocorystoidea and the phylogeny of raninoidian crabs (Crustacea, Decapoda, Brachyura, Podotremata). Zootaxa, 3215:1-216.

Van Straelen, V. 1925. Contribution à l'étude des Crustacés Décapodes de la période jurassique. Mémoires d'Académie Royale de Belgique, Science, Ser. 2, 7:1-462, pls. 1-10.

Van Straelen, V. 1936. Crustacés Décapodes nouveaux ou peu connus de l'époque Crétacique. Bulletin du Musée royal d'Histoire naturelle de Belgique, 12:1-49.

Van Straelen, V. 1944. Anomure et Brachyures du Cénomanien de la Navarre. Bulletin du Musée Royal d'Histoire Naturelle de Belgique, 20:1-12, pl. 1.

Vašíček, Z. and Skupien, P. 2016. Tithonian-early Berriasian perisphinctoid ammonites from the Štramberk Limestone at Kotouč Quarry near Štramberk, Outer Western Carpathians (Czech Republic). Cretaceous Research, 64:12-29. https://doi.org/10.1016/j.cretres.2016.03.005

Vašíček, Z., Skupien, P., and Jagt, J.W.M. 2018. Current knowledge of ammonite assemblages from the Štramberk Limestone (Tithonian-lower Berriasian) at Kotouč Quarry, Outer Western Carpathians (Czech Republic). Cretaceous Research, 90:185-203. https://doi.org/10.1016/ j.cretres.2018.04.016

Vega, F.J., Feldmann, R.M., García-Barrera, P., Filkorn, H., Pimentel, F., and Avendaño, J. 2001. Maastrichtian Crustacea (Brachyura: Decapoda) from the Ocozocuautla Formation in Chiapas, southeast Mexico. Journal of Paleontology, 75:319-329. https://doi.org/10.1017/ S0022336000018126

Vega, F.J., Phillips, G.E., Nyborg, T., Flores-Ventura, J., Clements, D., Espinosa, B., and SolísPichardo, G. 2013. Morphology and size variation of a portunoid crab from the Maastrichtian of the Americas. Journal of South American Earth Sciences, 47:116-135. https://doi.org/ 10.1016/j.jsames.2013.07.005

von Meyer, H. 1835. Briefliche Mittheilungen. Neues Jahrbuch für Mineralogie, Geologie, Geognosie und Petrefaktenkunde, 1835:329.

von Meyer, H. 1840. Neue Gattungen fossiler Krebse aus Gebilden vom bunten Sandsteine bis in die Kreide. E. Schweizerbart, Stuttgart. 
von Meyer, H. 1842. Ueber die in dem dichten gelben Jurakalk von Aalen in Würtemberg vorkommenden Species des Crustaceengenus Prosopon. Beiträge zur Petrefaktenkunde, 5:70-75, pl. 15.

von Meyer, H. 1856. Briefliche Mittheilungen. Jahrbuch für Mineralogie, Geologie, Geognosie und Petrefaktenkunde, 1856:51.

von Meyer, H. 1857. Briefliche Mittheilungen. Neues Jahrbuch für Mineralogie, Geognosie, Geologie und Petrefaktenkunde, 1857:556.

von Meyer, H. 1858. Briefliche Mittheilungen. Neues Jahrbuch für Mineralogie, Geognosie, Geologie und Petrefaktenkunde, 1858:59-62.

von Meyer, H. 1860. Die Prosoponiden oder die Familie der Maskenkrebse. Palaeontographica, 7:183-222, pl. 23.

Wehner, G. 1988. Über die Prosoponiden (Crustacea, Decapoda) des Jura. Dissertation. Ludwig-Maximilians-Universität München, Munich, Germany.

Wienberg Rasmussen, H., Jakobsen, S.L., and Collins, J.S.H. 2008. Raninidae infested by parasitic Isopoda (Epicaridea). Bulletin of the Mizunami Fossil Museum, 34:31-49.

Williams, J.D. and Boyko, C.B. 2012. The global diversity of parasitic isopods associated with crustacean hosts (Isopoda: Bopyroidea and Cryptoniscoidea). PLoS One, 7:e35350. https:// doi.org/10.1371/journal.pone.0035350

Withers, T.H. 1945. LVI.-New Cretaceous cirripedes and crab. Annals and Magazine of Natural History, 12:552-561. https://doi.org/10.1080/00222934508654759

Withers, T.H. 1951. Some Jurassic and Cretaceous crabs (Prosoponidae). Bulletin of the British Museum (Natural History) (Geology), 1:171-192.

Wolfe, J.M., Breinholt, J.W., Crandall, K.A., Lemmon, A.R., Lemmon, E.M., Timm, L.E., Siddall, M.E., and Bracken-Grissom, H.D. 2019. A phylogenomic framework, evolutionary timeline and genomic resources for comparative studies of decapod crustaceans. Proceedings of the Royal Society B: Biological Sciences, 286:20190079. https://doi.org/10.1098/rspb.2019.0079

Wood-Mason, J. 1875. On the genus Deidamia Willemoes-Smith. Annals and Magazine of Natural History, (4) 15:131-135.

Woodward, H. 1868. II.-On a new brachyurous crustacean (Prosopon mammillatum), from the Great Oolite, Stonesfield. Geological Magazine, 5:3-5. https://doi.org/10.1017/ S0016756800207140

Woodward, H. 1907. V.-On a new brachyurous crustacean from the "Clypeus-Grit" (Inferior Oolite) of the Cotteswold Hills. Geological Magazine, 4:79-81. https://doi.org/10.1017/ S0016756800120205

Wright, C.W. and Collins, J.S.H. 1972. British Cretaceous crabs. Palaeontographical Society Monographs, 126:1-113. 


\section{APPENDIX 1.}

Comparison of the sizes and length-width ratios and another ratio of Eodromites spp.

\begin{tabular}{|c|c|c|c|c|c|c|}
\hline Specimen & $\begin{array}{l}\text { Length } \\
(\mathrm{mm})\end{array}$ & $\begin{array}{c}\text { Width } \\
(\mathrm{mm})\end{array}$ & L/W & 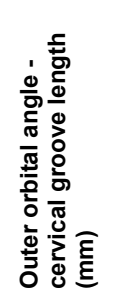 & 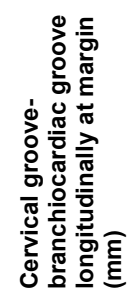 & 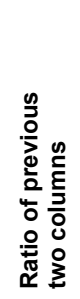 \\
\hline $\begin{array}{l}\text { Eodromites bernchrisdomiorum sp. nov., I-F/MP/3526/ } \\
\text { 1533/08 }\end{array}$ & 8.7 & 8.1 & 1.07 & 1.57 & 2.25 & 0.70 \\
\hline E. bernchrisdomiorum sp. nov., I-F/MP/3604/1533/08 & 10.3 & 9.8 & 1.05 & 1.76 & 2.55 & 0.69 \\
\hline E. bernchrisdomiorum sp. nov., I-F/MP/4927/1534/09 & & 7.2 & & 1.31 & 1.9 & 0.69 \\
\hline E. bernchrisdomiorum sp. nov., I-F/MP/6255/1588/11 & & 7.9 & & 1.37 & 2.03 & 0.67 \\
\hline E. bernchrisdomiorum sp. nov., I-F/MP/6258/1588/11 & & 4.2 & & 0.77 & 1.04 & 0.74 \\
\hline E. bernchrisdomiorum sp. nov., I-F/MP/6259/1588/11 & 10.2 & 9.3 & 1.10 & 1.52 & 2.45 & 0.62 \\
\hline E. cristinarobinsae sp. nov., MAB k2951 & 14 & 13.6 & 1.03 & 2.4 & 2.6 & 0.92 \\
\hline E. cristinarobinsae sp. nov., MAB k2952 & 7.3 & 7.3 & 1.00 & 1.6 & 1.9 & 0.84 \\
\hline E. cristinarobinsae sp. nov., MAB k2640 & 4.7 & 4.5 & 1.04 & 1.1 & 1.25 & 0.88 \\
\hline E. depressus, BSP-1983 I 210 & & & & & & 0.88 \\
\hline E. dobrogea, LPBIIlart-040 & & 20.4 & & 3.8 & 5.1 & 0.75 \\
\hline E. dobrogea, LPBIII art 070 & 20.3 & 20.3 & 1.00 & 5.1 & 6.3 & 0.81 \\
\hline E. dobrogea, NHMW 1990/0041/2812 & 9.7 & 9.6 & 1.01 & 1.8 & 2.4 & 0.75 \\
\hline E. dobrogea, NHMW 1990/0041/0095 & & 8.3 & & 1.7 & 2 & 0.85 \\
\hline E. grandis, NHMW 1990/0041/3073 & 9 & 8.1 & 1.11 & 2.26 & 2.37 & 0.95 \\
\hline E. grandis, NHMW 1990/0041/3328 & 13.6 & 11.8 & 1.15 & 3.06 & 3.63 & 0.84 \\
\hline E. grandis, BSP-1881 IX 678 & 11.3 & 10.2 & 1.11 & 2.46 & 3.03 & 0.81 \\
\hline E. grandis, LPBIII art 243 & & 7.06 & & 1.81 & 1.86 & 0.97 \\
\hline E. nitidus & & & & & & 0.69 \\
\hline E. polyphemi, MGUP-020.18 & & 32.2 & & 0.66 & 0.77 & 0.86 \\
\hline E. rostratus & & & & & & 0.62 \\
\hline E. rotundus, I-F/MP/6270/1599/12 & & 2.4 & & 0.47 & 0.58 & 0.81 \\
\hline E. rotundus, I-F/MP/3992/1533/08 & 2.87 & 2.48 & 1.16 & 0.51 & 0.57 & 0.89 \\
\hline
\end{tabular}




\section{APPENDIX 2.}

Comparison of the sizes and length-width ratios of Eodromites cristinarobinsae sp. nov. and $E$. grandis.

\begin{tabular}{|c|c|c|c|c|c|c|}
\hline Specimen & Age & 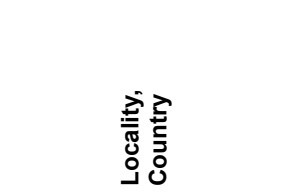 & 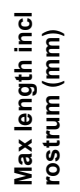 & 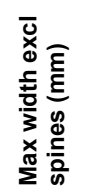 & 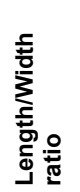 & Reference \\
\hline $\begin{array}{l}\text { Eodromites cristinarobinsae sp. nov. (MAB } \\
\text { k2951) }\end{array}$ & Albian & Koskobilo, Spain & 9.4 & 9.1 & 1.03 & new measurement \\
\hline E. cristinarobinsae sp. nov. (MAB k2952) & Albian & Koskobilo, Spain & 7.2 & 7.1 & 1.01 & new measurement \\
\hline E. cristinarobinsae sp. nov. (UF 271883) & Albian & Koskobilo, Spain & 5.2 & 4.8 & 1.08 & new measurement \\
\hline E. cristinarobinsae sp. nov. (UF 271792) & Albian & Koskobilo, Spain & 5 & 4.7 & 1.06 & new measurement \\
\hline E. cristinarobinsae sp. nov. (MAB k2953) & Albian & Koskobilo, Spain & 4.3 & 4 & 1.08 & new measurement \\
\hline E. grandis (NHMW 1990/0041/3073) & Tithonian & near Dörfles, Austria & 9 & 8.1 & 1.11 & new measurement \\
\hline E. grandis (NHMW 2017/0089/0040) & Tithonian & near Dörfles, Austria & 12.1 & 10.6 & 1.14 & new measurement \\
\hline E. grandis (NHMW 1990/0041/3328) & Tithonian & near Dörfles, Austria & 13.2 & 12 & 1.10 & new measurement \\
\hline E. grandis (NHMW 1990/0041/5186) & Tithonian & near Dörfles, Austria & 17.8 & 16.2 & 1.10 & new measurement \\
\hline E. grandis (NHMW 1990/0041/3237) & Tithonian & near Dörfles, Austria & 12.8 & 11.3 & 1.13 & new measurement \\
\hline E. grandis (NHMW 1990/0041/3334) & Tithonian & near Dörfles, Austria & 15.9 & 14.55 & 1.09 & new measurement \\
\hline E. grandis (NHMW 2007z0149/0052) & Tithonian & near Dörfles, Austria & 19.5 & 18 & 1.08 & $\begin{array}{l}\text { Schweitzer \& } \\
\text { Feldmann (2010, fig. } \\
5.2)\end{array}$ \\
\hline E. grandis (BSP 1881 IX 678, neotype) & Kimmeridgian & Örlinger Tal, Germany & 11.6 & 10.5 & 1.10 & $\begin{array}{l}\text { Schweitzer \& } \\
\text { Feldmann (2008, pl. } \\
\text { 4F) }\end{array}$ \\
\hline E. grandis (LPBIII art 242) & $\begin{array}{l}\text { Oxfordian- } \\
\text { Kimmeridgian }\end{array}$ & $\begin{array}{l}\text { Waypoint 160, } \\
\text { Romania }\end{array}$ & 7.5 & 6.7 & 1.12 & $\begin{array}{l}\text { Schweitzer et al. } \\
(2017 \text {, fig. } 6.1)\end{array}$ \\
\hline
\end{tabular}




\section{APPENDIX 3.}

Comparison of carapace ratios of Europrosopon aculeatum and E. verrucosum.

\begin{tabular}{|c|c|c|}
\hline & 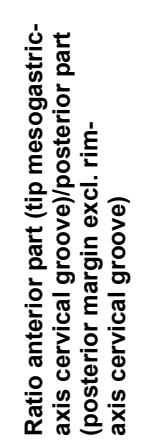 & 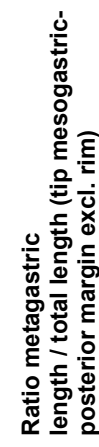 \\
\hline GBA 2007/096/0003 (=GSA 2360), holotype Europrosopon verrucosum & 0.48 & 0.16 \\
\hline NHMW 2007/0149/0005, E. verrucosum & 0.51 & 0.15 \\
\hline Bachmayer (1964: fig. 130), E. verrucosum & 0.55 & 0.13 \\
\hline UF 288714, Klompmaker (2016: fig. 2 left), E. verrucosum & 0.66 & 0.14 \\
\hline NHMW/1990 0041/4059, E. verrucosum & 0.60 & 0.14 \\
\hline NHMW 2007z0149/0005, E. verrucosum & 0.53 & 0.14 \\
\hline Wehner (1988: pl. 1.1), neotype E. aculeatum & 0.49 & 0.15 \\
\hline SNSB-BSPG 2016 XXI 496, Wehner (1988: pl. 1.2), E. aculeatum & 0.58 & 0.15 \\
\hline
\end{tabular}




\section{APPENDIX 4.}

Comparison of carapace sizes and length-width ratios of Europrosopon spp.

\begin{tabular}{|c|c|c|c|c|c|c|}
\hline Specimen & $\begin{array}{c}\text { Prior } \\
\text { identification }\end{array}$ & Reference & 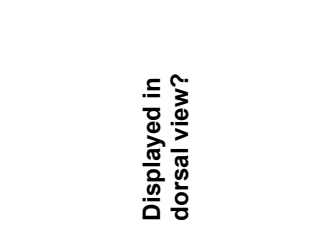 & 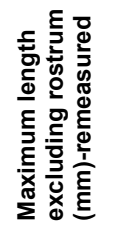 & 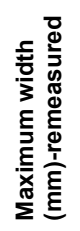 & 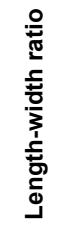 \\
\hline $\begin{array}{l}\text { NHMW 1990/0041/ } \\
0033\end{array}$ & $\begin{array}{l}\text { "Prosopon" } \\
\text { verrucosum }\end{array}$ & Schweitzer \& Feldmann (2009) & & 5.5 & 4.8 & 1.15 \\
\hline 1990/0041/0034 & P. verrucosum & Schweitzer \& Feldmann (2009) & & 7.4 & 5.8 & 1.28 \\
\hline $1990 / 0041 / 2110$ & P. verrucosum & & & 7.3 & 6.2 & 1.18 \\
\hline $1990 / 0041 / 2516$ & P. verrucosum & Schweitzer \& Feldmann (2009) & & 5.7 & 4.7 & 1.21 \\
\hline $1990 / 0041 / 2520$ & P. verrucosum & Schweitzer \& Feldmann (2009) & & 8.2 & 7.3 & 1.12 \\
\hline $1990 / 0041 / 3071$ & P. verrucosum & & & 4.4 & 3.6 & 1.22 \\
\hline $1990 / 0041 / 3756$ & P. verrucosum & Schweitzer \& Feldmann (2009) & & 4.5 & 3.5 & 1.29 \\
\hline $1990 / 0041 / 3961$ & P. verrucosum & Schweitzer \& Feldmann (2009) & & 9.6 & 8.2 & 1.17 \\
\hline $1990 / 0041 / 4059$ & P. verrucosum & Schweitzer \& Feldmann (2009) & & 7.9 & 6.4 & 1.23 \\
\hline $1990 / 0041 / 4908$ & P. verrucosum & Schweitzer \& Feldmann (2009) & & 2.1 & 1.8 & 1.17 \\
\hline $2007 z 0149 / 0003$ & P. verrucosum & Schweitzer \& Feldmann (2009) & & 14.6 & 13.7 & 1.07 \\
\hline $2007 z 0149 / 0004$ & P. verrucosum & Schweitzer \& Feldmann (2009) & $\begin{array}{l}\text { Schweitzer \& Feldmann } \\
\text { (2009: fig. 2.11, as } \\
\text { 2007z0149/0005) }\end{array}$ & 14.4 & 12.7 & 1.13 \\
\hline $2007 z 0149 / 0005$ & P. verrucosum & Schweitzer \& Feldmann (2009) & & 6.5 & 5.8 & 1.12 \\
\hline $\begin{array}{l}\text { GBA 2007/096/0003 } \\
(=\text { GBA 2360) }\end{array}$ & $\begin{array}{l}P . \text { verrucosum, } \\
\text { holotype }\end{array}$ & $\begin{array}{l}\text { Schweitzer \& Feldmann (2009), } \\
\text { Hyžný \& Zorn (2016) }\end{array}$ & $\begin{array}{l}\text { Schweitzer \& Feldmann } \\
\text { (2009: fig. 2.7), Hyžný \& } \\
\text { Zorn (2016: pl. 2.7a) }\end{array}$ & 14.8 & 12.9 & 1.15 \\
\hline UF 288714 & P. verrucosum & Klompmaker $(2013,2016)$ & & 4 & 3.5 & 1.14 \\
\hline UF 288756 & P. verrucosum & & & 4.4 & 3.6 & 1.22 \\
\hline LPBIII art 278 & P. barbulescuae & Schweitzer et al. (2018) & $\begin{array}{l}\text { Schweitzer et al. (2018: } \\
\text { fig. 13.1) }\end{array}$ & 6.05 & 5.2 & 1.16 \\
\hline LPBIII art 279 & P. barbulescuae & Schweitzer et al. (2018) & $\begin{array}{l}\text { Schweitzer et al. (2018: } \\
\text { fig. 13.2) }\end{array}$ & 4.2 & 3.7 & 1.14 \\
\hline $\begin{array}{l}\text { Museum Tübingen, } \\
\text { specimen in } \\
\text { Quenstedt, 1858, pl. } \\
95.34 .\end{array}$ & $\begin{array}{l}P \text {. aculeatum, } \\
\text { neotype }\end{array}$ & $\begin{array}{l}\text { Wehner (1988), Schweitzer \& } \\
\text { Feldmann (2009) }\end{array}$ & $\begin{array}{l}\text { Wehner (1988: pl. 1.1), } \\
\text { Schweitzer \& Feldmann } \\
\text { (2009: fig. 2.10) }\end{array}$ & 8.95 & 8.1 & 1.10 \\
\hline $\begin{array}{l}\text { SNSB-BSPG } 2016 \\
\text { XXI } 496\end{array}$ & $P$. aculeatum & Wehner (1988) & Wehner (1988: pl. 1.2) & 8.75 & 7.7 & 1.14 \\
\hline
\end{tabular}

